\title{
Brookfield Homes Passive House Performance Evaluation
}

A. Herk, A. Poerschke, and R. Beach IBACOS, Inc.

February 2016 


\section{NOTICE}

This report was prepared as an account of work sponsored by an agency of the United States government. Neither the United States government nor any agency thereof, nor any of their employees, subcontractors, or affiliated partners makes any warranty, express or implied, or assumes any legal liability or responsibility for the accuracy, completeness, or usefulness of any information, apparatus, product, or process disclosed, or represents that its use would not infringe privately owned rights. Reference herein to any specific commercial product, process, or service by trade name, trademark, manufacturer, or otherwise does not necessarily constitute or imply its endorsement, recommendation, or favoring by the United States government or any agency thereof. The views and opinions of authors expressed herein do not necessarily state or reflect those of the United States government or any agency thereof.

Available electronically at SciTech Connect http:/www.osti.gov/scitech

Available for a processing fee to U.S. Department of Energy and its contractors, in paper, from:

U.S. Department of Energy

Office of Scientific and Technical Information

P.O. Box 62

Oak Ridge, TN 37831-0062

OSTI http://www.osti.gov

Phone: 865.576.8401

Fax: 865.576.5728

Email: reports@osti.gov

Available for sale to the public, in paper, from:

U.S. Department of Commerce

National Technical Information Service

5301 Shawnee Road

Alexandria, VA 22312

NTIS http://www.ntis.gov

Phone: 800.553 .6847 or 703.605 .6000

Fax: 703.605.6900

Email: orders@ntis.gov 


\title{
Brookfield Homes Passive House Performance Evaluation
}

\author{
Prepared for:
}

The National Renewable Energy Laboratory

On behalf of the U.S. Department of Energy's Building America Program

Office of Energy Efficiency and Renewable Energy

15013 Denver West Parkway

Golden, CO 80401

NREL Contract No. DE-AC36-08GO28308

Prepared by:

A. Herk, A. Poerschke, and R. Beach

IBACOS, Inc.

2214 Liberty Avenue

Pittsburgh, PA 15222

NREL Technical Monitor: Stacey Rothgeb

Prepared under Subcontract No. KNDJ-0-40341-05

February 2016 
The work presented in this report does not represent performance of any product relative to regulated minimum efficiency requirements.

The laboratory and/or field sites used for this work are not certified rating test facilities. The conditions and methods under which products were characterized for this work differ from standard rating conditions, as described.

Because the methods and conditions differ, the reported results are not comparable to rated product performance and should only be used to estimate performance under the measured conditions. 


\section{Contents}

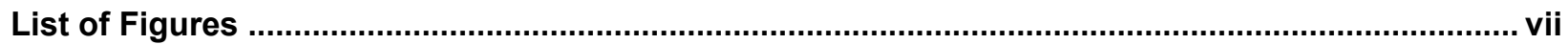

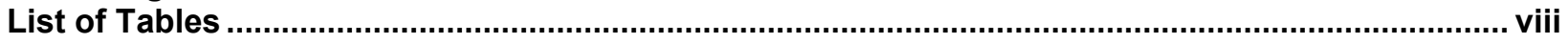

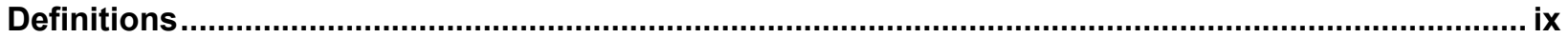

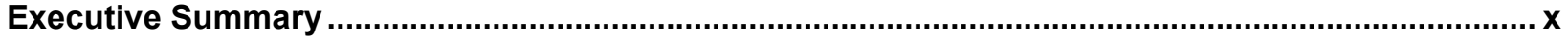

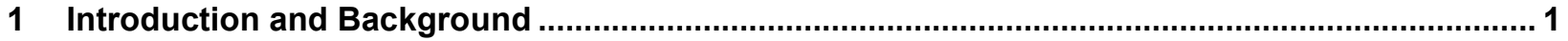

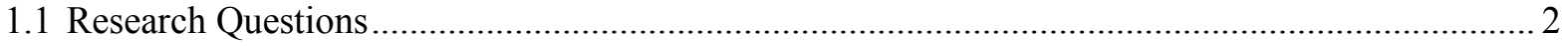

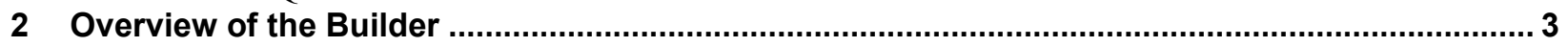

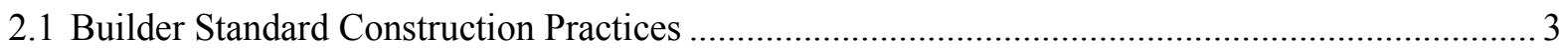

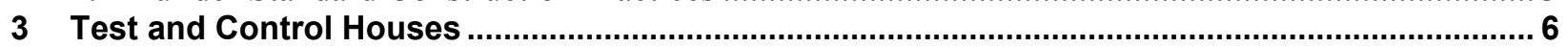

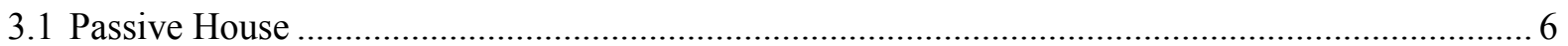

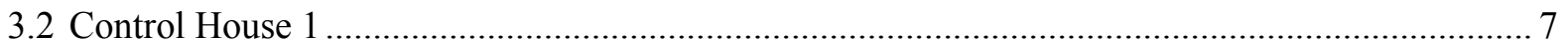

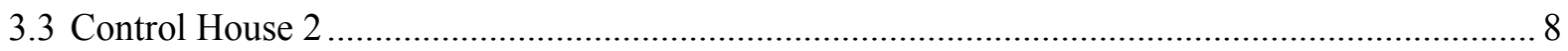

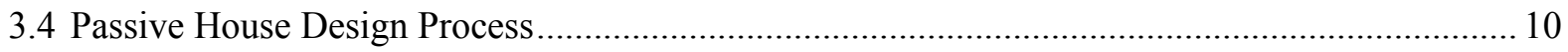

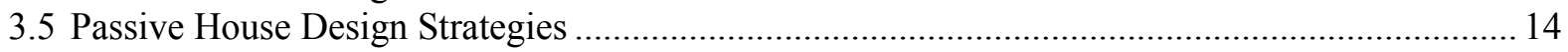

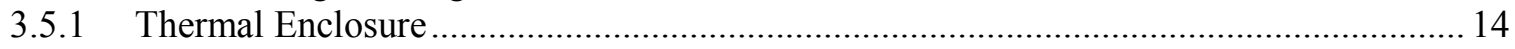

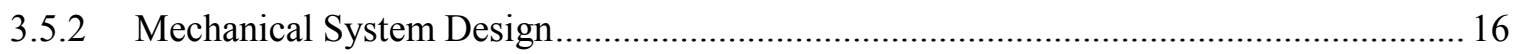

3.6 Zero Energy Ready Home Program Compliance .............................................................. 17

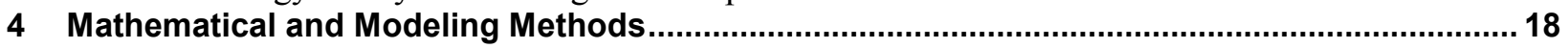

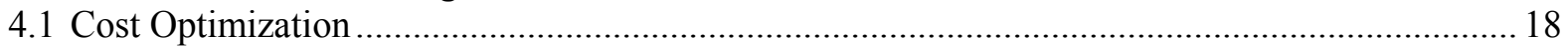

4.2 Air Conditioning Contractors of America Manual J and Manual D ............................................ 19

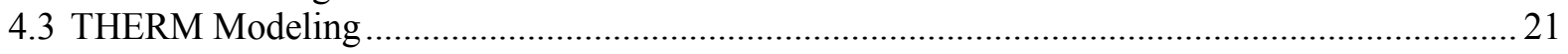

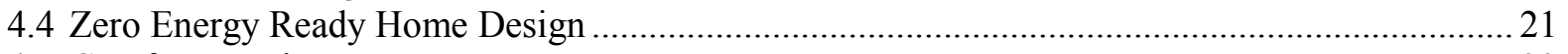

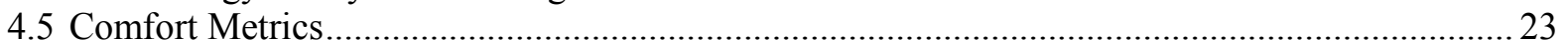

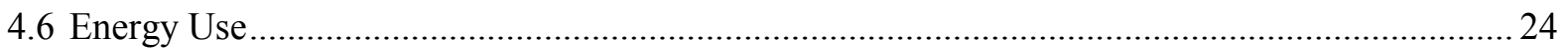

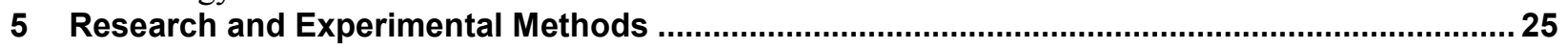

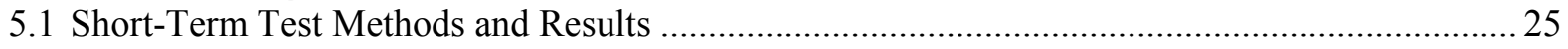

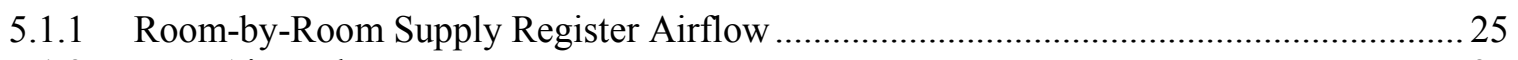

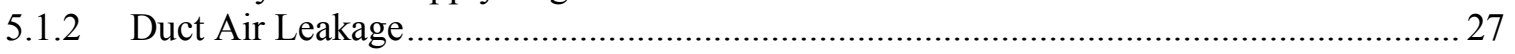

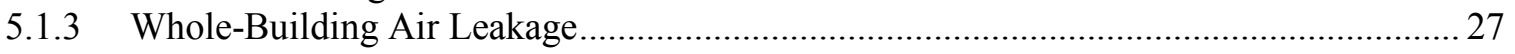

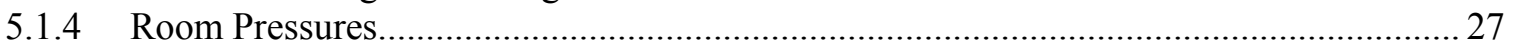

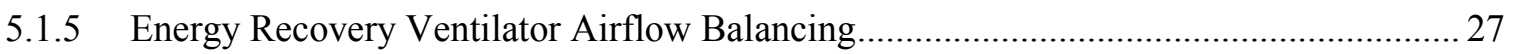

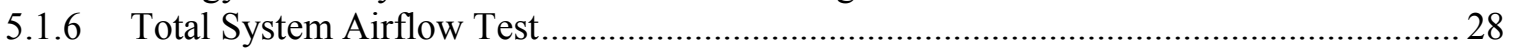

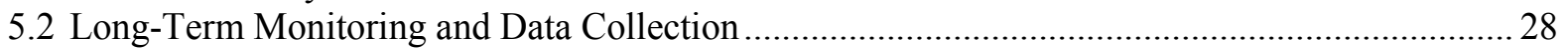

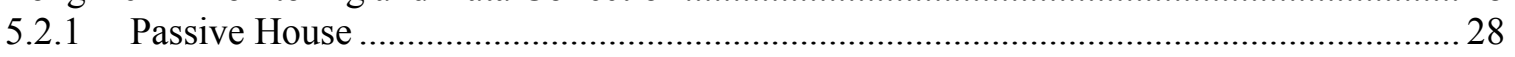

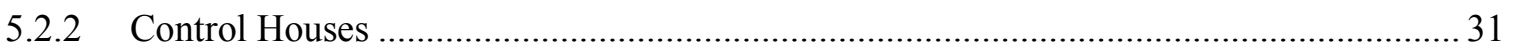

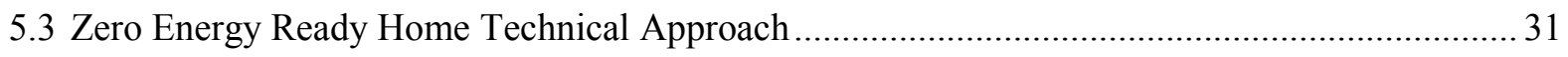

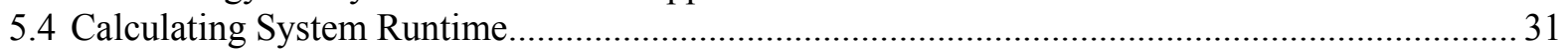

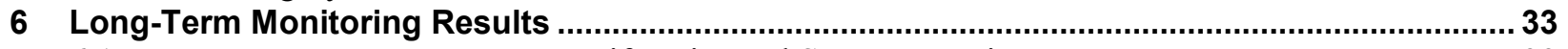

6.1 Room-to-Room Temperature Uniformity and System Runtime............................................... 33

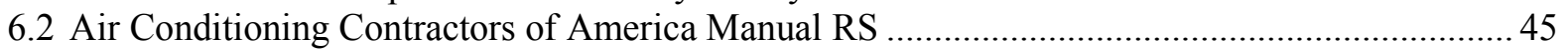

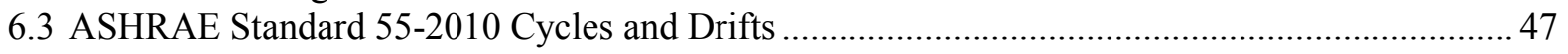

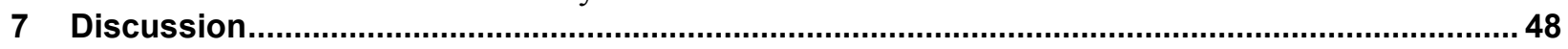

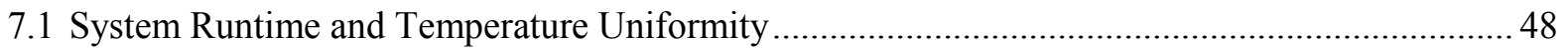

7.2 Air Conditioning Contractors of America Room-to-Thermostat Temperature Uniformity-

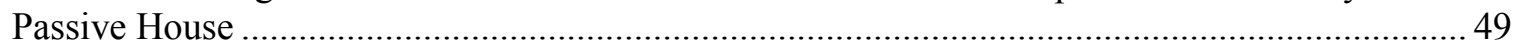

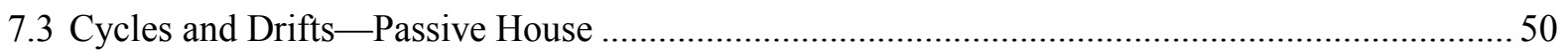

7.4 Passive House Design and Construction Process Results ......................................................... 50

7.5 Zero Energy Ready Home Design Results ..................................................................... 52

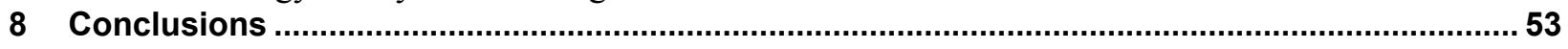

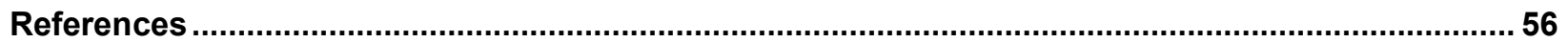


Appendix A: Standard Package versus Passive House Package.................................................. 57

Appendix B: Full Drawing Set of the Passive House .................................................................... 60

Appendix C: Contractor Air Conditioning Contractors of America Manual J and Manual D

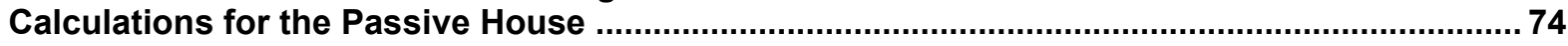

Appendix D: Monitoring System Design for the Passive House................................................... 77

Appendix E: IBACOS Air Conditioning Contractors of America Manual J Calculations for the

Passive House 


\section{List of Figures}

Figure 1. Location map (left) and site plan (right) of Brookfield's Midtown community in Denver ... 3

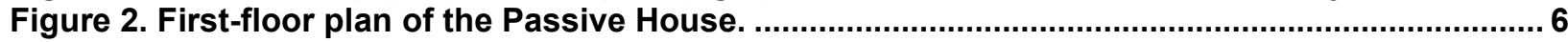

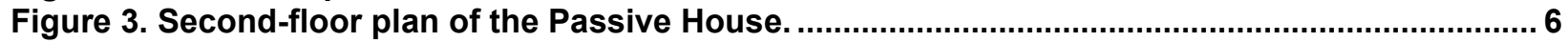

Figure 4. Front and side elevations of the Passive House …............................................................ 7

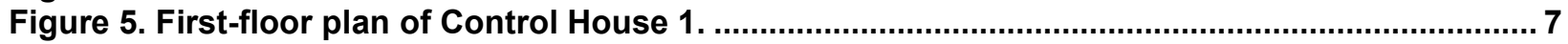

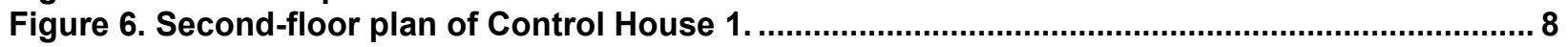

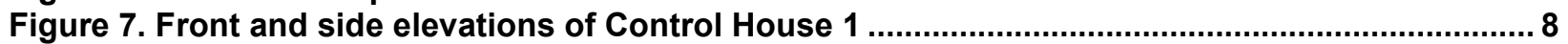

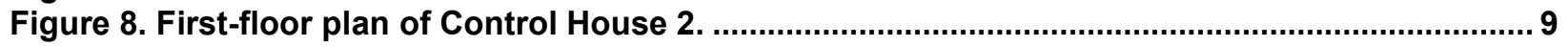

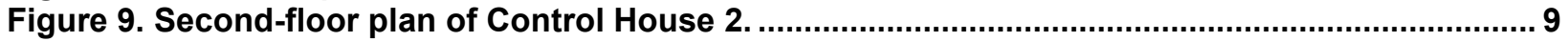

Figure 10. Front elevation of Control House 2 ......................................................................... 10

Figure 11. First-floor plan comparison-early schematic (left) to final (right).................................11

Figure 12. Second-floor plan comparison-early schematic (left) to final (right)............................12

Figure 13. First-floor (left) and second-floor (right) plans showing shear bracing........................... 13

Figure 14. Schematic design elevations show the window layout................................................ 14

Figure 15. Final design elevations show the window layout. Note the differences in window

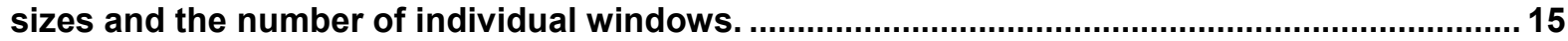

Figure 16. Test house (Passive House) (far left) and other production houses in Midtown............. 15

Figure 17. Mechanical closet with the air handling unit and water heater (left) and the

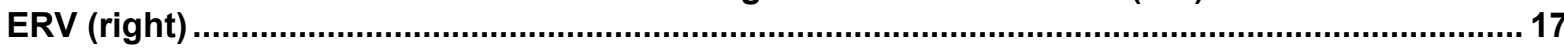

Figure 18. Builder's standard practice (Control House 1 and Control House 2) compared to various Passive House components and the BEopt Reference House ...................................... 19

Figure 19. HVAC layout from ACCA Manual D at the basement of the

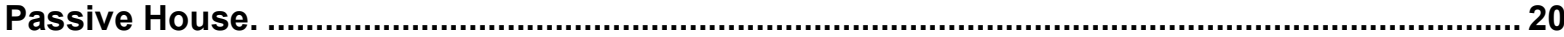

Figure 20. HVAC layout from ACCA Manual D at the first floor of the Passive House......................20

Figure 21. HVAC layout from ACCA Manual D at the second floor of the Passive House................21

Figure 22. Heat flux and construction of slab-on-grade to foundation wall detail............................21

Figure 23. Diagram showing example ACCA Manual RS and drift/ramp failures .............................24

Figure 24. DG-700 used to measure total system airflow ........................................................... 28

Figure 25. Data logging control center in the basement of the Passive House .............................. 29

Figure 26. Wireless temperature and relative humidity sensor location on the second floor

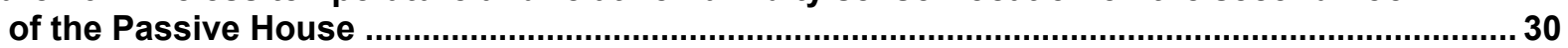

Figure 27. ERV sensor location in the second-floor mechanical closet of the Passive House......... 30

Figure 28. Calculated runtime of HVAC equipment highlighted in white.......................................... 32

Figure 29. Outdoor temperature and solar irradiance at the test site for the cooling period ............ 33

Figure 30. Outdoor temperature and solar irradiance at the test site for the heating period ............ 33

Figure 31. Daily average room-to-room temperature differences versus outdoor

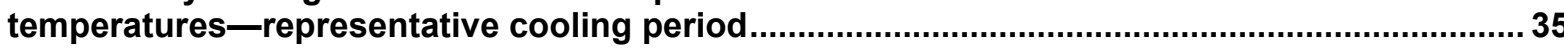

Figure 32. Daily average room-to-room temperature differences versus outdoor temperatures-representative heating period......................................................................... 36

Figure 33. Passive House-cooling mode-room temperatures and system operation ...................37

Figure 34. Control House 1-cooling mode-room temperatures and system operation ................. 38

Figure 35. Control House 2-cooling mode-room temperatures and system operation ................ 39

Figure 36. Passive House-heating mode-room temperatures and system operation ................... 40

Figure 37. Control House 1-heating mode-room temperatures and system operation ................ 41

Figure 38. Control House 2-heating mode-room temperatures and system operation ................. 42

Figure 39. Heat map of system runtime-cooling mode...................................................................... 43

Figure 40. Heat map of thermostat temperature - cooling mode ......................................................... 43

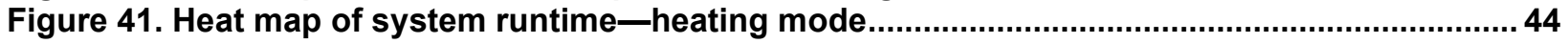

Figure 42. Heat map of thermostat temperature-heating mode ......................................................... 44

Figure 43. Temperature difference between the master bedroom and thermostat-

Figure 44 . Temperature difference between the master bedroom and thermostatheating mode 
Figure 45. Passive House-room-to-thermostat temperature difference 46

Figure 46. Sensor layout in the basement.

Figure 47. Sensor layout in the first floor. 78

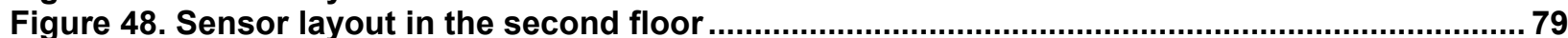

Figure 49. Sensor layout on the HVAC system. 80

Unless otherwise noted, all figures and photos were created by IBACOS.

\section{List of Tables}

Table 1. Specification Packages for the Builder's Standard Product and the Passive House 5

Table 2. Specifications for the Builder's Standard for the 4420 Floor Plan in Brighton Heights ..... 22

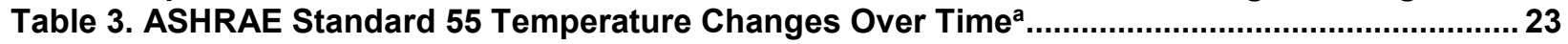

Table 4. Room-by-Room Supply Register Airflows in the Passive House ....................................... 26

Table 5. Final Whole-House Air Leakage for the Passive House ................................................... 27

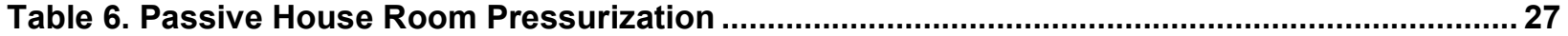

Table 7. Total System Airflow Measurements for the Control Houses ............................................ 28

Table 8. Daily Room-to-Room Temperature Difference Statistics-Cooling ( $\left.{ }^{\circ} \mathrm{F}\right)$.............................. 34

Table 9. Daily Room-to-Room Temperature Difference Statistics-Heating ( $\left.{ }^{\circ} \mathrm{F}\right)$............................... 35

Table 10. Percentage of Time a Room Was Outside ACCA Thermal Uniformity Guidelines

(Passive House)

Table 11. Total Count of ASHRAE Standard 55-2010 Cycle or Drift Occurrences .............................47

Table 12. Peak Heating and Cooling Loads, by Floor as Calculated by IBACOS............................ 52

Table 13. Specifications for the Builder's Standard Product and the Passive House..................... 57

Table 14. Long-Term Monitoring Equipment Installed in the Passive House................................... 81

Unless otherwise noted, all tables were created by IBACOS. 


\section{Definitions}

$\begin{array}{ll}\text { ACCA } & \text { Air Conditioning Contractors of America } \\ \text { AFUE } & \text { Annual Fuel Utilization Efficiency } \\ \text { BEopt } & \text { Building Energy Optimization (software) } \\ \text { Btu/h } & \text { British Thermal Unit per Hour } \\ \text { ccSPF } & \text { Closed-Cell Spray Polyurethane Foam } \\ \text { CFM } & \text { Cubic Feet per Minute } \\ \text { DOE } & \text { U.S. Department of Energy } \\ \text { ERV } & \text { Energy Recovery Ventilator } \\ \text { GI } & \text { Residential Energy Services Network Insulation Installation } \\ \text { Grade I } \\ \text { HERS } & \text { Home Energy Rating System } \\ \text { HVAC } & \text { Heating, Ventilating, and Air Conditioning } \\ \text { PHPP } & \text { Passive House Planning Package } \\ \text { ZERH } & \text { Zero Energy Ready Home }\end{array}$




\section{Executive Summary}

Brookfield Residential Colorado (Brookfield) has begun a new homebuilding division in a community called Midtown that is approximately 4 miles north of downtown Denver. ${ }^{1}$ Brookfield plans to have its standard production homes, which are based on the model homes, achieve a Home Energy Rating System Index of 45 to 55 and to be ENERGY STAR ${ }^{\circledR}$ Version 3 certified. This performance is notably higher than currently offered by many production builders in the area.

To further define its market position with high-performance homebuilding, Brookfield worked with the U.S. Department of Energy Building America research team IBACOS to design and construct a Certified Passive House ${ }^{2}$ as a model home to evaluate advanced building technologies and to use as a marketing tool for potential homebuyers. A summary of the design process is presented.

Brookfield selected KGA|studio architects to design the Passive House; the intent was to offer the plan as a standard production model. Brookfield constructed the house to the Certified Passive House standards and plans to offer the Passive House performance as an upgrade option. Construction began in March 2013, and the house was completed and certified in August 2013. This Certified Passive House was the first constructed in the United States by a production homebuilder, and it was the first by any builder in Colorado. In the same time frame and in the same Midtown area, Brookfield also built two homes as "control homes" for comparative testing; these feature the builder's standard energy package. The control home floor plans differ slightly from those of the Passive House but have similar square footage.

IBACOS worked with Brookfield to identify a package of energy-efficiency measures that would achieve Passive House certification and could be implemented in an occupied test house. Shortterm performance testing in the Passive House was done during and after the construction period. Limited short-term testing was performed in the control houses.

Since the Passive House was certified, IBACOS and the National Renewable Energy Laboratory have undertaken long-term monitoring of the whole-house comfort conditions and performance. Long-term monitoring equipment also was installed in the two control homes. IBACOS monitored the three homes from August 2014 through April 2015 to compare collected performance data. Results showed that the Passive House provided better room-to-room temperature uniformity than the control houses. The monitored data also showed that the thermostat location in the Passive House may have contributed to perimeter space overheating because the controlling temperature sensor did not recognize solar heat gains. The ductwork geometry and the occupants' inability to seasonally rebalance the delivered room airflows also contributed to floor-to-floor stratification. A number of issues with attempted energy measurements at the Passive House negated the opportunity to provide monitored energy use comparisons between the Passive House construction and the builder's standard package.

\footnotetext{
${ }^{1}$ Brookfield Homes' Midtown community, www.hellomidtown.com/.

${ }^{2}$ www.phaus.org/learn/passive-house-education/what-is-passive-house-.
} 
An important outcome of the research effort was the advent of heat maps as a means to identify, indicate, quantify, and assess the degree to which a home and its comfort systems provide comfort.

A construction cost evaluation is presented based on the builder's estimated costs. For a base plan that typically would be set at a selling price of $\$ 469,000$, the estimated additional cost to build the Passive House is $\$ 85,000$, or $18.1 \%$ of the base price. The Passive House was listed at $\$ 569,000$, but it sold for $\$ 529,000$. The actual sale price did not cover the builder's investment in its first Passive House. A cost-optimization process shows that building to Passive House standards is a costly venture - one that is far removed from an optimized point from mortgaged first-cost and energy-cost standpoints.

In a companion effort, IBACOS also helped Brookfield conceptualize home designs for Denver's Brighton Heights area, where Brookfield was considering building to Zero Energy Ready Home standards. IBACOS provided strategies that Brookfield can use if it chooses to pursue a Zero Energy Ready Home plan for that market in the future. 


\section{Introduction and Background}

When evaluating the next level of home energy efficiency to bring to market, production homebuilders are seeking information and experience that provide insights into the Passive House concept developed by the Passive House Institute US. "Passive building cuts energy consumption by $60-80$ percent compared to code buildings. Certified passive buildings provide superior comfort, indoor air quality, and resilience." 3 This project meets the builders' needs by exploring the incremental costs associated with a production builder achieving Passive House Institute US Passive House Certification in a cold climate, documenting the design and engineering process, and evaluating the energy and comfort performance of a test house.

In late 2012, Brookfield Residential Colorado (Brookfield) started a production building operation in the Denver market and broke ground on model homes at Midtown, a community approximately 4 miles north of downtown. Although this was a start-up division, each Brookfield management team member had experience building highly energy-efficient homes in a production environment. The team was committed to building standard product homes with a Home Energy Rating System (HERS) Index between 45 and 55 and with ENERGY STAR ${ }^{\circledR}$ Version 3 certification. As part of the commitment to energy performance, Brookfield decided to build a Passive House to be certified through Passive House Institute US. IBACOS partnered with Brookfield to provide design assistance for the Passive House initiative.

The U.S. Department of Energy (DOE) Building America research team IBACOS undertook the Passive House project for several reasons:

- To explore various strategies to achieve very low and zero energy housing and to determine if a production builder could incorporate any of those strategies into its standard production practice

- To understand if a builder can practically meet Certified Passive House standards in a production design and construction environment

- To work with the first production builder to design and construct a Certified Passive House in the United States.

Brookfield was very interested in distinguishing itself as the first production builder to design and construct a Certified Passive House in the United States and to build the first Passive House in Colorado. Brookfield also was interested in seeing if this could be a viable option for homebuyers to select as an upgrade to a standard design.

IBACOS evaluated the builder's Passive House and two of its new standard design houses in the same community to compare systems and performance characteristics.

As a companion effort, IBACOS also helped Brookfield conceptualize products for Denver's Brighton Heights area, where the builder was considering building to DOE Zero Energy Ready Home (ZERH) standards. IBACOS provided strategies that Brookfield can use if it chooses to pursue a ZERH plan for that market.

\footnotetext{
${ }^{3}$ Passive House Institute US, www.phius.org/home-page.
} 


\subsection{Research Questions}

This project was initiated with the intention of answering the following research questions:

1. How does the annual space-heating and space-cooling system runtime in the Passive House compare to a house that has Brookfield's standard energy-efficiency package?

2. How do the room-to-room and room-to-thermostat temperature offsets in the Passive House compare to a house that has Brookfield's standard energy-efficiency package?

3. Was the installed space-conditioning system appropriate to use in a cold-climate Passive House that will maintain occupant comfort to Air Conditioning Contractors of America (ACCA) Manual RS (Rutkowski 1997) and American Society of Heating, Refrigerating and Air-Conditioning Engineers, Inc. (ASHRAE) Standard 55-2010 (ASHRAE 2010) guidelines?

4. How does the actual space-heating and space-cooling energy use compare to Building Energy Optimization (BEopt ${ }^{\mathrm{TM}}$ ) Version 2.1.0.1 (NREL 2013) or other energy simulations when actual weather conditions are normalized?

5. What are the costs associated with production construction methods to achieve ZERH levels of energy performance?

6. How does the adoption of ZERH impact a builder's business planning? 


\section{Overview of the Builder}

Brookfield in Denver, Colorado, was created in 2012 as a part of Brookfield Residential Properties, Inc., a land development company owned by Brookfield Asset Management. Brookfield's intent is to be known in the Denver Metro market as a "high-design production homebuilder." The Brookfield management team worked together previously at another production homebuilding company; therefore, the startup of this division was based on a common understanding of the homebuilding process and the capabilities of each team member. One goal for the company is to keep the combination of home performance, technology, and energy efficiency as a key value proposition for its customers - in the home, throughout the home-buying process, and throughout the entire customer experience. This builder sees its product offering as always being one or two steps ahead of code-minimum construction. The company seeks to be nimble, with a process for investigating and adopting new products and process innovations that can improve the performance of its homes.

As of early 2014, the target price range for this builder's homes at the Midtown community is approximately $\$ 310,000$ to $\$ 370,000$. As the builder moves into other communities, product in the range of $\$ 180,000$ to $\$ 250,000$ also will be offered. All are detached single-family homes of 1,800 to $2,200 \mathrm{ft}^{2}$. Given the dramatic decrease in housing starts and buyers in Denver since 2009 , the builder is seeking to appeal to all buyer classes by providing home designs that will work for anyone. The homes employ key universal design features to make them easily adaptable over time. In 2013, this builder planned to have 47 home sales in three communities with four product lines, growing to approximately 320 sales in 2015 with 10 product lines, with houses not larger than 2,700 $\mathrm{ft}^{2}$. Figure 1 shows the location of the Midtown community in Denver and the locations of the Passive House and two of the builder's standard construction control homes discussed in this report.
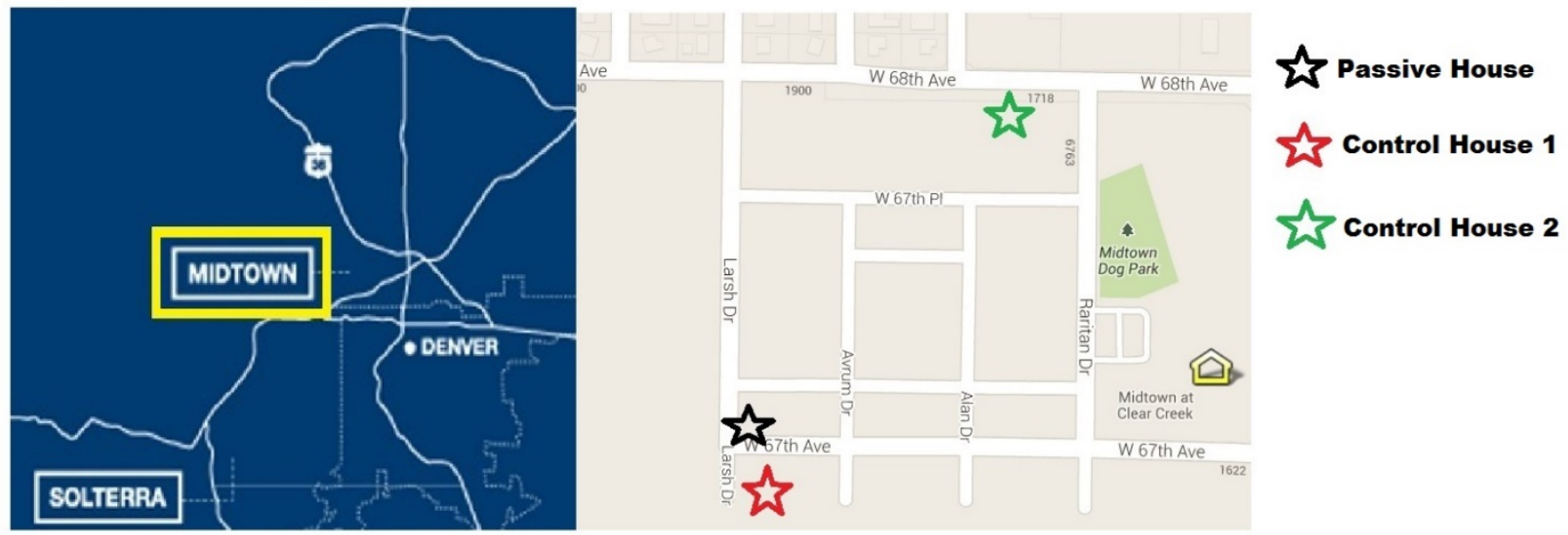

Figure 1. Location map (left) and site plan (right) of Brookfield's Midtown community in Denver. The stars indicate the three houses monitored in this project.

\subsection{Builder Standard Construction Practices}

The builder currently uses a poured concrete foundation wall with R-19 perforated vinyl-covered fiberglass batt insulation below grade (R-21 blown-in cellulose if a finished basement). The $2 \times 6$ 
wall cavity is filled with 2 in. of closed-cell spray polyurethane foam (ccSPF) insulation plus $3-1 / 2$ in. of cellulose. The rim joist has 2 in. of ccSPF insulation plus R-13 fiberglass batt insulation. The attic insulation is R-50 blown cellulose. The ducts typically are installed in the basement; chases made of uninsulated sheet metal go to the upper floors. The heating, ventilating, and air-conditioning (HVAC) system consists of a 13 seasonal energy efficiency ratio air conditioner that is optional to the homeowner but as of April 2015 has been installed in every home in Midtown, a 93 annual fuel utilization efficiency (AFUE) Lennox natural gas furnace, and a tankless gas water heater.

The builder plans to have its standard production homes, represented by the two control homes, achieve a HERS Index of 45 to 55 and to be ENERGY STAR ${ }^{\circledR}$ Version 3 certified, which is notably higher performance than many production homebuilders in the area currently offer.

Table 1 provides some details about the builder's standard production home package used in the two control homes compared to those of the Passive House package. See Appendix A for more comprehensive specification comparisons. 
Table 1. Specification Packages for the Builder's Standard Product and the Passive House

\begin{tabular}{|c|c|c|}
\hline Specifications & $\begin{array}{c}\text { Builder Standard } \\
\text { Package (Control Houses) }\end{array}$ & $\begin{array}{l}\text { Passive House } \\
\text { Package }\end{array}$ \\
\hline Slab R-Value & 0 & $\begin{array}{l}4 \text { in. of extruded polystyrene foam } \\
\text { (R-20) under-slab/slab edge }\end{array}$ \\
\hline Wall Cavity R-Value & R-27, GI & $\mathrm{R}-11+\mathrm{R}-30 \mathrm{GI}$ \\
\hline Ceiling/Attic R-Value & $\mathrm{R}-50$ & $\mathrm{R}-60$ \\
\hline Heating & $\begin{array}{l}\text { Natural gas furnace } \\
96 \text { AFUE Lennox }\end{array}$ & $\begin{array}{c}\text { First Company fan coil unit with hot } \\
\text { water coil with heat supplied from the } \\
\text { Navien Condensing Combi unit } \\
\sim 0.93 \text { AFUE }\end{array}$ \\
\hline Air Conditioning & $\begin{array}{c}13 \text { seasonal energy efficiency ratio } \\
\text { ducted split system }\end{array}$ & $\begin{array}{l}21 \text { seasonal energy efficiency ratio } \\
\text { ducted split system }\end{array}$ \\
\hline Ventilation & $\begin{array}{c}\text { Exhaust only at laundry room } \\
\text { ( } 3 \text { bedrooms at } 3,200 \mathrm{ft}^{2}=62 \mathrm{CFM} \text { ) }\end{array}$ & $\begin{array}{c}\text { Zehnder ComfoAir } 350 \text { ERV, } \\
91 \% \text { efficient }\end{array}$ \\
\hline $\begin{array}{l}\text { Window U-Value/ } \\
\text { Solar Heat Gain Coefficient }\end{array}$ & $0.3 / 0.3$ & $0.14 / 0.5$ \\
\hline Door U-Value & $>0.167$ & 0.30 (glazed); 0.14 (solid) \\
\hline Air Sealing & N/A & $0.6 \mathrm{ACH} 50$ tested \\
\hline Shading & N/A & Recessed windows \\
\hline Lighting & $\begin{array}{c}100 \% \text { compact fluorescent lamps } \\
\text { interior, } \\
\text { exterior, and garage }\end{array}$ & $\begin{array}{l}100 \% \text { compact fluorescent lamps and } \\
\text { light-emitting diodes interior, exterior, } \\
\text { and garage }\end{array}$ \\
\hline
\end{tabular}

ACH50 is air changes per hour at 50 pascals. ERV is energy recovery ventilator. GI is Residential Energy Services Network insulation installation Grade I. N/A is not applicable. 


\section{Test and Control Houses}

The test house (built as a Passive House) and the two control houses (built to the builder's standards) were constructed in the Midtown area of Denver, Colorado. The Passive House was built first, sold, and occupied. The other two houses followed.

\subsection{Passive House}

The Passive House is a new floor plan designed by KGA|studio architects from Denver, Colorado. The home is two stories with approximately $2,421 \mathrm{ft}^{2}$. It includes three bedrooms and two and a half bathrooms. The front of the home faces south, and the exterior is clad in stucco and siding, consistent with the builder's standard construction methods. Figure 2 and Figure 3 show the first- and second-floor plans, respectively. Figure 4 shows a view of the front and side elevations. See Appendix B for the full drawing set of the Passive House.

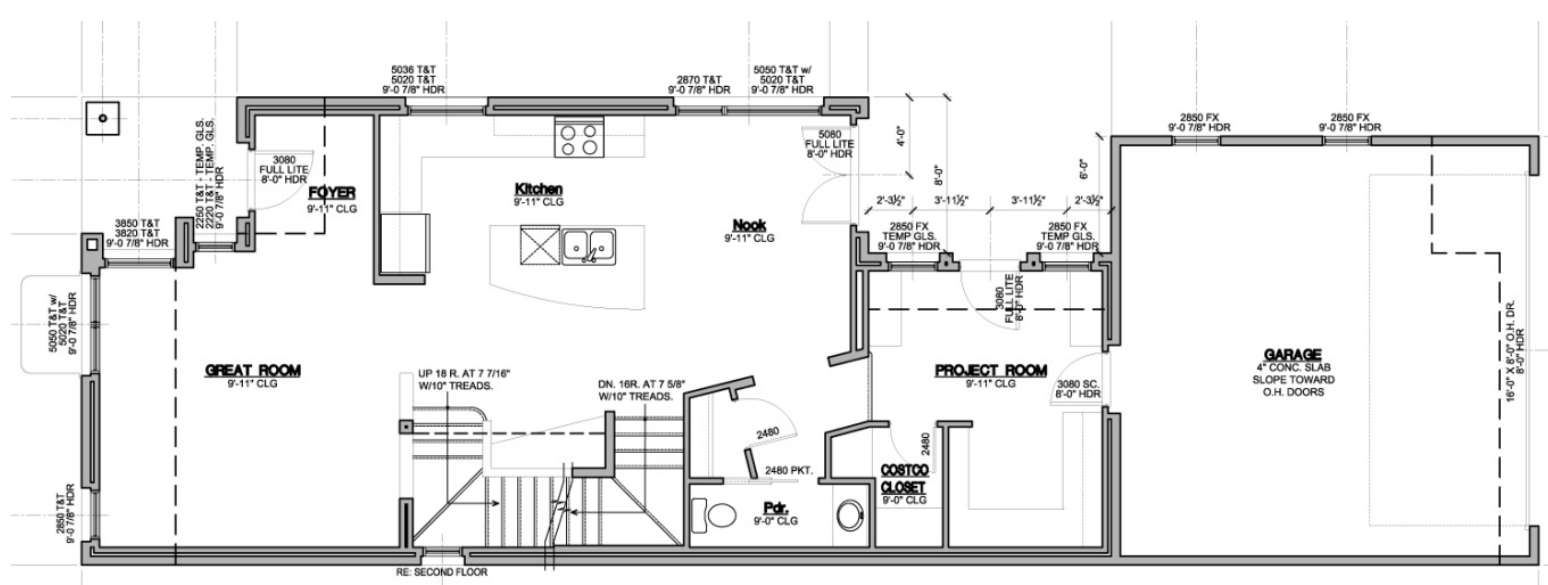

Figure 2. First-floor plan of the Passive House. Image from KGA|studio architects

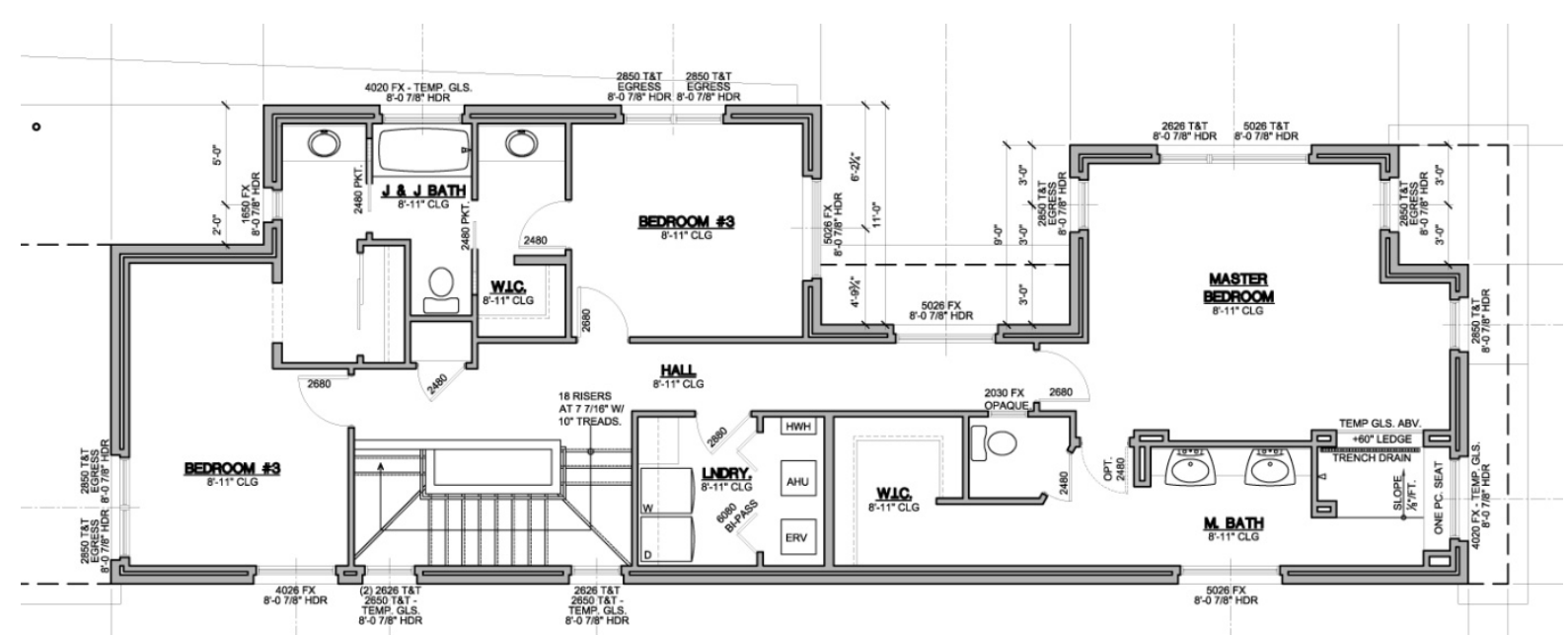

Figure 3. Second-floor plan of the Passive House. Image from KGA|studio architects 


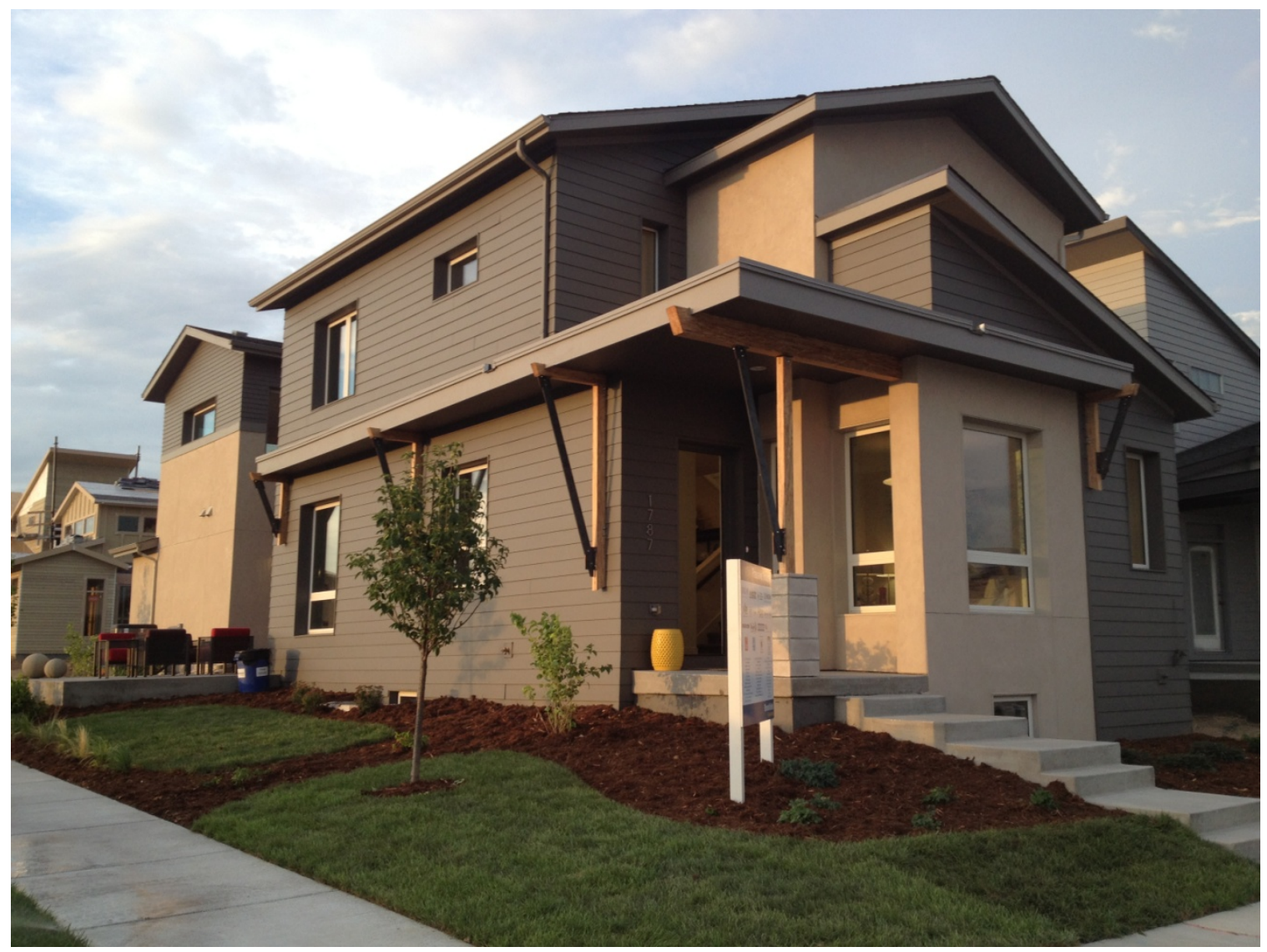

Figure 4. Front and side elevations of the Passive House

\subsection{Control House 1}

Control House 1 is located directly across the street from the Passive House. This control house had a different layout than that of the Passive House, as shown in Figure 5 through Figure 7.

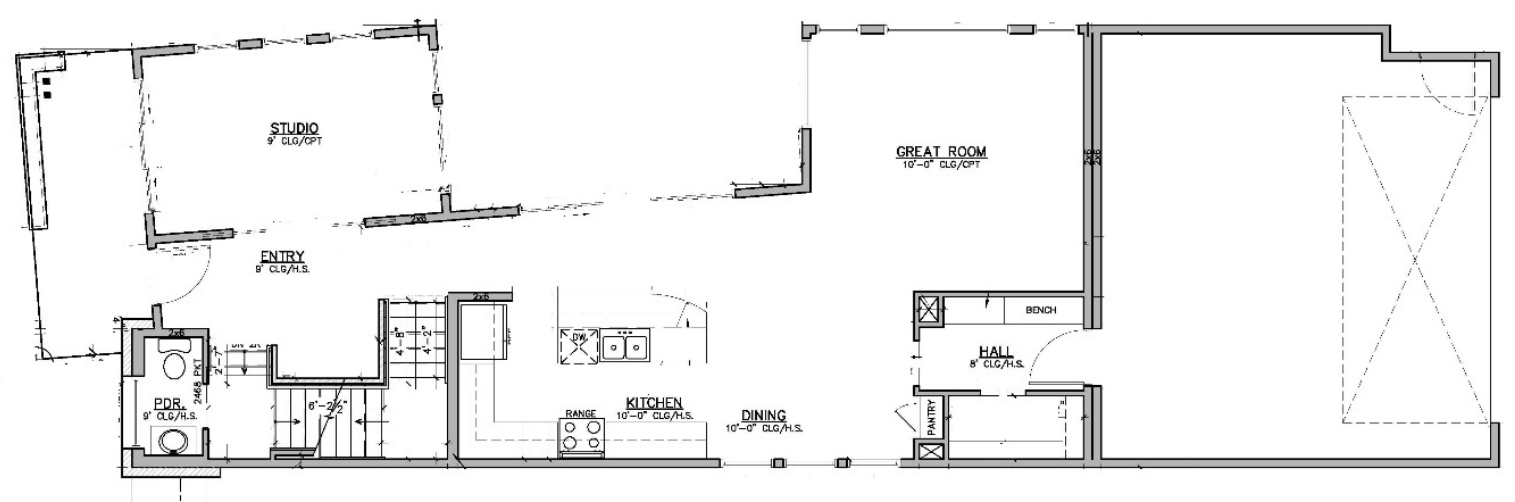

Figure 5. First-floor plan of Control House 1. Image from Brookfield Homes Denver 


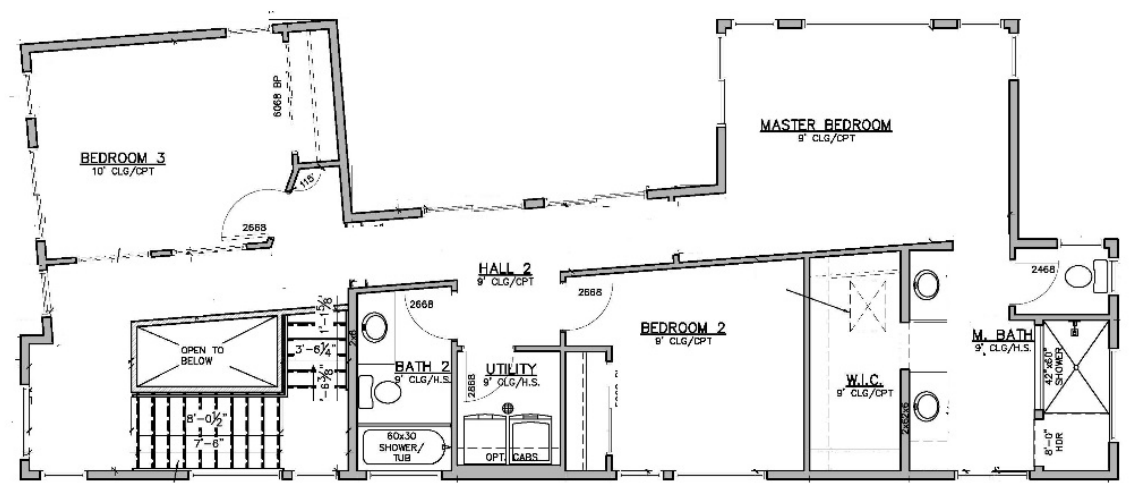

Figure 6. Second-floor plan of Control House 1. Image from Brookfield Homes Denver

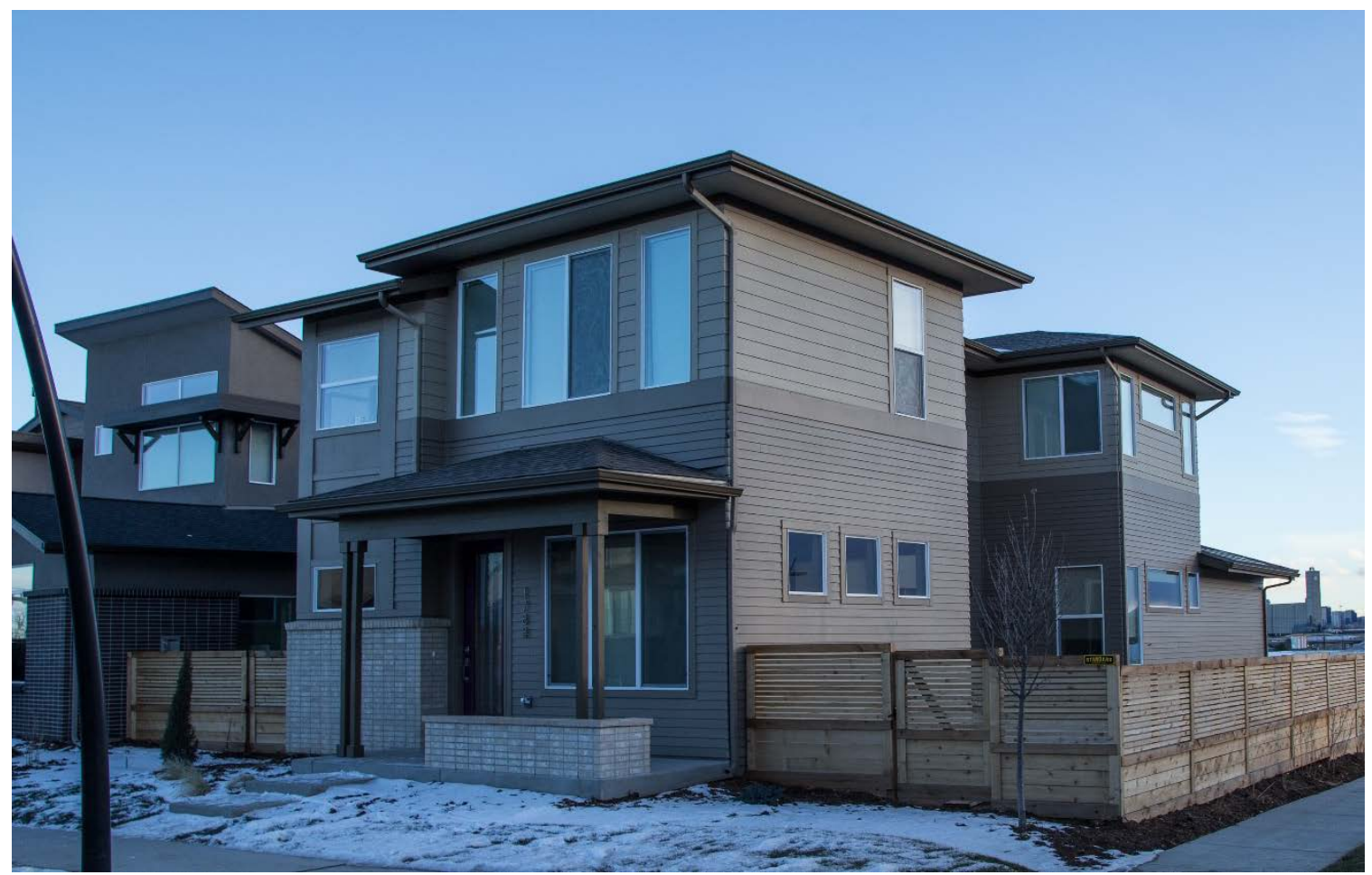

Figure 7. Front and side elevations of Control House 1

\subsection{Control House 2}

Control House 2 is located in the same Midtown community as the Passive House and Control House 1 but is a few streets away. The floor plan of Control House 2 also differs slightly from those of the Passive House and Control House 1. Figure 8 through Figure 10 show the floor plan and elevations of Control House 2. 


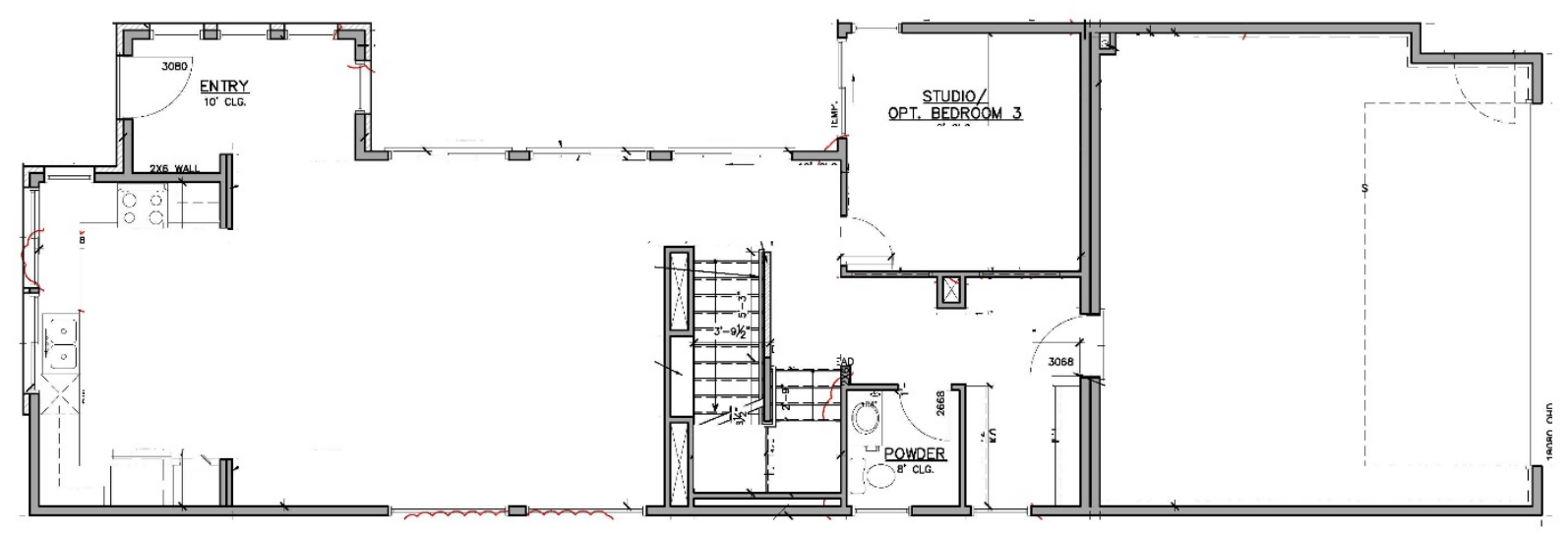

Figure 8. First-floor plan of Control House 2. Image from Brookfield Homes Denver

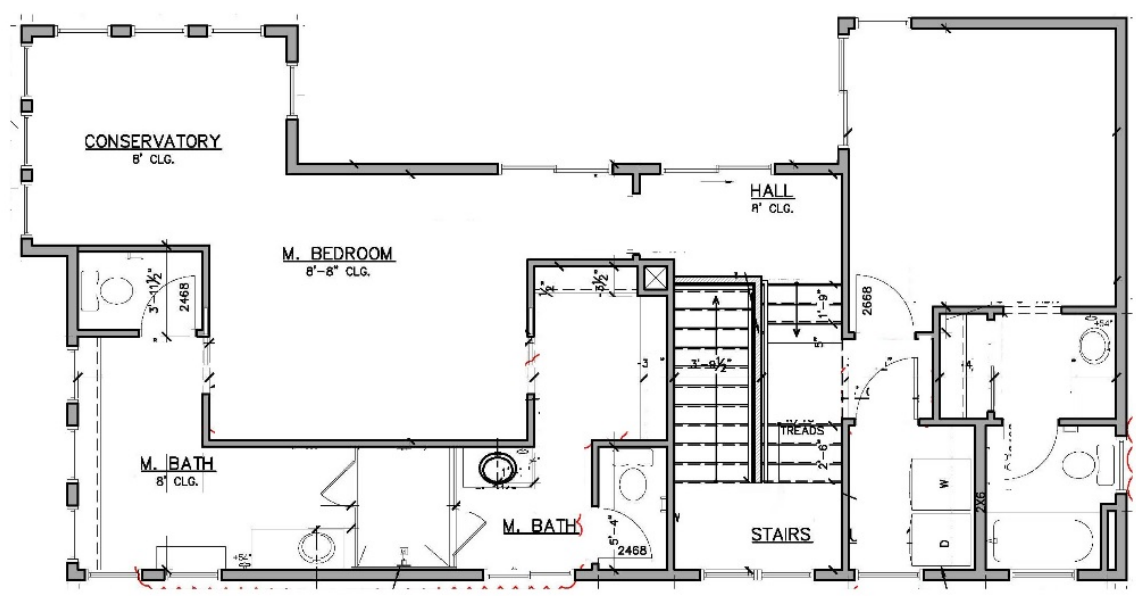

Figure 9. Second-floor plan of Control House 2. Image from Brookfield Homes Denver 


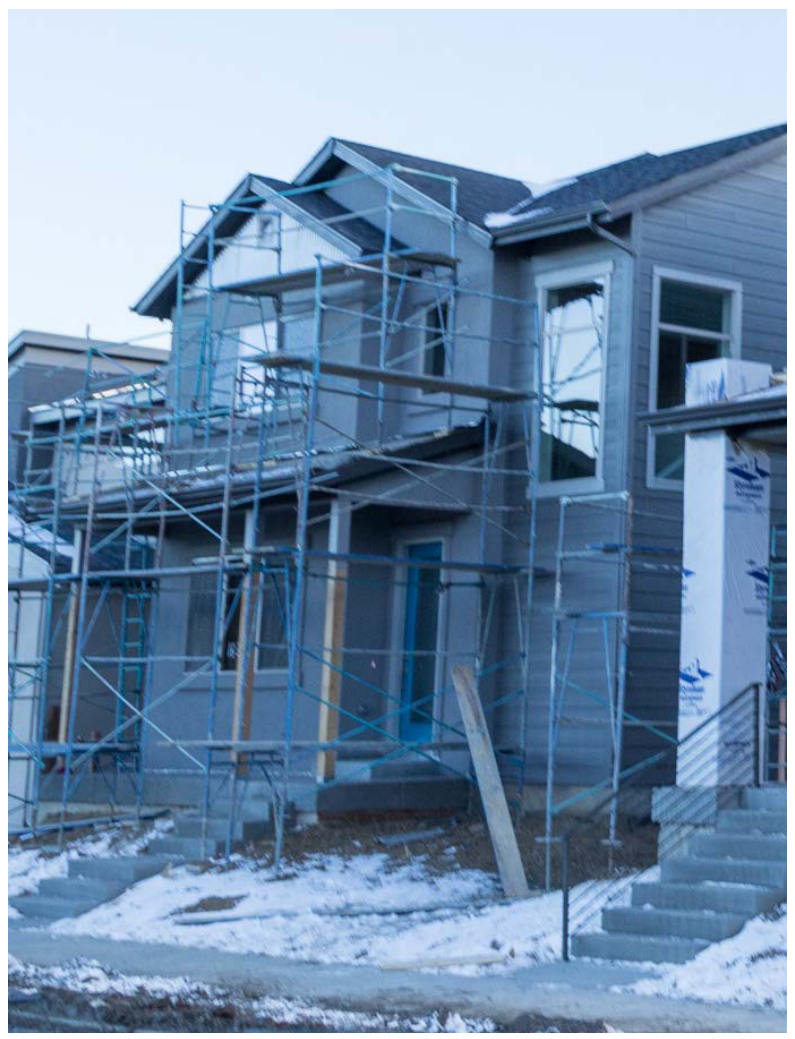

Figure 10. Front elevation of Control House 2

\subsection{Passive House Design Process}

This was a pilot Passive House initiative for several of the involved stakeholders. Because of the industry interest in Passive Houses, this report provides documentation of the Passive House design process.

The project team instituted an iterative integrated design process ${ }^{4}$ in early 2013. Passive House Planning Package (PHPP) modeling (Passive House 2012) was undertaken as the architect created schematic designs. WUFI Passive ${ }^{5}$ was investigated as a modeling tool, but the team decided to use the more familiar PHPP tool, given the constraints of the project timeline. The mechanical and framing contractors were integrated into the design process so various framing strategies would ensure that all ducts would be inside conditioned space. Feedback was provided to the design team about options and strategies to bring the house into Passive House compliance, such as different window sizes, orientations, and frame-to-glass ratio options; different ventilation system options; and different combinations of insulation in the various assemblies. The home maintained its intended look and feel from the outside looking in as the home design evolved. Figure 11 and Figure 12 illustrate the subtle evolution of the floor plans through the design process.

\footnotetext{
${ }^{4}$ See Chapter 3, Volume 12, Building America Best Practices Series, http://apps1.eere.energy.gov/buildings/publications/pdfs/building_america/cold_climate guide 40percent.pdf.

${ }^{5}$ WUFI Passive software, https://wufi.de/en/software/wufi-passive/.
} 

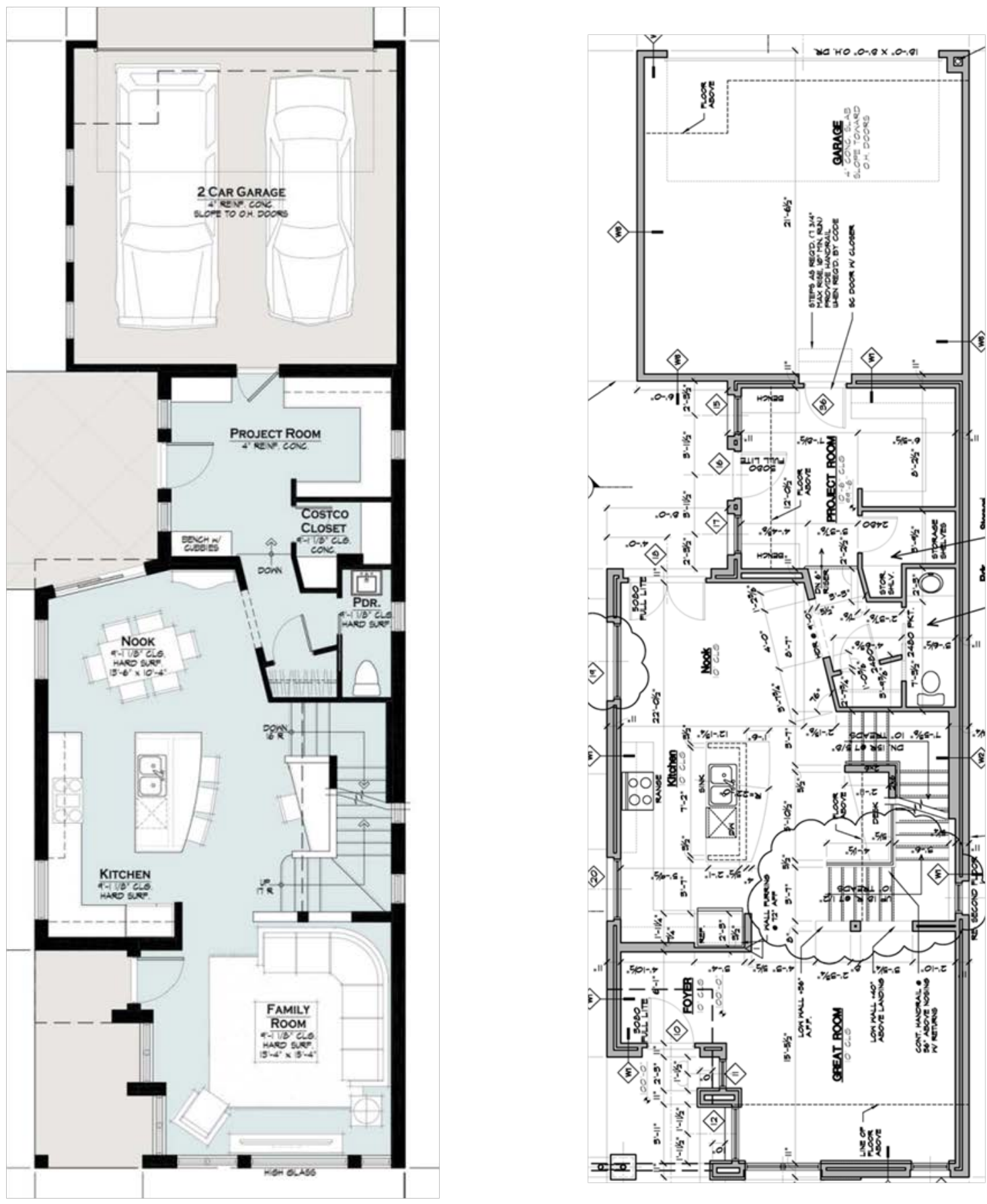

Figure 11. First-floor plan comparison-early schematic (left) to final (right). Image from KGA|studio architects 

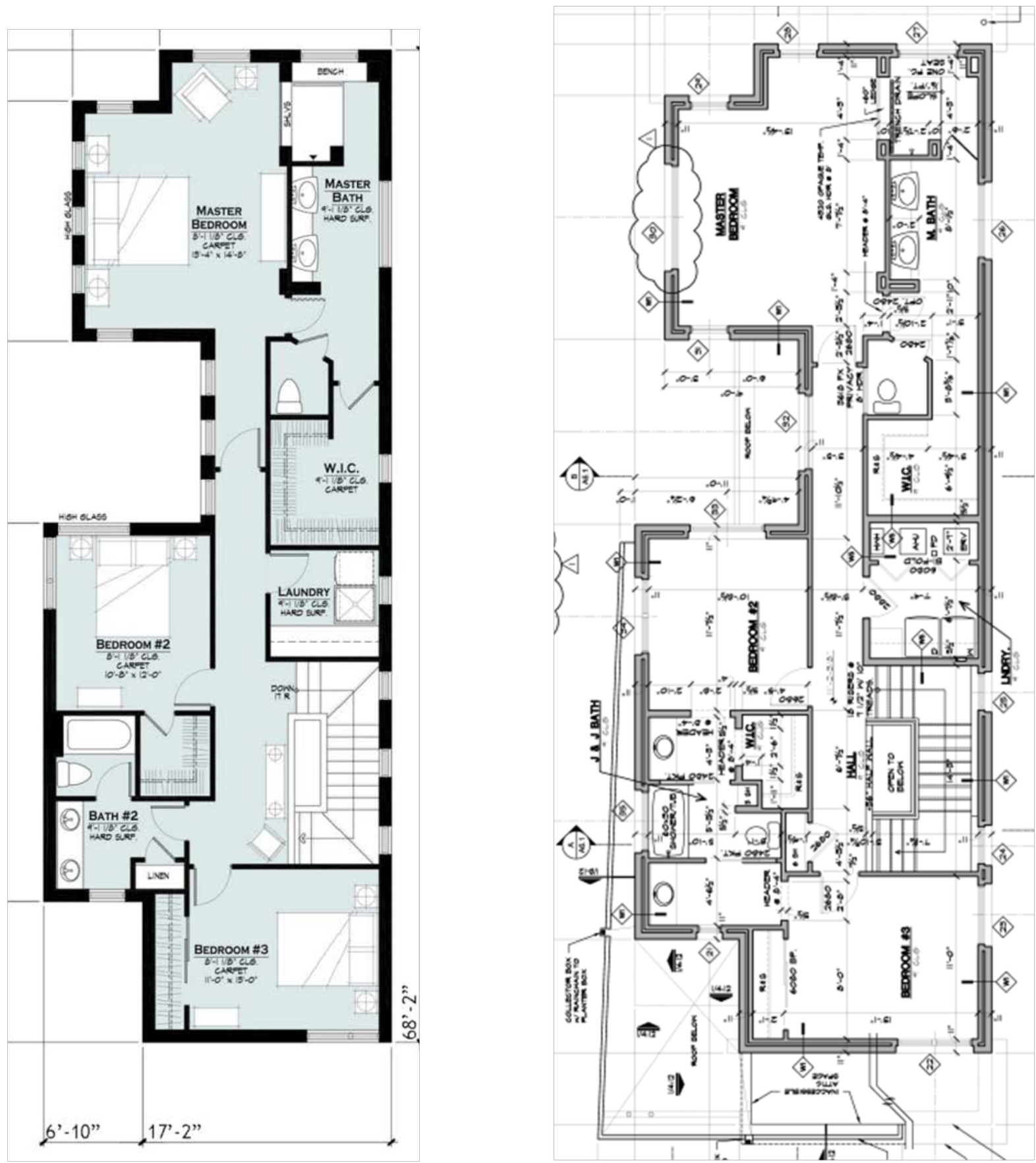

Figure 12. Second-floor plan comparison-early schematic (left) to final (right). Image from KGA|studio architects

Integrating mechanical and framing trade partners into the design process early had an impact on space planning and design. A significant challenge was met in developing structural details for the high wind loads in the Denver region. The double-stud wall assembly and the lack of any 
significant interior partitions on the first floor meant significant structural details were needed to meet shear bracing requirements and still achieve a continuous thermal enclosure with minimal thermal bridges. Figure 13 shows the first and second floors of the Passive House design; shear walls are noted with dotted lines.
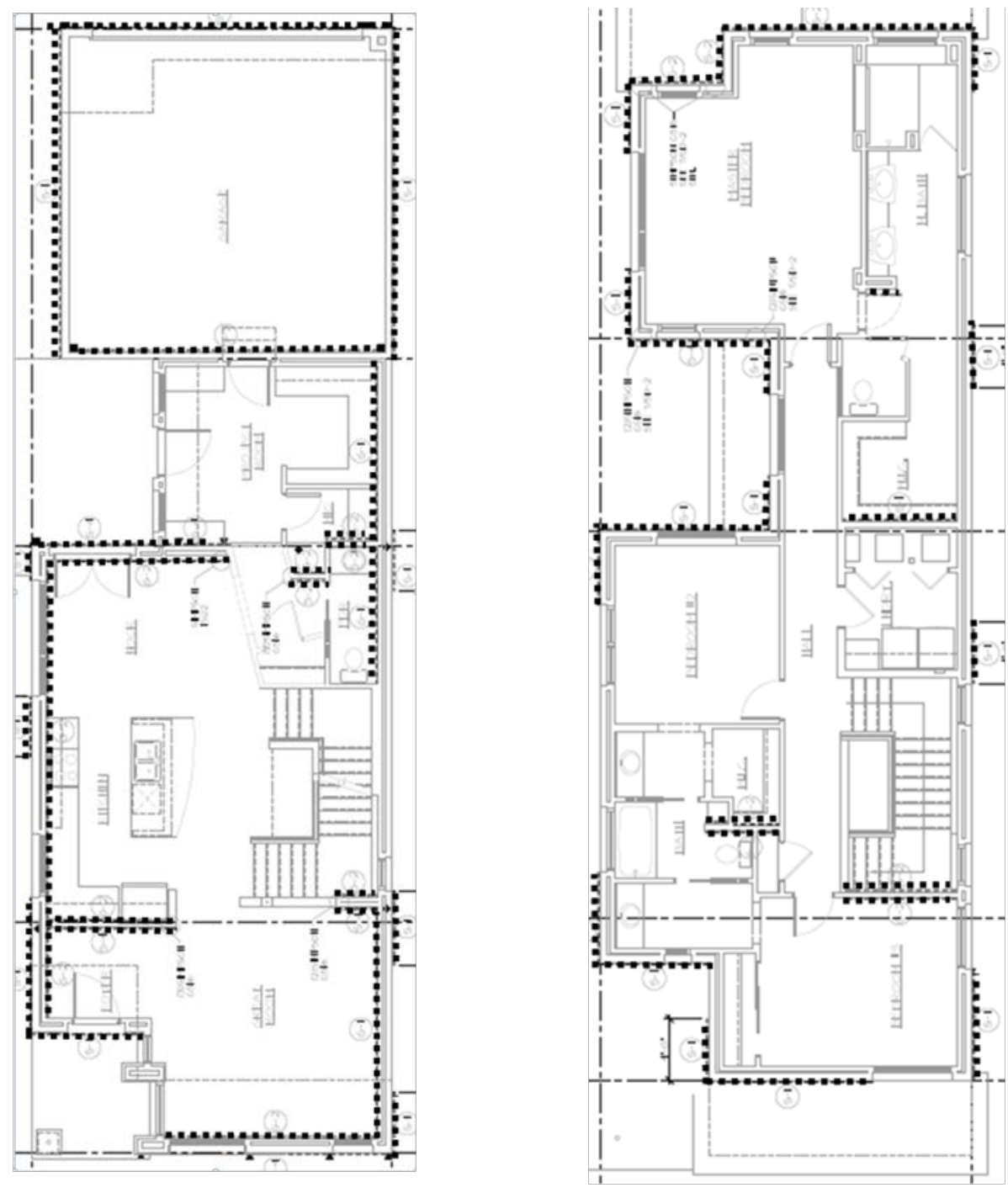

Figure 13. First-floor (left) and second-floor (right) plans showing shear bracing. Image from Green City Consultants Structural Engineers

Two primary differences between a Passive House certification and many other above-code energy-efficiency programs are the stringency of the pass-fail criteria and the site-specific nature of the design and modeling. Production builders generally use a worst-case approach for house design; however, for certain designs, meeting the Passive House targets is easier if careful passive solar design is undertaken. The PHPP spreadsheet is quite cumbersome for undertaking worst-case analysis, because each component must be entered with its specific characteristics. WUFI Passive is much more flexible in this respect, because it allows the designer to easily 
rotate the model by orientation or to create duplicate cases to modify certain design features (e.g., window area or shading).

\subsection{Passive House Design Strategies}

Given that the basic premise of a Passive House is to provide a very low-energy enclosure, the team began with some key characteristics in the schematic design phase that would influence the design. These included 12-in.-thick walls, passive solar design strategies, a mechanical closet located inside conditioned space, and more than 20-in. full insulation depth in the attic. As the PHPP modeling proceeded, several key design principles became apparent that significantly influenced space layout and aesthetics.

\subsubsection{Thermal Enclosure}

Several key differences in the design and energy modeling of the Passive House relative to the thermal enclosure are of note for others who are considering achieving Passive House certification. These differences had an impact on the design and system integration for this project.

\subsubsection{Basement Insulation}

To achieve the Passive House energy use criteria, significantly more basement insulation was used, and thermal bridges were minimized. The highly insulated basement, combined with a code-minimum number of windows, led to low basement heating and cooling loads compared to those of the first and second floors.

\subsubsection{Window Selection}

Two factors were considered in detail for the Passive House window selection: (1) frame versus glass area and the impact on solar gain, and (2) the shading of each individual window. Figure 14 and Figure 15 show iterations of the floor plan from an early schematic design to the final.
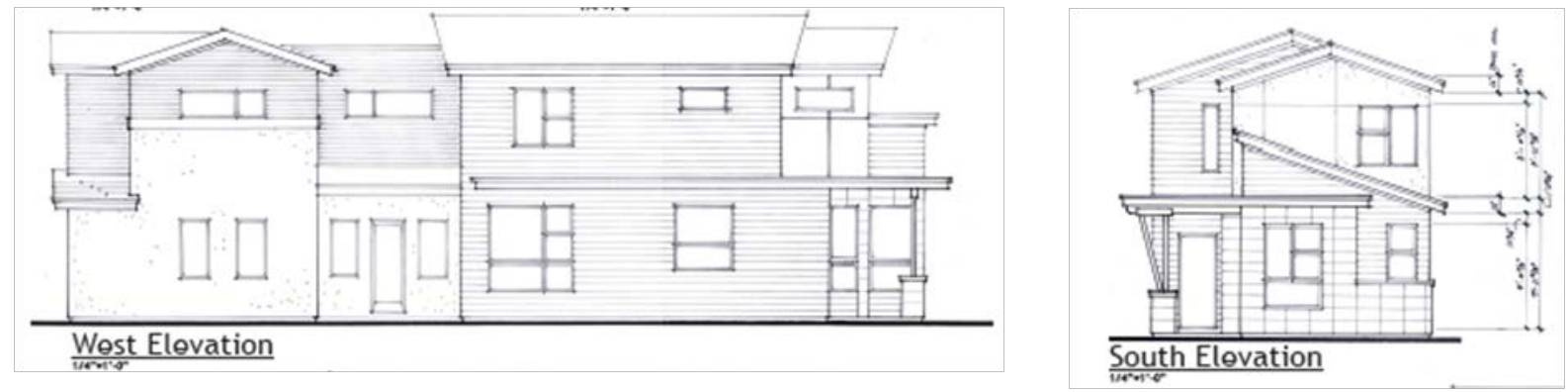

Figure 14. Schematic design elevations show the window layout. Image from KGA|studio architects 

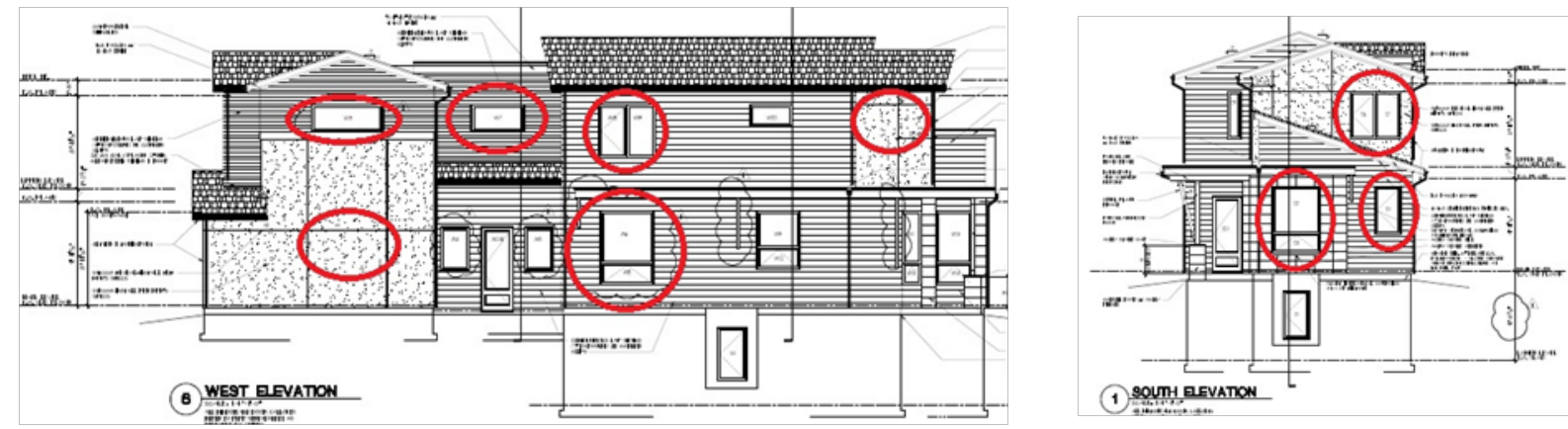

Figure 15. Final design elevations show the window layout. Note the differences in window sizes and the number of individual windows. Image from KGA|studio architects

The initial design of this house included a large number of small individual windows, or groups of small and large windows, to complement the aesthetics of the nearby homes. After an initial PHPP model was completed, it was apparent that the significant number of windows and relatively high frame area to window area would burden the energy performance (i.e., more conduction through frames and less solar gain) and would increase the cost of the overall window package. Figure 16 shows the Passive House in the context of the other houses on the same block in the Midtown community. The Passive House has a larger uninterrupted glazing area that maximizes solar gain and lowers overall heat transfer.

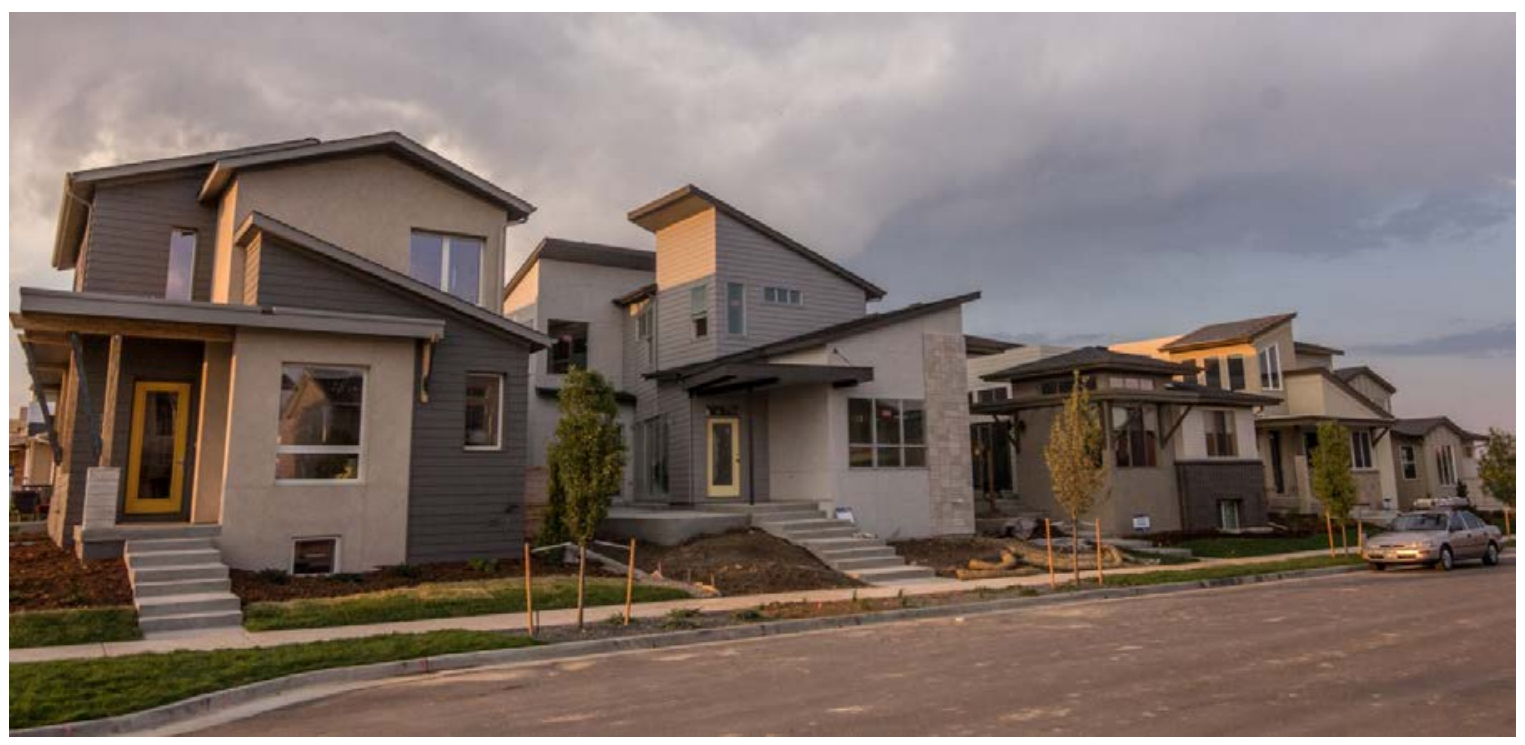

Figure 16. Test house (Passive House) (far left) and other production houses in Midtown

\subsubsection{Final Thermal Enclosure}

Appendix A tabulates the detailed final thermal characteristics that resulted from the Passive House design process and provides a comparison to the builder's standard practice. 


\subsubsection{Mechanical System Design}

The builder's standard practice is to locate the mechanical system within conditioned space. Typically, the mechanical equipment is located in the basement, and the ducts are routed under the first-floor framing and through the second-floor open-web floor trusses. The basement typically is not finished; therefore, locating the mechanical equipment in the basement is viewed as "free space" compared to above-grade floor area. Basement loads typically are much lower than those of the first or second floor. However, in the Passive House, the very low calculated peak heating and cooling loads and the need for heat recovery on the ventilation system required the team to rethink the approach to the mechanical system location and strategy.

\subsubsection{Comfort System Location}

The Passive House heating and cooling system was located in a mechanical closet on the second floor between the laundry room and the master bedroom walk-in closet. This space was centrally located on an outside wall to facilitate short duct runs between the ERV and the outside and provided some sound isolation from the main living spaces in the house. This location also enabled the shortest duct runs to the first and second floors where the highest airflows were needed, with only one short duct run to the basement. This is in contrast to a typical system that would have a large central trunk for supply air from the basement to the second-floor system. A down-flow fan coil using hot water from a nonpotable loop off the water heater was used for heating. The smallest conventional high-efficiency direct-expansion outdoor condensing unit was selected for air conditioning with a companion indoor evaporator coil.

\subsubsection{Ventilation Equipment Location}

Passive House analysis takes into account the energy transfer through the walls of the ducts serving intake and exhaust to and from the ERV unit. This is generally ignored in most energy modeling software. Passive House modeling requires that the specific lengths and R-values of intake and exhaust ducts be entered.

\subsubsection{Considerations to Integrate Ventilation and Space-Conditioning Systems}

One widely discussed aspect of Passive House construction is that the thermal enclosure performs well enough that the space conditioning could almost be achieved with the ventilation system. For a production builder, that strategy would entail a high level of risk for two reasons:

- Customers are unaccustomed to "not having a heating and cooling system," so the sales staff must be well equipped to overcome this concern and objection.

- Production builders are quite attuned to occupant comfort, and in IBACOS' experience, comfort complaints are not uncommon, even in high-performance homes.

The team thus decided to install a small, dedicated heating and cooling system in the Passive House, as shown in Figure 17. Its nominal heating capacity is $19,000 \mathrm{Btu} / \mathrm{h}$; the nominal cooling capacity is $24,600 \mathrm{Btu} / \mathrm{h}$. 

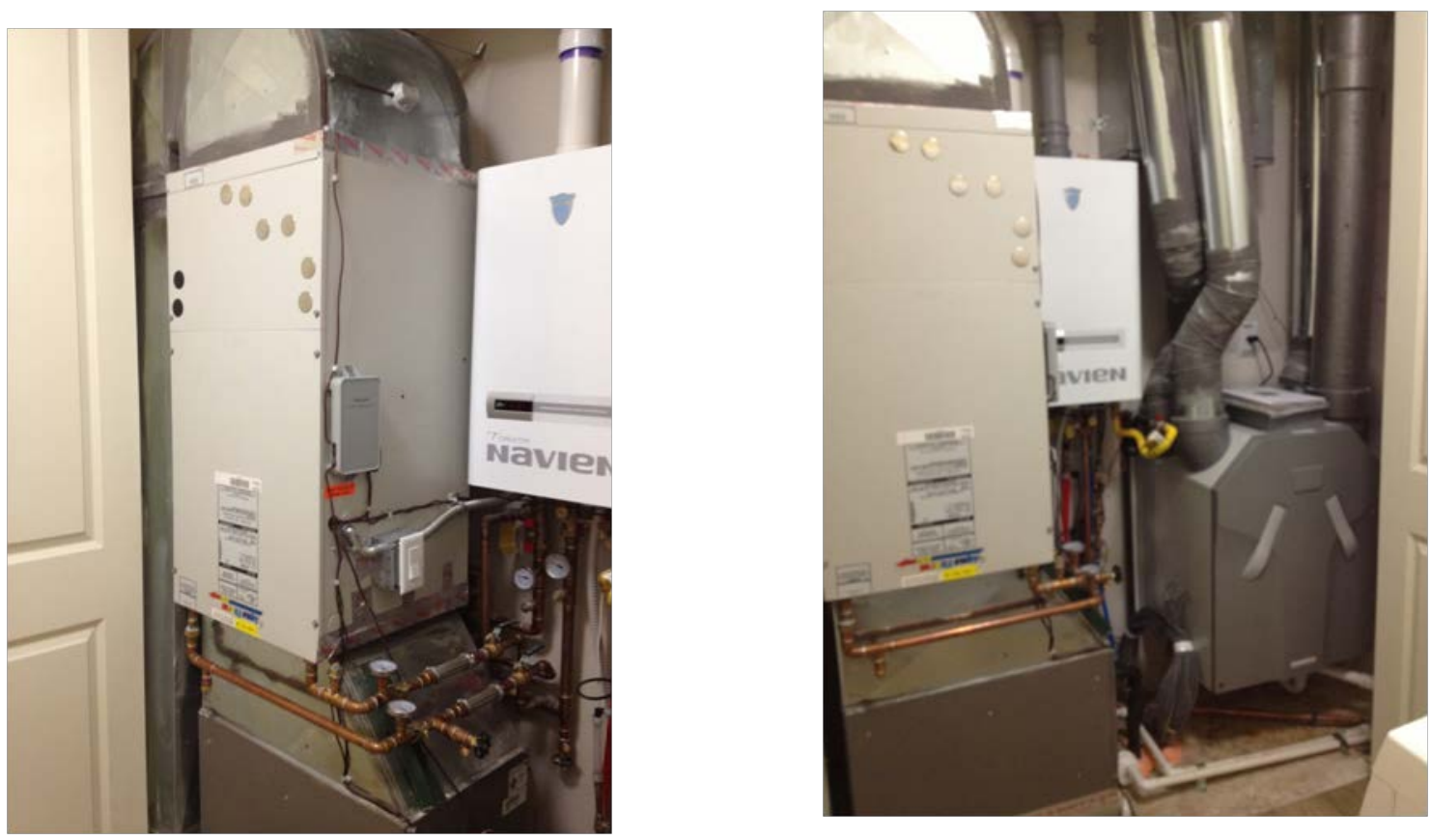

Figure 17. Mechanical closet with the air handling unit and water heater (left) and the ERV (right)

\subsection{Zero Energy Ready Home Program Compliance}

Aside from its interest in Passive Houses, Brookfield has an interest in building homes to meet the DOE ZERH standards in the Brighton Heights location. As a companion effort to the Passive House objectives of this project, IBACOS helped Brookfield evaluate its opportunities and challenges in meeting the ZERH program requirements.

The DOE ZERH program developed out of the earlier DOE Challenge Home program. DOE describes a ZERH as a "high performance home which is so energy efficient, that a renewable energy system can offset all or most of its annual energy consumption." ${ }^{\prime 6}$ Although committed to and experienced with high-performance housing, this builder encountered a technical challenge while evaluating its ability to meet all DOE ZERH program requirements at this time in Brighton Heights. The ZERH program includes mandatory requirements to achieve minimum performance levels or specifications in the following building areas: envelope, duct system, water efficiency, lighting and appliances, indoor air quality, and renewable "ready." The program also requires compliance with either a prescriptive specification package or performance that is at least equivalent to the ZERH "Target Home" based on a HERS Index score.

IBACOS and Brookfield evaluated the design and specification changes necessary for one of the builder's floor plans to comply with ZERH requirements (DOE 2014). Although many of the builder's standard specifications already comply with ZERH program requirements, other program requirements presented specific challenges. No ZERH was constructed or instrumented for this project.

\footnotetext{
${ }^{6}$ www.energy.gov/eere/buildings/zero-energy-ready-home.
} 


\section{Mathematical and Modeling Methods}

During the design phase of the Passive House test home, IBACOS used a number of modeling applications and mathematical calculations to optimize the specification package and design details. Key issues addressed were:

- Adhering to Certified Passive House design standards

- Integrating an ERV into the mechanical system

- Optimizing the enclosure and mechanical strategies to meet the builder's objectives

- Identifying potential thermal breaks in the building shell.

IBACOS used the following analytical modeling programs and calculation methods to complete the final design package:

- BEopt Version 2.1.0.1: Optimization of thermal enclosure and mechanical system specifications; energy use and energy savings predictions (NREL 2013)

- $\quad$ THERM: Specification of the amount and location of slab edge insulation (THERM) ${ }^{7}$

- ACCA Manual J and ACCA Manual D used by Four Seasons Heating, Inc. ${ }^{8}$ (the mechanical contractor) to perform the HVAC system load calculations and to design the duct system (Rutkowski 2006 and 2009, respectively)

- $\quad$ REM/Rate software 9 : Energy modeling software to predict the HERS Index of the test house and ZERH package options (Architectural Energy Corporation 2012 and 2014)

\subsection{Cost Optimization}

IBACOS used BEopt software to optimize the thermal enclosure and mechanical system specifications of the test house and to predict the energy consumption and energy savings of the Passive House relative to the standardized reference house as set forth by Building America. BEopt Version 2.1.0.1 was used to analytically model the builder's standard practice (as constructed in Control House 1 and Control House 2), the final Passive House package, and a number of other combinations of energy-efficient construction features. The result of a BEopt analysis is a chart indicating a wide range of energy-saving measures that could be employed; various combinations of measures were charted as individual points. The points show the projected energy savings from a given set of measures (on the horizontal axis) and the expected annualized costs of those measures, including the mortgaged first cost and the annual energy cost (on the vertical axis). The most cost-effective point, and thereby the optimum point, is at the nadir of the curve created at the boundary of these series of points.

IBACOS used BEopt to perform an optimization that considered a large number of possible combinations of energy-efficient construction features. The results are illustrated in Figure 18, which indicates how the builder's standard practice, the Passive House design, and other possible energy-efficiency measures would balance costs and energy savings. The process of optimizing

\footnotetext{
${ }^{7}$ THERM. THERM Finite Element Simulator. Berkeley, CA: Regents of the University of California.

${ }^{8}$ Four Seasons Heating, Denver, CO, www.fourseasonsheatinginc.com/.

${ }^{9} \mathrm{REM} /$ Rate, www.remrate.com.
} 
also considered a number of features that, although required as part of the Passive House package for certification, acted to add cost with little projected energy benefit. Several of those features are called out in the figure.


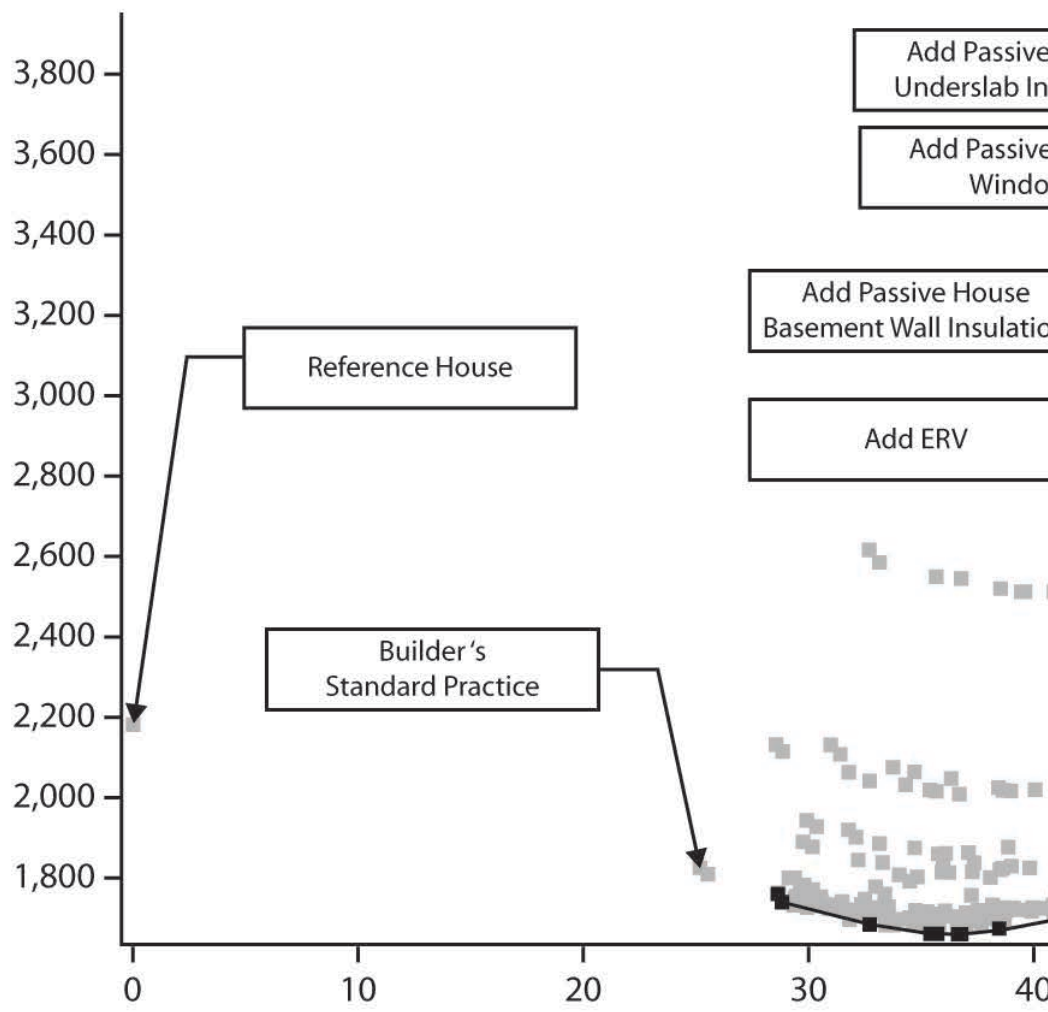

All Passive House Features

Add Passive House Underslab Insulation

Add Passive House Windows Basement Wall Insulation

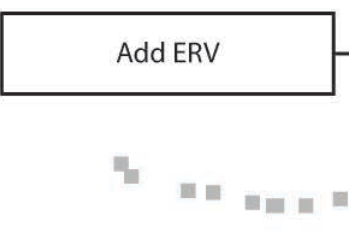
( 
Figure 19 through Figure 21 show the HVAC layout from ACCA Manual D at the basement, first floor, and upper level of the Passive House, respectively. See Appendix C for the full contractor ACCA Manual J and ACCA Manual D calculations.

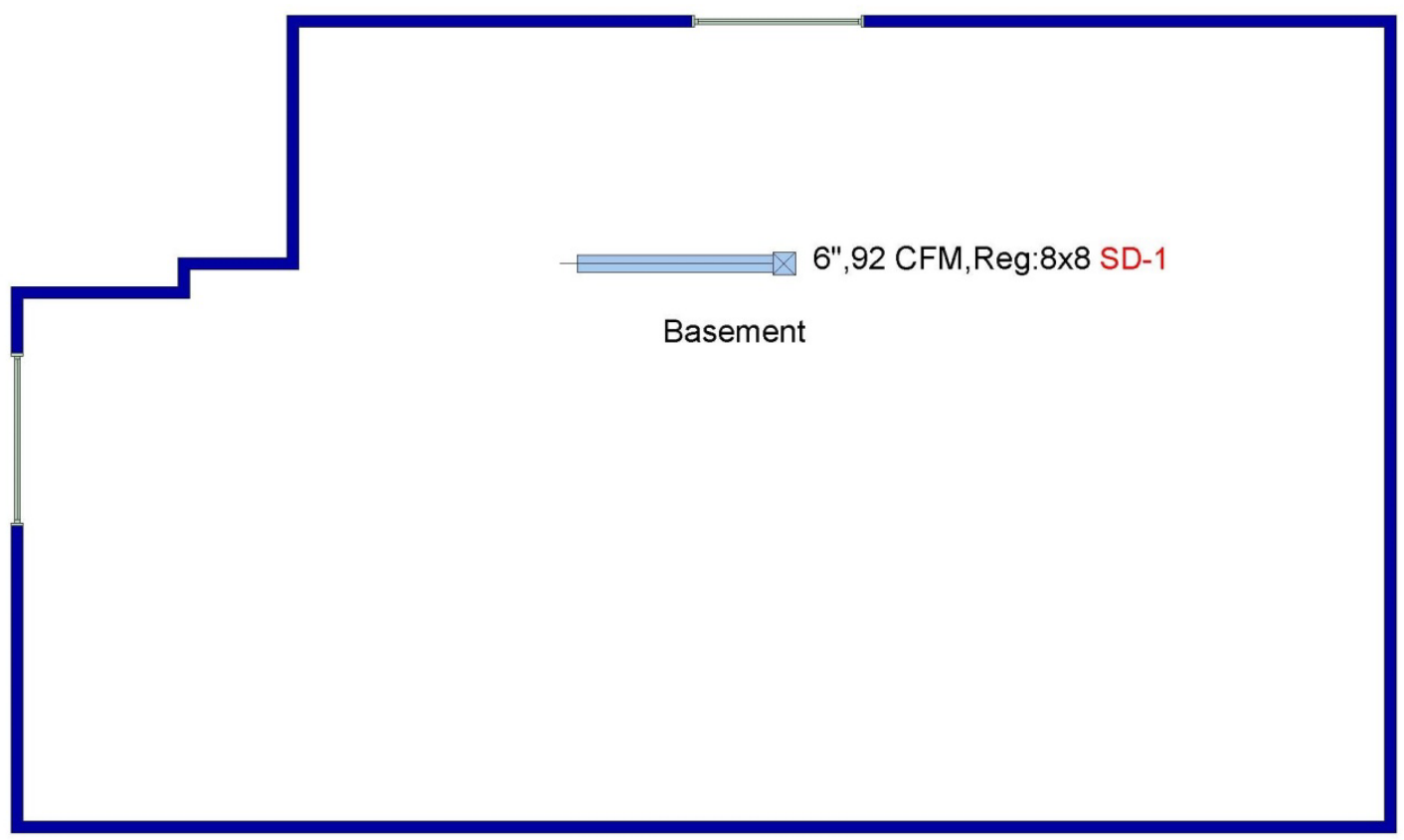

Figure 19. HVAC layout from ACCA Manual D (Rutkowski 2009) at the basement of the Passive House. Image from Brookfield Homes Denver

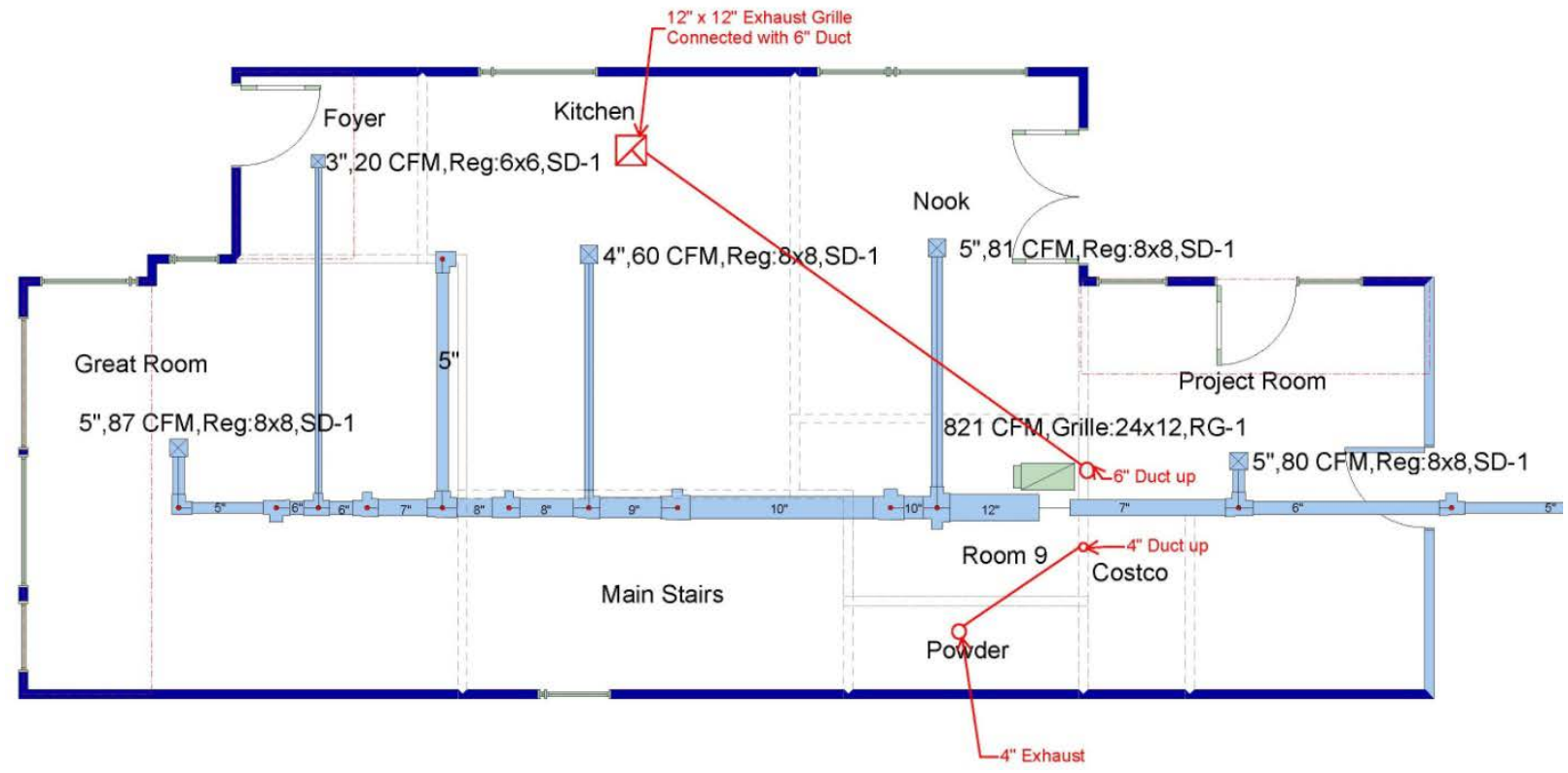

Figure 20. HVAC layout from ACCA Manual D (Rutkowski 2009) at the first floor of the Passive House. Image from Brookfield Homes Denver 


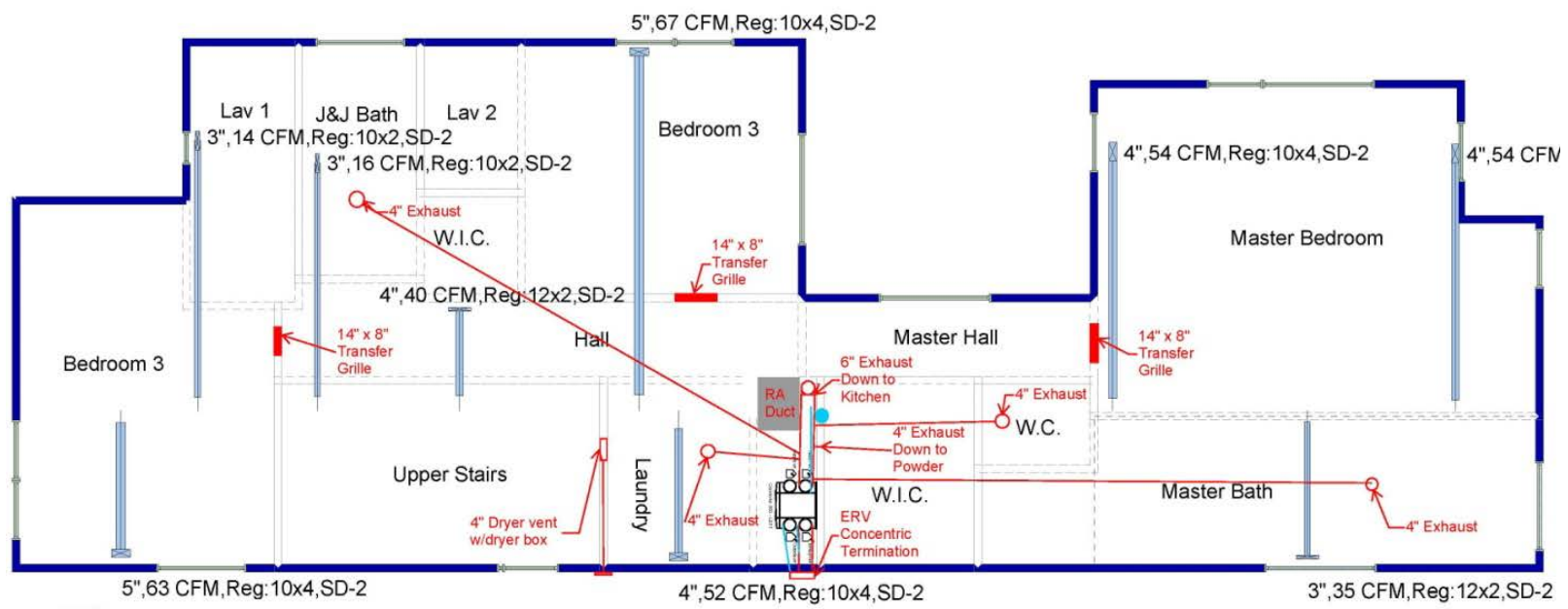

Figure 21. HVAC layout from ACCA Manual D (Rutkowski 2009) at the second floor of the Passive House. Image from Brookfield Homes Denver

\subsection{THERM Modeling}

To be considered a Passive House, the home's construction details had to be analyzed to ensure that any thermal bridging was within the constraints of the certification. Four problematic details were modeled in THERM Version 7.1.19.0 to confirm the heat losses through them were acceptable. This was somewhat challenging, given that the design includes a transition from a full-basement condition to a slab-on-grade condition. As an example, Figure 22 documents the final resolved detail of the slab-to-wall transition.
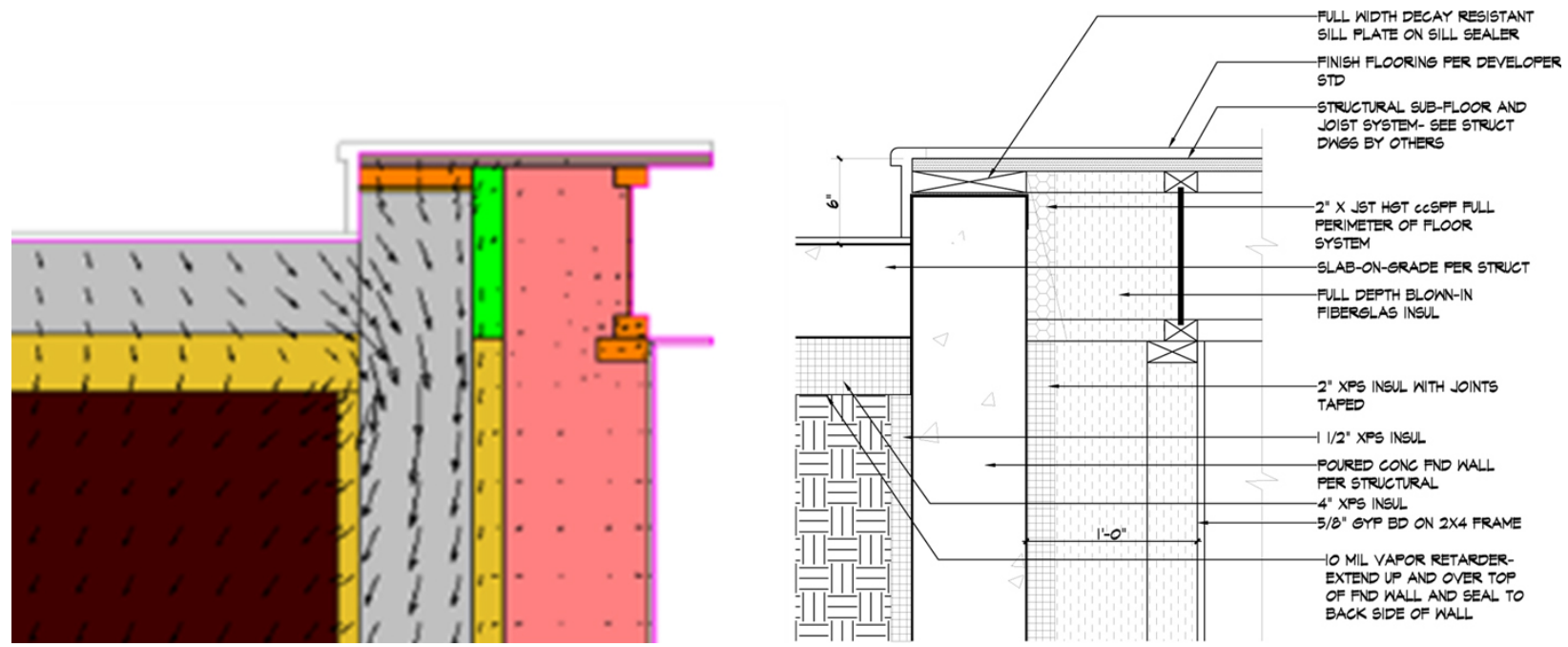

Figure 22. Heat flux and construction of slab-on-grade to foundation wall detail

\subsection{Zero Energy Ready Home Design}

As part of the companion effort, IBACOS investigated the ways for a home in the Brighton Heights area of Denver, Colorado, to reach ZERH standards. Table 2 shows the builder's standard product specifications; the following discussion addresses the simplest recommended upgrades that would need to be made to reach or closely approach ZERH performance levels. 
Table 2. Specifications for the Builder's Standard for the $\mathbf{4 4 2 0}$ Floor Plan in Brighton Heights

\begin{tabular}{|c|c|}
\hline Specifications & Builder's Standard Specification \\
\hline $\begin{array}{l}\text { Basement Foundation } \\
\text { Wall }\end{array}$ & $\begin{array}{l}\text { Basement and crawl space walls insulated with R-19 (GI) } \\
\text { vinyl draped blanket. No insulation under 4-in. concrete } \\
\text { basement floor or on crawl space floor. }\end{array}$ \\
\hline $\begin{array}{l}\text { Above-Grade Exterior } \\
\text { Walls }\end{array}$ & $\begin{array}{l}2 \times 6 \text { wood framing at } 24 \text { in. on center ( } 0.20 \text { framing factor); } \\
\text { R-20 (GI) blown cellulose insulation in cavity, 1-in. ccSPF } \\
\text { (R-6) and 3.5-in. R-13 (GI) batt in band joists }\end{array}$ \\
\hline Overhanging Floors & $\mathrm{R}-40(\mathrm{G} 1)$ dense-pack fiberglass \\
\hline Roof & R-50 blown-in cellulose or fiberglass (GI); R-30 at eaves \\
\hline Exterior Doors & R-6 \\
\hline Windows & $\begin{array}{c}\text { Alpine windows, vinyl, double glazed with low-e. } \mathrm{U}<0.35 \text {, } \\
\text { solar heat gain coefficient }<0.30\end{array}$ \\
\hline Building Airtightness & Air changes per hour $(50)=3.1 ; \operatorname{CFM}(50)=2,725$ \\
\hline Mechanical Ventilation & $\begin{array}{c}\text { ASHRAE Standard } 62.2 \text { (ASHRAE 2013) exhaust only. } \\
\text { Panasonic FV-08VKS3 }\end{array}$ \\
\hline Heating & $93 \%$ AFUE \\
\hline Cooling & 13 seasonal energy efficiency ratio air conditioner optional \\
\hline Ductwork & 4 CFM/100 CFM@25 Pa, inside conditioned space \\
\hline Water Heater & $\begin{array}{l}\text { Bradford White \#BWM250T6DS 50-gal electric water heater } \\
\text { (0.92 energy factor) }\end{array}$ \\
\hline Appliances & $\begin{array}{c}\text { Dishwasher is ENERGY STAR; all other appliances are not } \\
\text { ENERGY STAR }\end{array}$ \\
\hline Fluorescent Lighting & $80 \%$ (minimum) compact fluorescent lamps \\
\hline Photovoltaic System & None \\
\hline
\end{tabular}

After reviewing the builder's standard for this floor plan, IBACOS provided three options to help the builder most directly approach ZERH performance levels because the builder's standard energy package was already high performing. The options included the following:

- Maintain all the standards in Table 2, but install a natural gas tankless water heater with an energy factor of 0.92 to yield a HERS Index of 56. The ZERH target index in this case is 60; therefore, this approach reaches ZERH performance.

- Maintain all the standards in Table 2, but install a natural gas tankless water heater with an energy factor of 0.62 to yield a HERS Index of 61. The ZERH target index in this case is 60; therefore, this approach falls just short of ZERH performance.

- Keep all the standards in Table 2, but install Alpine windows that are vinyl, double glazed with low-e, a U-value lower than 0.29 , and a solar heat gain coefficient lower than 0.30 to yield a HERS Index of 61. The ZERH target index in this case is 57; therefore, this approach falls just short of ZERH performance.

The proposed package of improvements was intended to integrate well with the builder's commitment to remain at the cutting edge of energy-efficient, high-quality construction and to be the regional leader in energy-efficient, green homebuilding. The overall goals of the ZERH 
design were to achieve increased energy savings, maintain acceptable levels of occupant comfort, and develop a flagship saleable product for the builder.

After IBACOS researched the upgrades that would be needed to move toward a ZERH package, the team walked through each upgrade with the builder. The builder raised some concerns about the potential costs that some of the upgrades would have over and above its standard product. The builder was not able to provide information about the costing implications of the upgrade and decided not to pursue ZERH production at this time; this effort was therefore truncated.

\subsection{Comfort Metrics}

The research team used two metrics to judge the comfort in each home: spatial uniformity and temporal (time-based) uniformity. According to ACCA Manual RS, the room-to-thermostat temperature variation in occupied space may not exceed $2^{\circ} \mathrm{F}$ during the heating season and $3^{\circ} \mathrm{F}$ during the cooling season (Rutkowski 1997). Also, the room-to-room temperature difference should be less than $4^{\circ} \mathrm{F}\left(2^{\circ} \mathrm{F}\right.$ average $)$ in the heating season and less than $6^{\circ} \mathrm{F}\left(4^{\circ} \mathrm{F}\right.$ average $)$ in the cooling season. This is called room-to-room temperature uniformity (or room-to-room $\Delta \mathrm{T}$ in this report) and is calculated as follows: For each timestamp, the temperature of the coolest room is subtracted from that of the warmest room to yield the room-to-room $\Delta \mathrm{T}$.

ASHRAE Standard 55 (ASHRAE 2010) outlines a range of acceptable temperature changes over time, as specified in Table 3 . If the temperature in a particular space changes more than the maximum value in each time interval, this is deemed to be a comfort concern. If a temperature change is caused by the HVAC system operation, it is deemed a "ramp" failure.

Table 3. ASHRAE Standard 55 Temperature Changes over Time ${ }^{a}$

\begin{tabular}{c|c|c|c|c|c}
\hline Time (min) & 15 & 30 & 60 & 120 & 240 \\
\hline Temperature $\Delta \mathrm{T}\left({ }^{\circ} \mathrm{F}\right)$ & $2^{\circ} \mathrm{F}$ & $3^{\circ} \mathrm{F}$ & $4^{\circ} \mathrm{F}$ & $5^{\circ} \mathrm{F}$ & $6^{\circ} \mathrm{F}$ \\
\hline${ }^{a}$ ASHRAE (2010).
\end{tabular}

A diagram of example ACCA and ASHRAE comfort failure modes is presented in Figure 23. As shown in this diagram, the top floor fails thermostat-to-room uniformity most of the time. During the peak temperature in the afternoon, the room-to-room temperature uniformity is beyond the $6^{\circ} \mathrm{F}$ boundary. A rapid decline in the temperature of the top floor may be deemed uncomfortable, according to ASHRAE Standard 55 (ASHRAE 2010). 


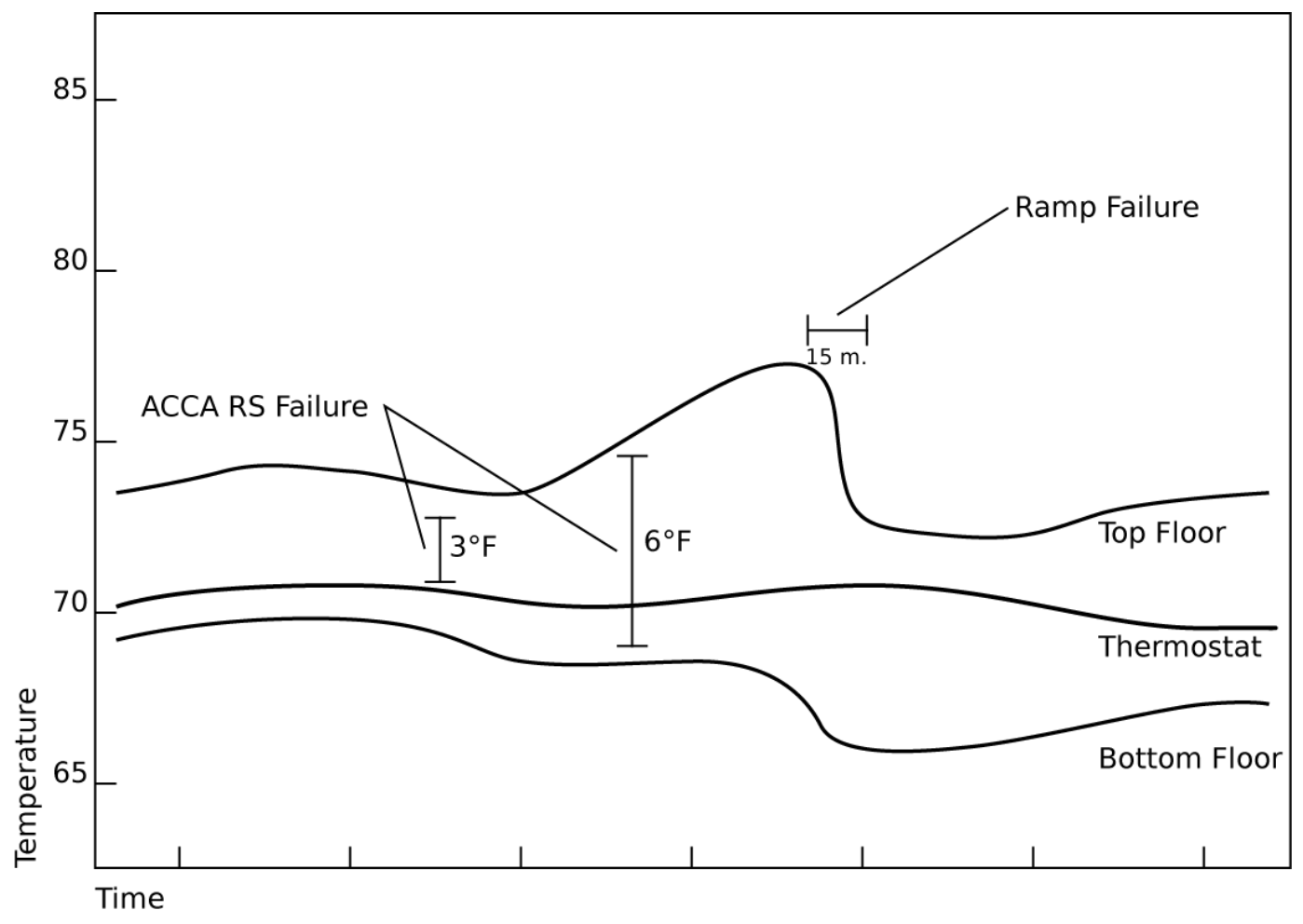

Figure 23. Diagram showing example ACCA Manual RS and drift/ramp failures (Rutkowski 1997)

Previous work by IBACOS (Poerschke and Beach 2015) showed that in 37 new homes in a hot and humid climate, occupants - even in the same community - used a distribution of set points. Performing a complete predicted mean vote calculation may not provide useful insight and could introduce a number of assumptions (e.g., air speed, metabolic rate, clothing level). For this reason, the team decided that thermal uniformity metrics provide better performance insight, especially when comparing multiple occupied test houses.

\subsection{Energy Use}

The initial plan was to measure the total electrical energy used by the Passive House, several end loads, and gas consumed by the hydronic coil's boiler. The team also planned to receive energy bills from the homeowner to supplement and reinforce these data. Throughout the project, the test monitoring equipment failed to deliver the expected performance and had to be replaced. No suitable replacement was found to provide electricity use measurements. The team also could not obtain utility bills that showed actual energy consumed, because the only data provided were for dollar amounts of bills. Furthermore, the Passive House has a photovoltaic system; as such, the electricity bill does not accurately capture the actual amount of energy used. 


\section{Research and Experimental Methods}

To help validate the performance of the Passive House, short-term performance tests were conducted after the home was constructed. EnergyLogic, Inc., ${ }^{11}$ an energy rater in Colorado, performed multiple short-term tests (Section 5.1). The data for these tests are presented for completeness due to interest from the national laboratories. Not all add to the builder knowledge base about Passive Houses. IBACOS also performed total system airflow tests on Control House 1 and Control House 2, and those data are presented.

To further validate the performance of the Passive House compared to that of Control House 1 and Control House 2, a long-term monitoring system was installed in each home to collect performance data throughout 1 year (Section 5.2).

\subsection{Short-Term Test Methods and Results}

To characterize the integrity of the thermal enclosure and to measure the start-up performance of the HVAC system, a number of short-term tests were completed after the Passive House was constructed. The following subsections describe these tests and their results. The total system airflow tests at the control houses also are included.

\subsubsection{Room-by-Room Supply Register Airflow}

The energy rater used a calibrated low-flow balometer to measure the airflow from each supply register in the Passive House. The rater then compared these measurements to the design airflow values from the ACCA Manual J heating and cooling load calculations (Rutkowski 2006) to determine if adequate airflow was reaching each zone.

Table 4 compares the contractor's design airflows to the measured airflows and reports the percent difference from the design. The measured values were taken in cooling mode, and the system was designed to use the same airflow for both heating and cooling modes (because a hydronic coil was used in heating mode). Measurements were taken after the HVAC contractor performed its final commissioning and represent the state of the house when it was purchased.

\footnotetext{
${ }^{11}$ EnergyLogic, Inc., Denver, CO, www.nrglogic.com/.
} 
Table 4. Room-by-Room Supply Register Airflows in the Passive House

\begin{tabular}{|c|c|c|c|}
\hline Location & $\begin{array}{c}\text { ACCA Manual D } \\
\text { Design Airflows }\end{array}$ & $\begin{array}{l}\text { Measured } \\
\text { Airflows }^{\mathrm{a}} \\
\end{array}$ & $\begin{array}{l}\% \text { Difference } \\
\text { from Design }\end{array}$ \\
\hline Basement & 92 & $\begin{array}{l}6 \\
8\end{array}$ & $\begin{array}{c}- \\
26 \\
\%\end{array}$ \\
\hline Great Room & 87 & $\begin{array}{l}9 \\
1\end{array}$ & $\begin{array}{l}+5 \\
\%\end{array}$ \\
\hline Foyer & 20 & $\begin{array}{l}2 \\
9\end{array}$ & $\begin{array}{l}+4 \\
5 \%\end{array}$ \\
\hline Nook & 81 & $\begin{array}{l}9 \\
1\end{array}$ & $\begin{array}{l}+1 \\
2 \%\end{array}$ \\
\hline Kitchen & 60 & $\begin{array}{l}5 \\
0\end{array}$ & $\begin{array}{l}- \\
17 \\
\%\end{array}$ \\
\hline Project Room & 80 & $\begin{array}{l}1 \\
0 \\
4\end{array}$ & $\begin{array}{l}+3 \\
0 \%\end{array}$ \\
\hline Bedroom 3 & 63 & $\begin{array}{l}8 \\
2\end{array}$ & $\begin{array}{l}+3 \\
0 \%\end{array}$ \\
\hline Bedroom 2 & 67 & $\begin{array}{l}7 \\
8\end{array}$ & $\begin{array}{l}+1 \\
6 \%\end{array}$ \\
\hline Bath 2 & 30 & $\begin{array}{l}7 \\
5\end{array}$ & $\begin{array}{l}+1 \\
50 \\
\%\end{array}$ \\
\hline Hall 2 & 40 & $\begin{array}{l}3 \\
8\end{array}$ & $\begin{array}{c}- \\
5 \%\end{array}$ \\
\hline Laundry & 52 & $\begin{array}{l}7 \\
6\end{array}$ & $\begin{array}{l}+4 \\
6 \%\end{array}$ \\
\hline First-Floor Total & 328 & $\begin{array}{l}3 \\
6 \\
5\end{array}$ & $\begin{array}{l}+1 \\
1 \%\end{array}$ \\
\hline Second-Floor Total & 395 & $\begin{array}{l}5 \\
1 \\
8\end{array}$ & $\begin{array}{l}+3 \\
1 \%\end{array}$ \\
\hline Total & 815 & $\begin{array}{l}9 \\
5 \\
1\end{array}$ & $\begin{array}{l}+1 \\
7 \%\end{array}$ \\
\hline
\end{tabular}

${ }^{a}$ EnergyLogic used an Alnor LoFlo Balometer (Model 6200) with a $\pm 3 \%$ accuracy for testing this house. The \pm number would account for that accuracy percentage. 


\subsubsection{Duct Air Leakage}

The duct air leakage for the Passive House was measured using a Minneapolis Duct Blaster. ${ }^{12}$ Total air leakage through the duct systems and to the outside was measured. The amount of air leaking through the duct system helped to characterize the performance of the air distribution system capacity for delivering the proper amount of air to the zones of the house. The total duct leakage was 38 CFM.

\subsubsection{Whole-Building Air Leakage}

To evaluate the airtightness performance of the building enclosure, a test using a blower door was conducted after the Passive House was constructed. The test measures the amount of air leaking through the enclosure under a known operating pressure differential between the house and the outside. The target test result is $0.60 \mathrm{ACH} 50$, which is the maximum for Passive House certification. The builder's HERS rater performed a whole-building air leakage test, and Table 5 shows the test results.

Table 5. Final Whole-House Air Leakage for the Passive House

\begin{tabular}{c|c|c}
\hline Performance Metric & Value & Units \\
\hline House Size & 3,267 & Square feet of finished floor area \\
\hline House Volume & 32,352 & Cubic feet \\
Whole-House Air Leakage & 324.5 & CFM50 \\
& 0.60 & ACH50 \\
\hline
\end{tabular}

\subsubsection{Room Pressures}

A digital manometer from The Energy Conservatory ${ }^{13}$ was used to measure the static pressure developed between each bedroom and the central space of the Passive House while the HVAC system was operating. Table 6 shows the results of these tests.

Table 6. Passive House Room Pressurization

\begin{tabular}{c|c}
\hline Room & $\begin{array}{c}\text { Pressure Reading from Bedroom Space to } \\
\text { Central Space of House with HVAC } \\
\text { System On }\end{array}$ \\
\hline Master Bedroom & $+0.2 \mathrm{~Pa}$ \\
\hline Bedroom 3 & $+0.2 \mathrm{~Pa}$ \\
Bedroom 4 & $+0.6 \mathrm{~Pa}$ \\
\hline
\end{tabular}

\subsubsection{Energy Recovery Ventilator Airflow Balancing}

Fresh air is supplied to the Passive House by a Zehnder ComfoAir $350^{14}$ ERV unit installed on the second floor in the laundry room. The ERV operates continuously and supplies the house with 74 CFM of fresh air. To help verify that this ERV unit is supplying the proper amount of air to the house, the airflow was measured after the unit was installed. Measurements were

\footnotetext{
${ }^{12}$ Minneapolis Duct Blaster. Minneapolis, MN: The Energy Conservatory, http://products.energyconservatory.com/minneapolis-duct-blaster-system.

${ }^{13}$ The Energy Conservatory. Minneapolis, MN, www.energyconservatory.com/products.

${ }^{14}$ Zehnder ComfoAir 350. Greenland, NH: Zehnder America, www.zehnderamerica.com/products/product list.aspx?CategoryID=1.
} 
performed using a flow gauge (manometer) manufactured by The Energy Conservatory. ${ }^{15}$ The estimated airflow for the ERV unit using a manometer during the cooling season is $114 \mathrm{CFM}$ as measured in the utility room. The estimate seems to show that the air delivery is higher than necessary. The measurement method does not provide for a highly accurate reading.

\subsubsection{Total System Airflow Test}

IBACOS performed a total system airflow test for the air handling units in Control House 1 and Control House 2; the data are presented in Table 7. The team followed the test equipment manufacturer's procedure to use a TrueFlow plate $( \pm 7 \%)$ and DG $700( \pm 1 \%)$ pressure and flow gauge (shown in Figure 24). The baseline static pressure in the supply plenum was first measured with the filter installed. Then the test equipment software automatically accounted for any change in plenum pressure once the flow plate was installed. Because this test was performed in winter, only airflow from heating mode could be collected to avoid damage to the airconditioning compressor.

Table 7. Total System Airflow Measurements for the Control Houses

\begin{tabular}{c|c}
\hline & Total System Airflow (Heating) \\
\hline Control House 1 & $1,090 \mathrm{CFM}$ \\
Control House 2 & $1,000 \mathrm{CFM}$ \\
\hline
\end{tabular}

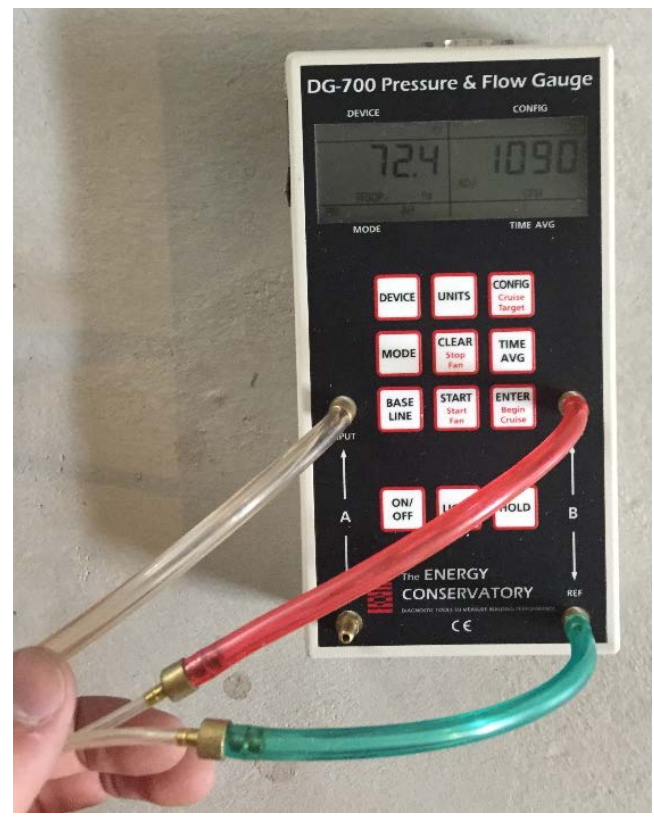

Figure 24. DG-700 used to measure total system airflow

\subsection{Long-Term Monitoring and Data Collection}

\subsubsection{Passive House}

The Passive House was sold in late January 2014, and the homeowners moved in at that time. On February 1, 2014, IBACOS installed long-term monitoring equipment. This equipment collected data until February 2015 about the performance of key subsystems.

\footnotetext{
${ }^{15}$ The Energy Conservatory. Minneapolis, MN, www.energyconservatory.com/products.
} 
The primary objectives of monitoring included collection of temperature and relative humidity data from individual rooms and thermal zones in the house and outside.

Appendix D contains diagrams of the monitoring system design, including sensor locations and data that were collected during long-term monitoring.

During the construction of each house, monitoring wiring was installed by an electrician and the project team, and the project team commissioned the monitoring equipment after construction was complete. A combination of wired and wireless sensors was used to capture the needed data and minimize installation labor. Appendix D also lists the long-term monitoring equipment installed in this Passive House. Figure 25 through Figure 27 show examples of installed monitoring equipment.

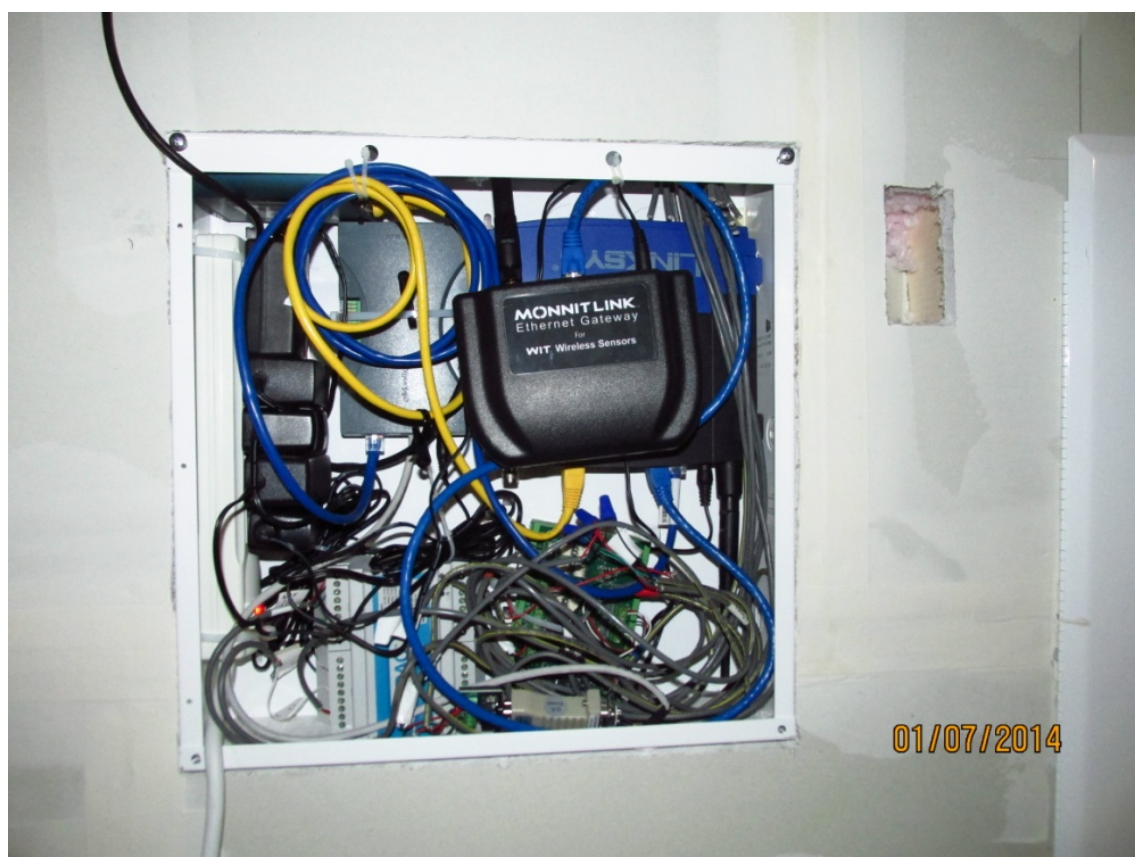

Figure 25. Data logging control center in the basement of the Passive House 


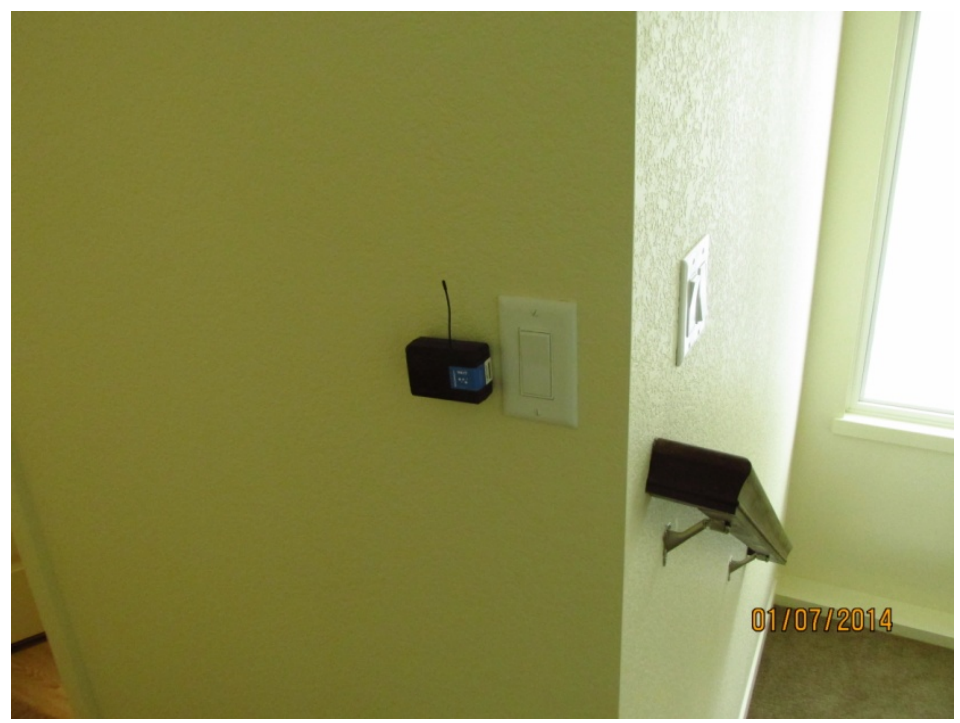

Figure 26. Wireless temperature and relative humidity sensor location on the second floor of the Passive House

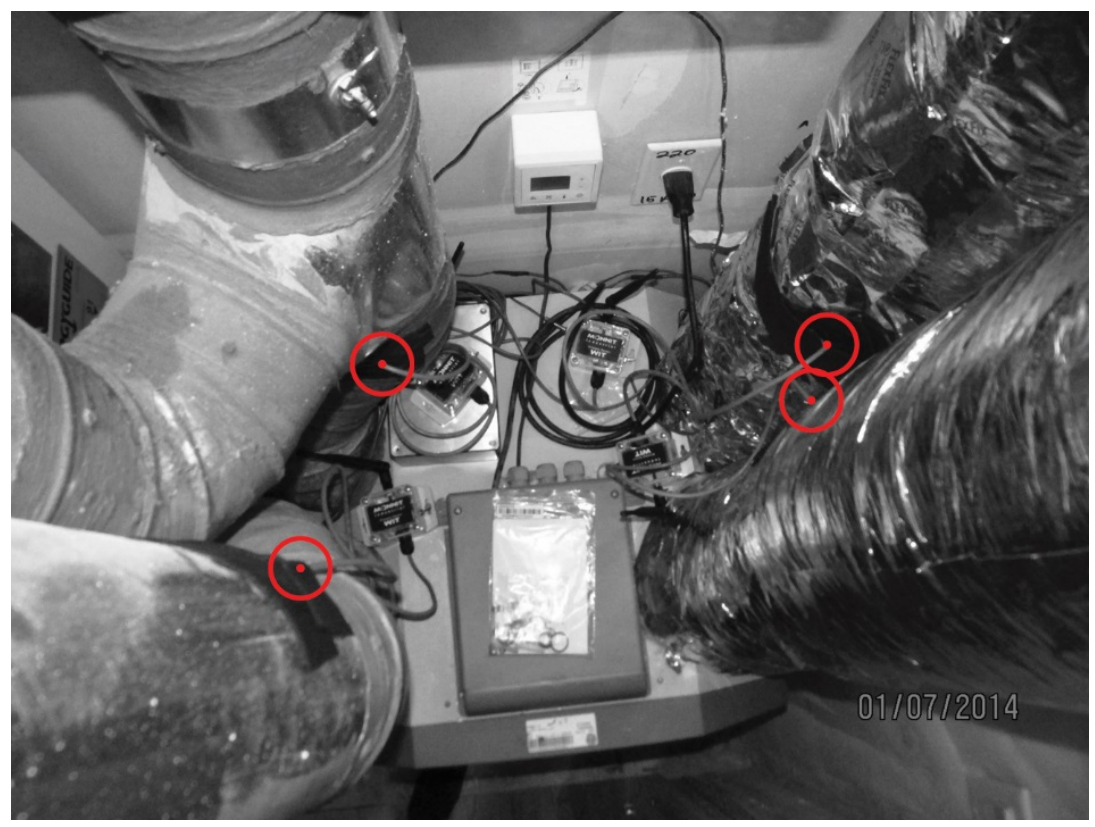

Figure 27. ERV sensor location in the second-floor mechanical closet of the Passive House

One issue that the project team had to overcome was measuring the electrical energy consumed in the Passive House. Initially, a consumer-oriented data collection system was installed to test its abilities. It quickly became apparent this system was not up to the challenge of collecting research-grade measurements, and the system had to be replaced. Because of complications, the team was unable to collect electrical energy measurements from the Passive House. Air handling system runtime was inferred from plenum temperatures, as described in Section 6.2. 
Using non-research-grade equipment also resulted in losing periods of data when the cellular modem went down. The modem did not have sufficient local storage or an automated way to restart the server connection.

\subsubsection{Control Houses}

Long-term monitoring equipment was installed in both control houses during January and February 2014 to align with the completion of the house construction. Monnit wireless sensors were used to measure the temperature in each room and a mixture of wired and wireless sensors for the remaining measurement locations. A Monnit cellular gateway originally was installed in Control House 1, and a Campbell Scientific CR1000 was used to log and transmit data in Control House 2. A complete list of sensors and sensor locations for both control houses is included in Appendix D.

In August 2014, the Monnit cellular gateway was replaced with a Campbell Scientific CR1000 in Control House 1 and the Passive House. This was due to data loss associated with the cellular connection and difficulty in obtaining a complete set of 1-min interval data from the iMonnit database software.

Ultimately, the data used in this report were collected using Monnit wireless sensors and a CR1000 data logger with a cellular connection in each house. A "Serial Modbus Gateway" supplied by Monnit allowed the CR1000 to interface with the wireless sensors. This setup played to the strengths of the wireless sensors, which were easy to install, and offered battery-powered operation using a 1-min data interval for 1 year. The robustness of the telemetry capabilities of the CR1000 then were leveraged to store and transmit data.

\subsection{Zero Energy Ready Home Technical Approach}

For the design of a ZERH specification package, as part of the companion effort, REM/Rate Version 14.4 was used to model and evaluate a variety of options for meeting the performance path target for ZERH compliance. IBACOS and the builder reviewed these specification packages, and the builder provided feedback about the feasibility of building homes to these various specifications in the Brighton Heights area of Denver, Colorado.

\subsection{Calculating System Runtime}

Runtime periods in heating and cooling for all three test homes were estimated from temperature measurements taken at the supply and return plenum. This was due to a failure in the initial plan to measure the electrical energy consumed by the air handling unit in the Passive House. The team decided it was best to use a consistent data source across homes, so all three sets of runtime data are based off the supply temperature.

First, the data set was split into periods at each inflection point in the supply temperature data. At the end of each period, the temperature difference between the supply and return was used to determine if the system was on during the period. Figure 28 illustrates a single day with the supply temperature, with highlights indicating the system was determined to be on. 


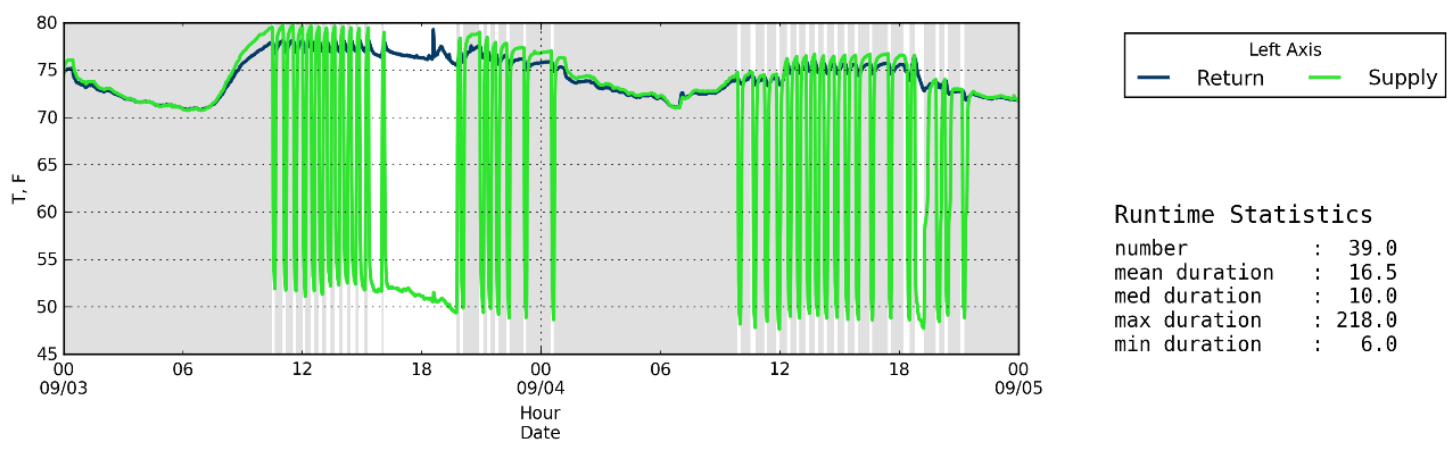

Figure 28. Calculated runtime of HVAC equipment highlighted in white

This calculation is somewhat uncertain, because only a simple threshold was used at the end of each period. Periods during which the system was on would have been skipped if the system did not run long enough for the supply temperature to exceed the temperature threshold. In the case of the Passive House, the threshold was set at a difference of $30^{\circ} \mathrm{F}$. Periods during which the system was off may have been included as system runtime if the temperature in the supply between the periods did not fall below the threshold.

The team compared the runtime determined from electrical energy to the runtime determined from supply temperature for September. Control House 1 showed 7,573 min of runtime based on electricity measurements and 8,243 min of runtime based on supply temperature, for a $9.4 \%$ difference. Control House 2 showed 3,975 min of runtime based on electricity measurements and 3,410 min of runtime based on supply temperature, for a $14 \%$ difference. 


\section{Long-Term Monitoring Results}

Measured results are presented to inform the responses to the project's research questions. Data from each of the three test houses are presented first. Then additional detailed analysis is presented for the Passive House.

Two representative periods of 2 days were selected for detailed analysis. The weather data during these periods are shown in Figure 29 and Figure 30. The cooling data presented are from one very hot and sunny day and one warm and less sunny day (September 3 and September 4, 2014). The heating data show one very cold and cloudy day and one slightly warmer and sunnier day (November 12 and November 13, 2014). These variations are important when considering the impact of extreme temperatures relative to milder temperatures and the impact of solar radiation.

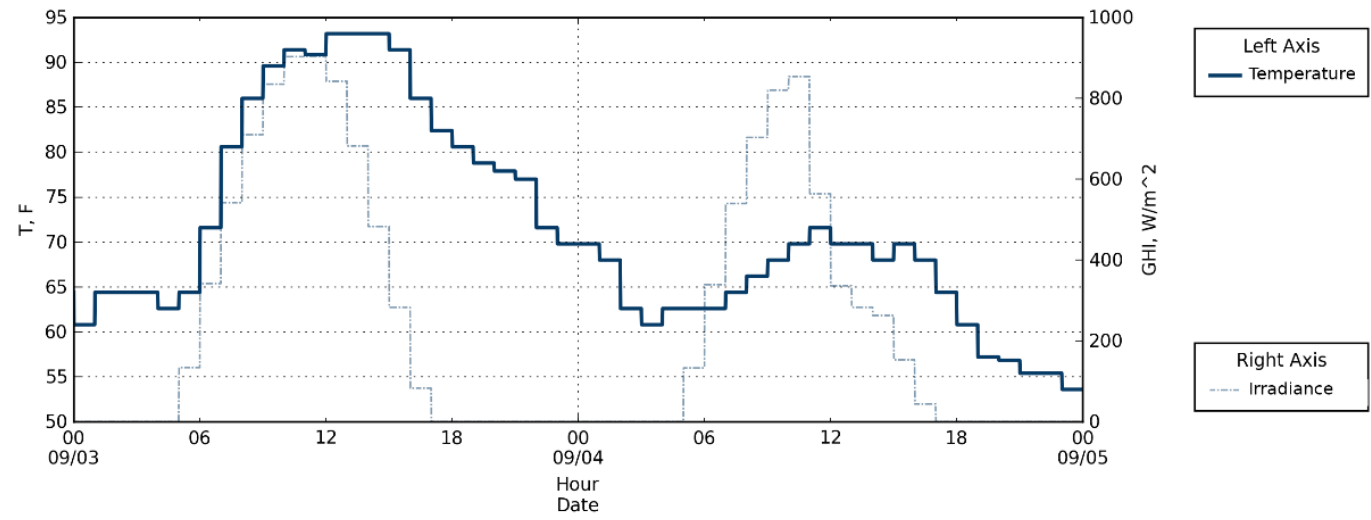

Figure 29. Outdoor temperature and solar irradiance at the test site for the cooling period

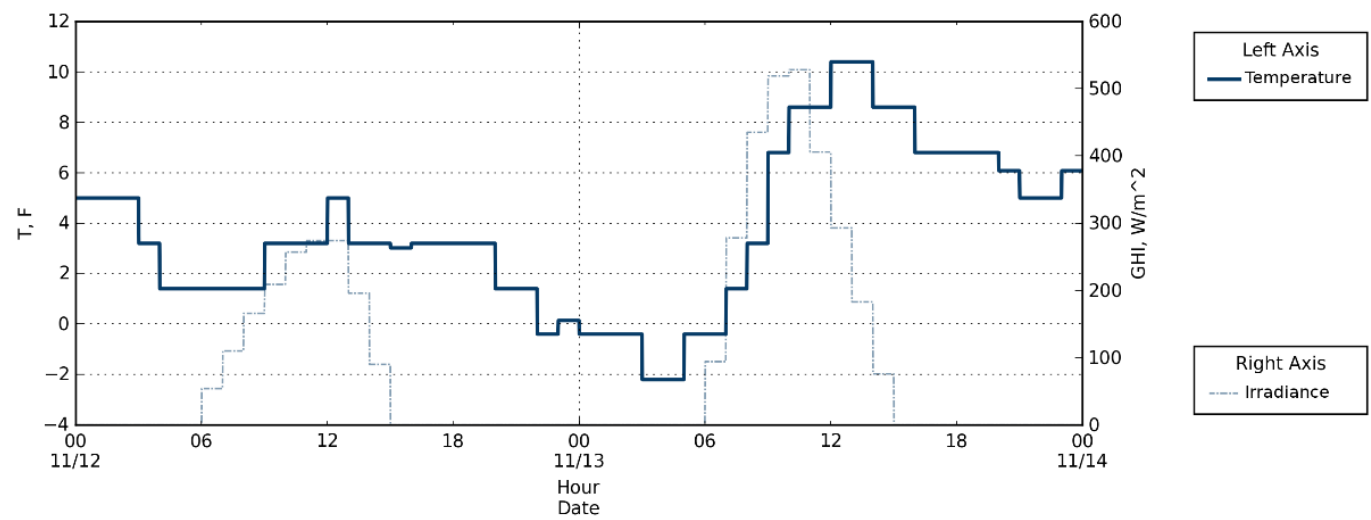

Figure 30. Outdoor temperature and solar irradiance at the test site for the heating period

\subsection{Room-to-Room Temperature Uniformity and System Runtime}

The room-to-room temperature difference was calculated to provide a basic understanding of the relative comfort performance of each control house versus the Passive House by subtracting the temperature in the coolest room from that of the warmest room for each minute, always yielding 
a number greater than or equal to 0 . As stated earlier, ACCA suggests that the room-to-room temperature difference should be less than $4^{\circ} \mathrm{F}$ during the heating season and $6^{\circ} \mathrm{F}$ during the cooling season. As an example below, 2 days were selected to represent the cooling season (September 3 and 4, 2014), and 2 days were selected to represent the heating season (November 13 and 14, 2014). Furthermore, a scatter plot was created that uses all measured data to show the comparative relationships between the daily average outdoor temperature and the daily average room-to-room temperature difference for each house (Figure 31).

A number of statistics calculated for each day of the cooling season analysis are presented in Table 8 and Figure 31. A lower room-to-room temperature difference indicates a betterperforming house and HVAC system. The standard deviation provides a better understanding of the daily variability in each house. A low standard deviation indicates a uniform trend among the temperatures in each house.

Table 8. Daily Room-to-Room Temperature Difference Statistics-Cooling ( $\left.{ }^{\circ} \mathrm{F}\right)$

\begin{tabular}{c|c|c|c|c|c|c}
\hline & \multicolumn{2}{|c|}{ Passive House } & \multicolumn{2}{c|}{ Control House 1 } & \multicolumn{2}{c}{ Control House 2 } \\
\hline Date & $9 / 3 / 2014$ & $9 / 4 / 2014$ & $9 / 3 / 2014$ & $9 / 4 / 2014$ & $9 / 3 / 2014$ & $9 / 4 / 2014$ \\
\hline Average & 5.1 & 5.1 & 8.3 & 8.1 & 7.9 & 7.3 \\
\hline $\begin{array}{c}\text { Standard } \\
\text { Deviation }\end{array}$ & 0.3 & 0.5 & 2.0 & 0.6 & 1.4 & 0.9 \\
Minimum & 4.5 & 3.9 & 5.7 & 7.2 & 5.4 & 5.5 \\
Maximum & 5.0 & 5.1 & 8.1 & 8.0 & 8.0 & 7.1 \\
$\begin{array}{c}\text { Average Outdoor } \\
\left.\text { Temperature }{ }^{\circ} \mathbf{F}\right)\end{array}$ & 78 & 64 & 78 & 64 & 78 & 64 \\
\hline
\end{tabular}




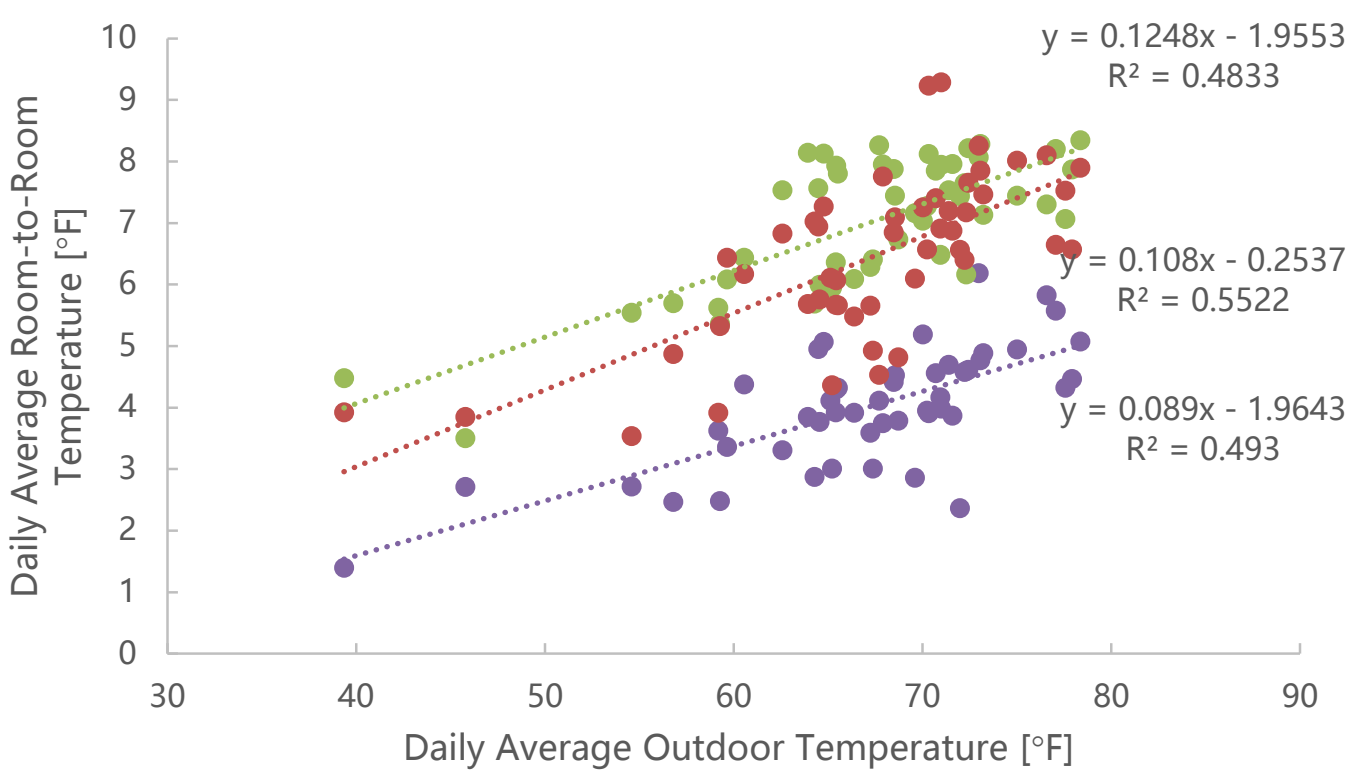

- Passive House - Control House 1 - Control House 2

Figure 31. Daily average room-to-room temperature differences versus outdoor temperaturesrepresentative cooling period

In Figure 31, the daily average room-to-room temperature was plotted against the daily average outdoor temperature for the period of August 8 through September 25, 2014. This plot shows data from each of the three houses during cooling and provides an understanding of temperature dynamics under different conditions. Two days had cold snaps with the average temperature lower than $50^{\circ} \mathrm{F}$, which is not unexpected for late summer in Denver. Linear regressions are in the plot. The relatively low $\mathrm{R}^{2}$ value suggests a number of factors beyond the outdoor temperature are influencing room-to-room temperatures.

Data from 2 representative cold days of the heating season are presented in Table 9.

Table 9. Daily Room-to-Room Temperature Difference Statistics-Heating $\left({ }^{\circ} \mathrm{F}\right)$

\begin{tabular}{c|c|c|c|c|c|c}
\hline & \multicolumn{2}{|c|}{ Passive House } & \multicolumn{2}{c|}{ Control House 1 } & \multicolumn{2}{c}{ Control House 2 } \\
\hline Date & $11 / 12 / 2014$ & $11 / 13 / 2014$ & $11 / 12 / 2014$ & $11 / 13 / 2014$ & $11 / 12 / 2014$ & $11 / 13 / 2014$ \\
\hline Average & 3.7 & 4.7 & 7.5 & 8.2 & 5.9 & 6.5 \\
$\begin{array}{c}\text { Standard } \\
\text { Deviation }\end{array}$ & 0.5 & 0.6 & 0.2 & 0.5 & 1.6 & 0.5 \\
Minimum & 2.6 & 3.3 & 6.9 & 7.2 & 3.8 & 5.5 \\
$\begin{array}{c}\text { Maximum } \\
\begin{array}{c}\text { Average } \\
\text { Outdoor }\end{array}\end{array}$ & 3.5 & 4.8 & 7.5 & 8.2 & 5.8 & 6.5 \\
$\begin{array}{c}\text { Temperature } \\
\left({ }^{\circ} \text { F) }\right.\end{array}$ & 2.9 & 4.3 & 2.9 & 4.3 & 2.9 & 4.3 \\
\hline
\end{tabular}


In Figure 32, the average room-to-room temperature was plotted against the average outdoor temperature for the period of November 11, 2014, through January 13, 2015.

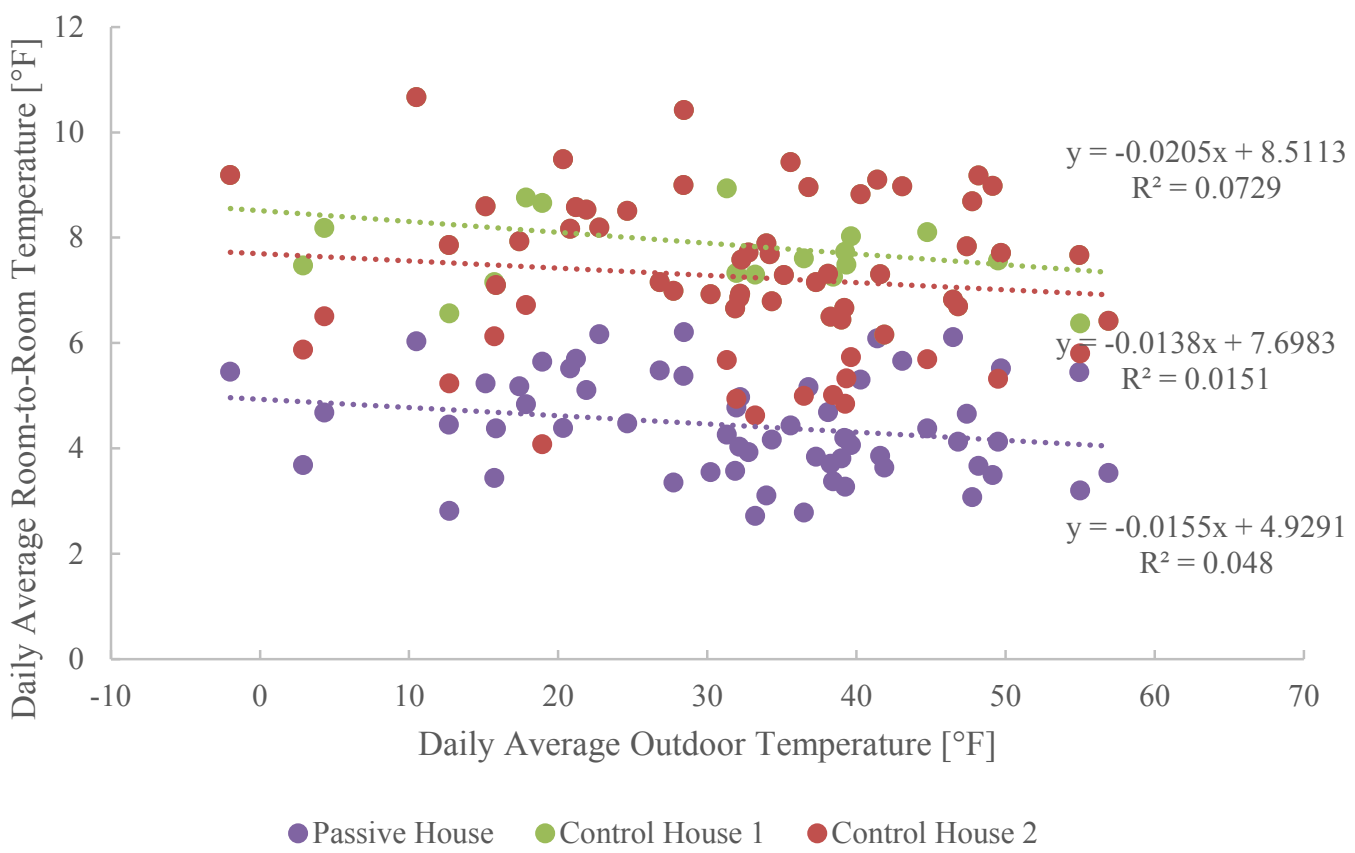

Figure 32. Daily average room-to-room temperature differences versus outdoor temperaturesrepresentative heating period

For each of the three houses in this study, the team created a plot containing four subplots, as follows:

- The first subplot shows room-to-thermostat temperature differences.

- The second subplot shows the room air temperatures.

- The third subplot shows the room relative humidities presented as fractions (e.g., 50\%).

- The fourth subplot shows the supply and return plenum air temperature.

In each plot, periods when the system was off are shaded in gray, and periods when the system was on are shown as white. The floor where each zone is located also is indicated in the legend. Calculated runtime statistics are printed on each figure. Consistent measurements of the power consumed by the air handling units were not available for the duration of the study. Therefore, the project team used an algorithm to determine system runtime based on the temperature difference from the supply to the return air plenum, as explained in previous sections.

Figure 33 through Figure 35 show data from the cooling season; Figure 36 through Figure 38 show data from the heating season. Section 6.2 provides a discussion related to data presented in this section. 

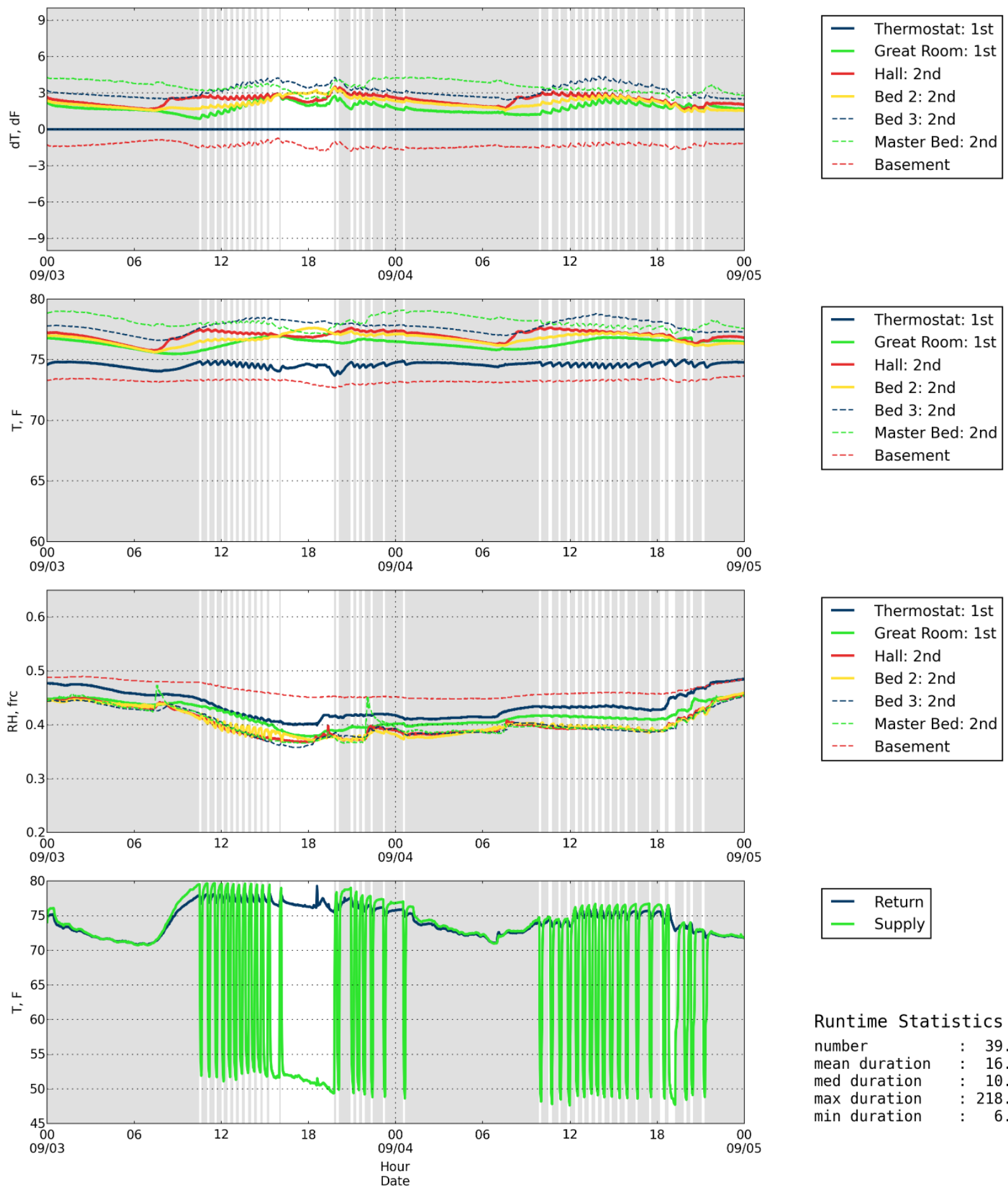

Figure 33. Passive House-cooling mode-room temperatures and system operation

Runtime Statistics

number : 39.0

mean duration: 16.5

med duration : 10.0

max duration : 218.0

min duration : 6.0 

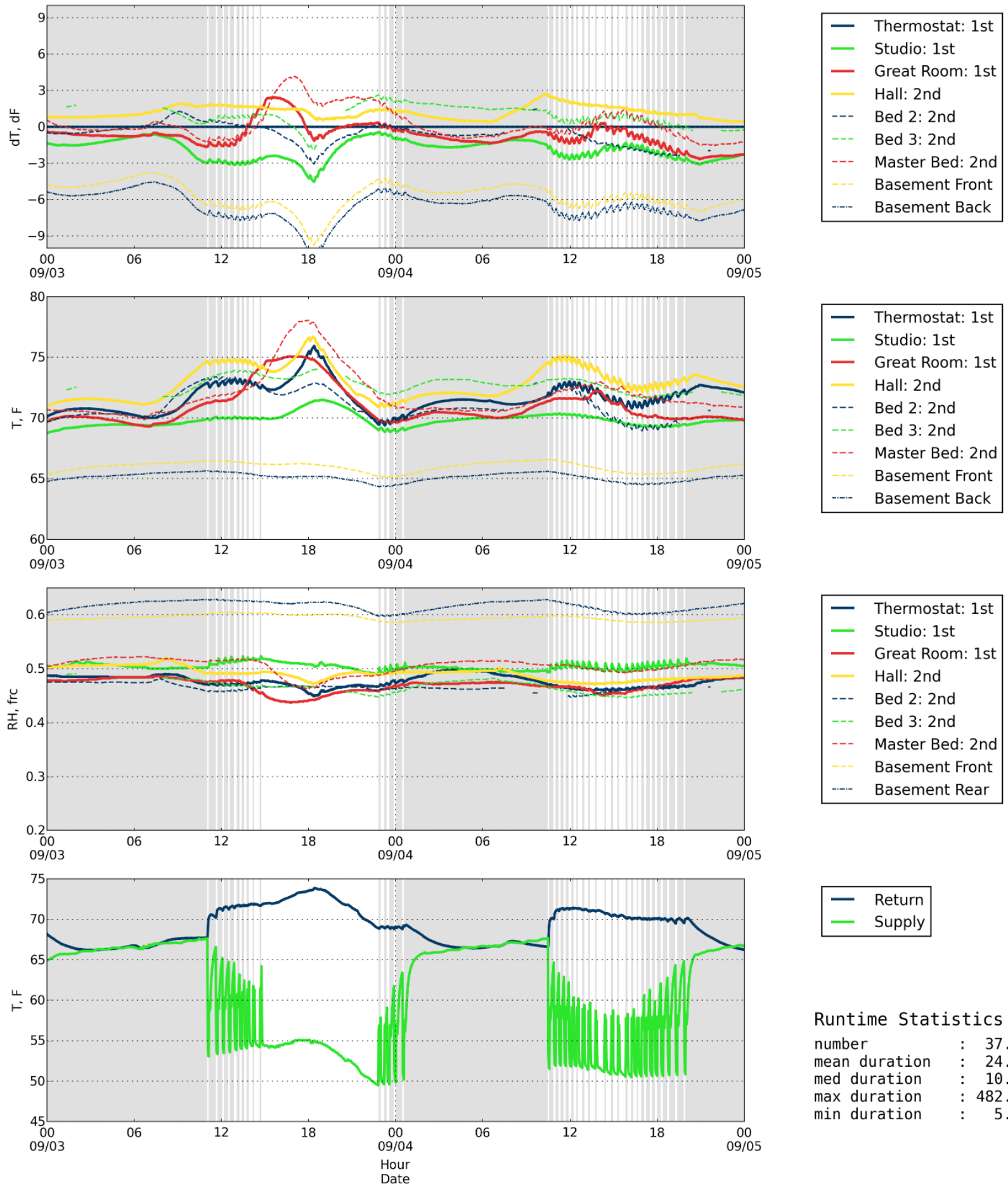

Figure 34. Control House 1-cooling mode-room temperatures and system operation

Runtime Statistics

number : 37.0

mean duration: 24.5

med duration : 10.0

max duration : 482.0

min duration : 5.0 


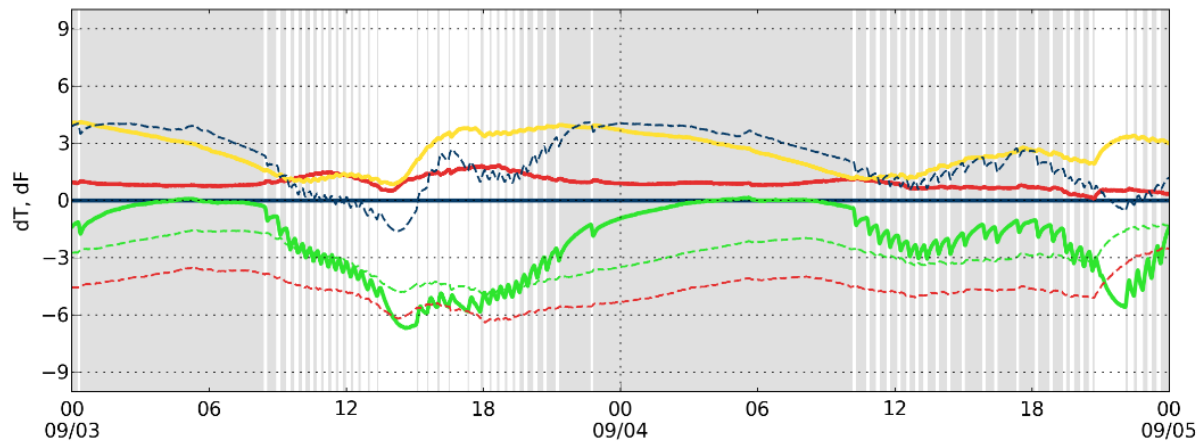

$\begin{array}{ll}- & \text { Thermostat: 1st } \\ - & \text { Studio: 1st } \\ - & \text { Great Room: 1st } \\ - & \text { Bed 2: 2nd } \\ --- & \text { Master Bed: 2nd } \\ --- & \text { Basement Front } \\ --- & \text { Basement Back }\end{array}$
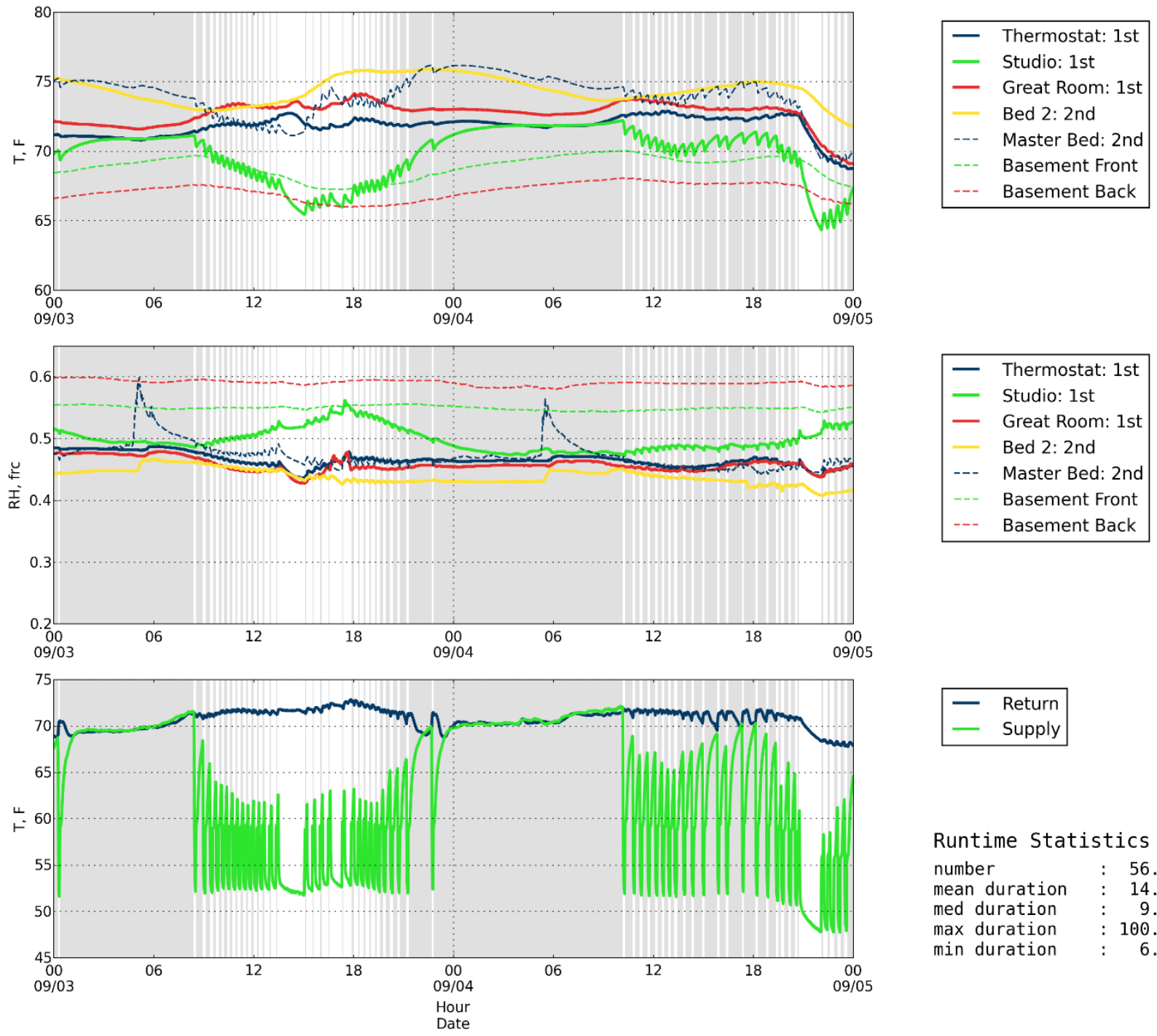

Figure 35. Control House 2-cooling mode-room temperatures and system operation

Runtime Statistics

number : 56.0 mean duration : 14.6 med duration: 9.5 $\max$ duration : 100.0 min duration: 6.0 

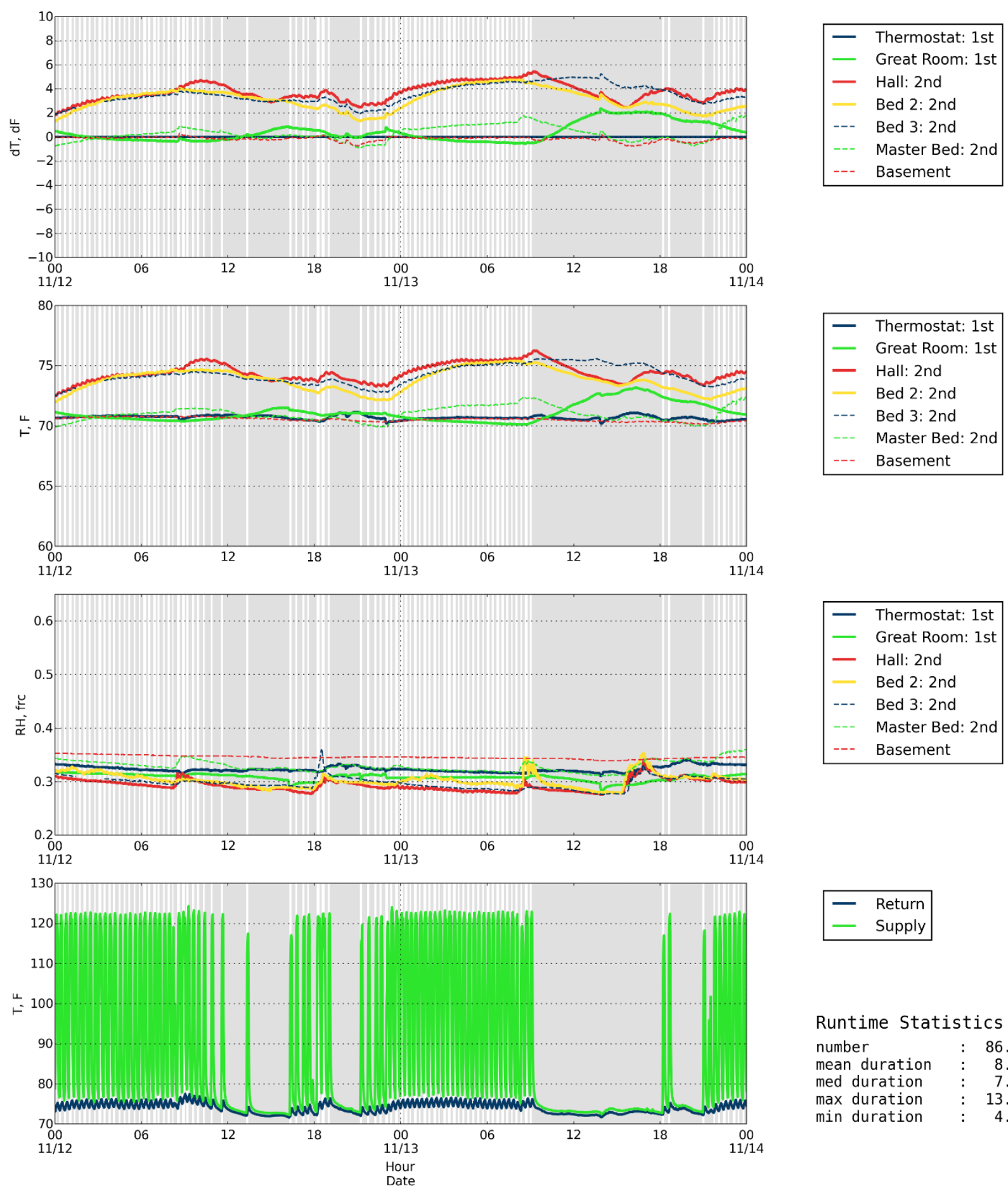

Figure 36. Passive House-heating mode-room temperatures and system operation 

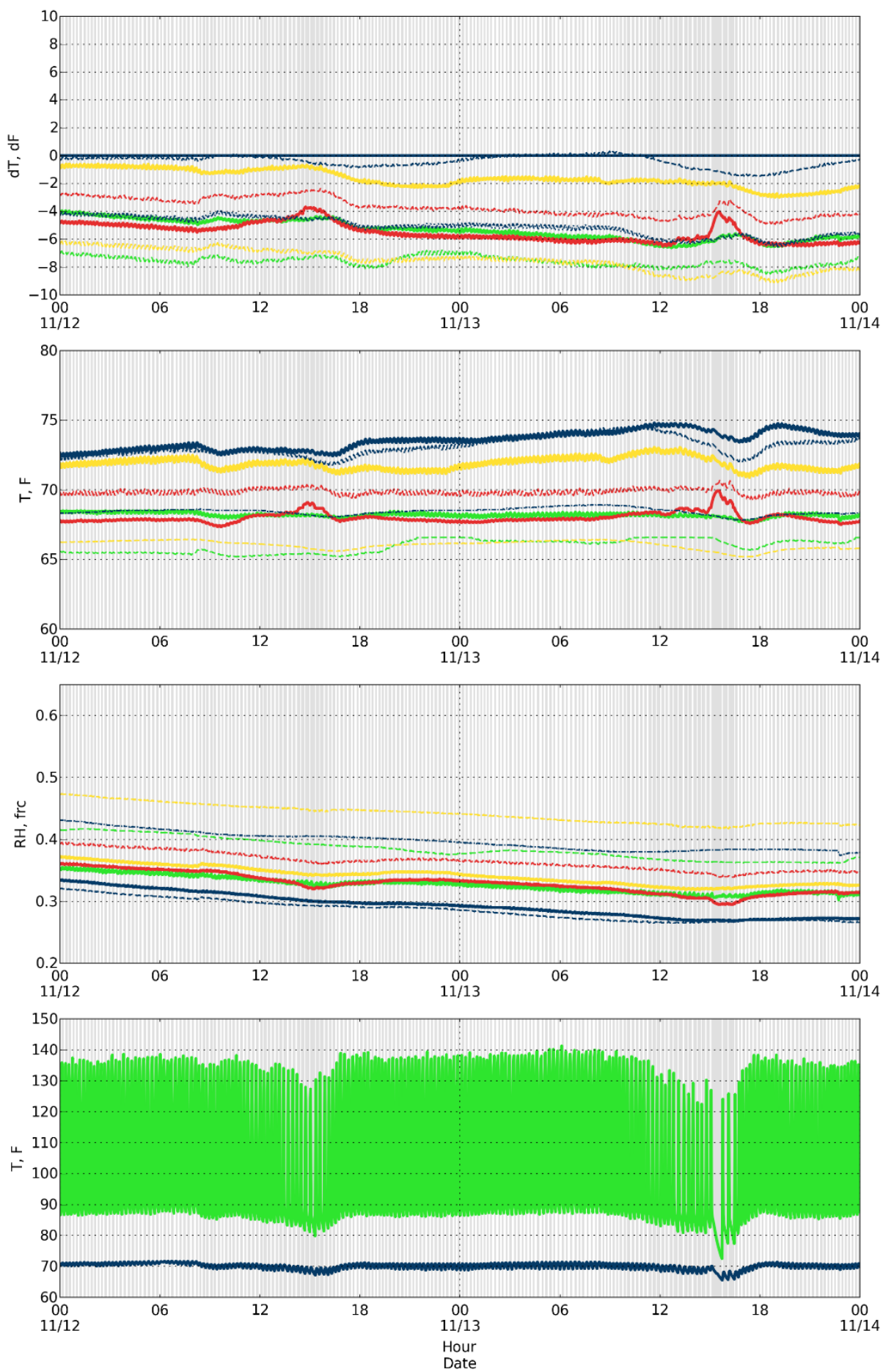

$\begin{array}{ll}- & \text { Thermostat: 1st } \\ - & \text { Studio: 1st } \\ - & \text { Great Room: 1st } \\ & \text { Hall: 2nd } \\ --- & \text { Bed 2: 2nd } \\ --- & \text { Bed 3: 2nd } \\ --- & \text { Master Bed: 2nd } \\ - & \text { Basement Front } \\ --- & \text { Basement Back }\end{array}$

$\begin{array}{ll}- & \text { Thermostat: 1st } \\ - & \text { Studio: 1st } \\ - & \text { Great Room: 1st } \\ - & \text { Hall: 2nd } \\ --- & \text { Bed 2: 2nd } \\ --- & \text { Bed 3: 2nd } \\ --- & \text { Master Bed: 2nd } \\ - & \text { Basement Front } \\ ---- & \text { Basement Back }\end{array}$

$\begin{array}{ll}- & \text { Thermostat: 1st } \\ - & \text { Studio: 1st } \\ - & \text { Great Room: 1st } \\ & \text { Hall: 2nd } \\ --- & \text { Bed 2: 2nd } \\ --- & \text { Bed 3: 2nd } \\ --- & \text { Master Bed: 2nd } \\ - & \text { Basement Front } \\ ---- & \text { Basement Rear }\end{array}$

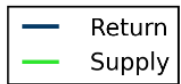

Runtime Statistics

number

: 202.0

mean duration : 4.8

med duration : 5.0

max duration : 7.0

min duration : 2.0

Figure 37. Control House 1-heating mode-room temperatures and system operation 

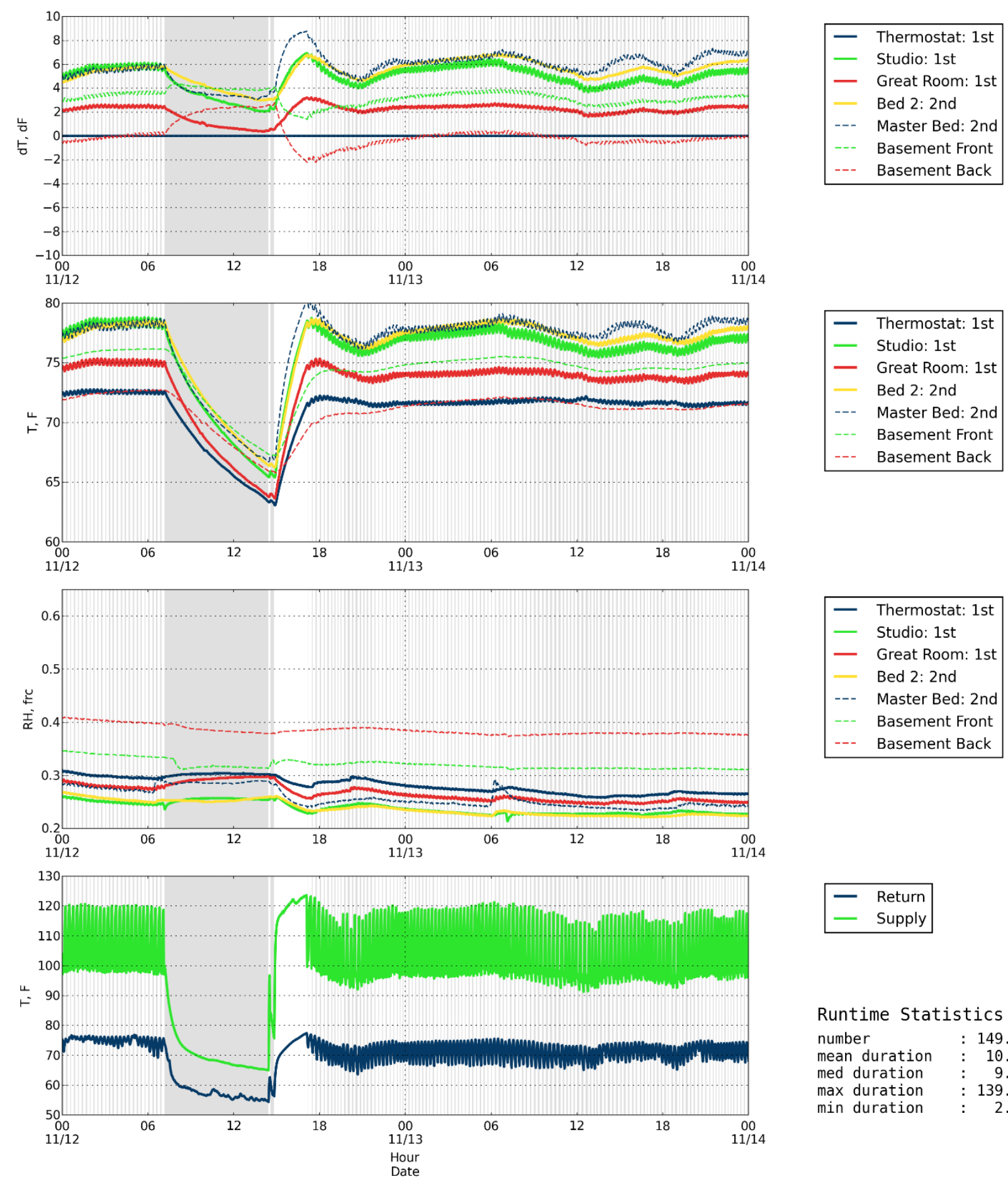

Figure 38. Control House 2-heating mode-room temperatures and system operation

To provide further understanding of the temporal behavior of each house in this study, the team created a heat map for each house, with the date on the vertical axis and the hour of the day on the horizontal axis. Data then are represented as shaded cells according to the legend. Periods of missing data are represented in gray. The plot shows the total system runtime in each hour and 
minute-by-minute thermostat temperature measurement. Figure 39 and Figure 40 show system runtime and the temperature at the thermostat for cooling mode; Figure 41 and Figure 42 show the same data for heating mode. Note that Control House 1 did not have runtime measurements for heating mode.
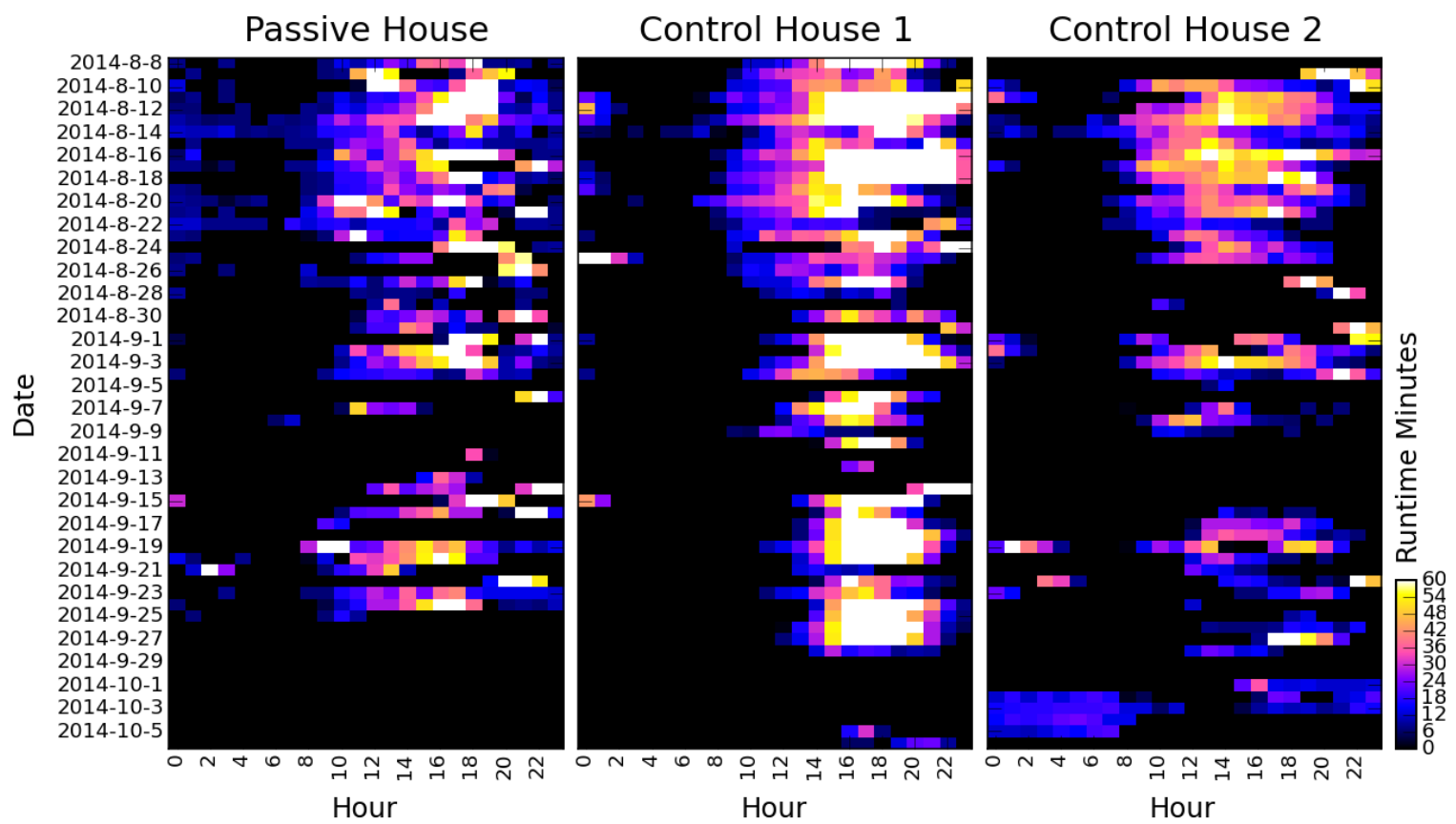

Figure 39. Heat map of system runtime-cooling mode
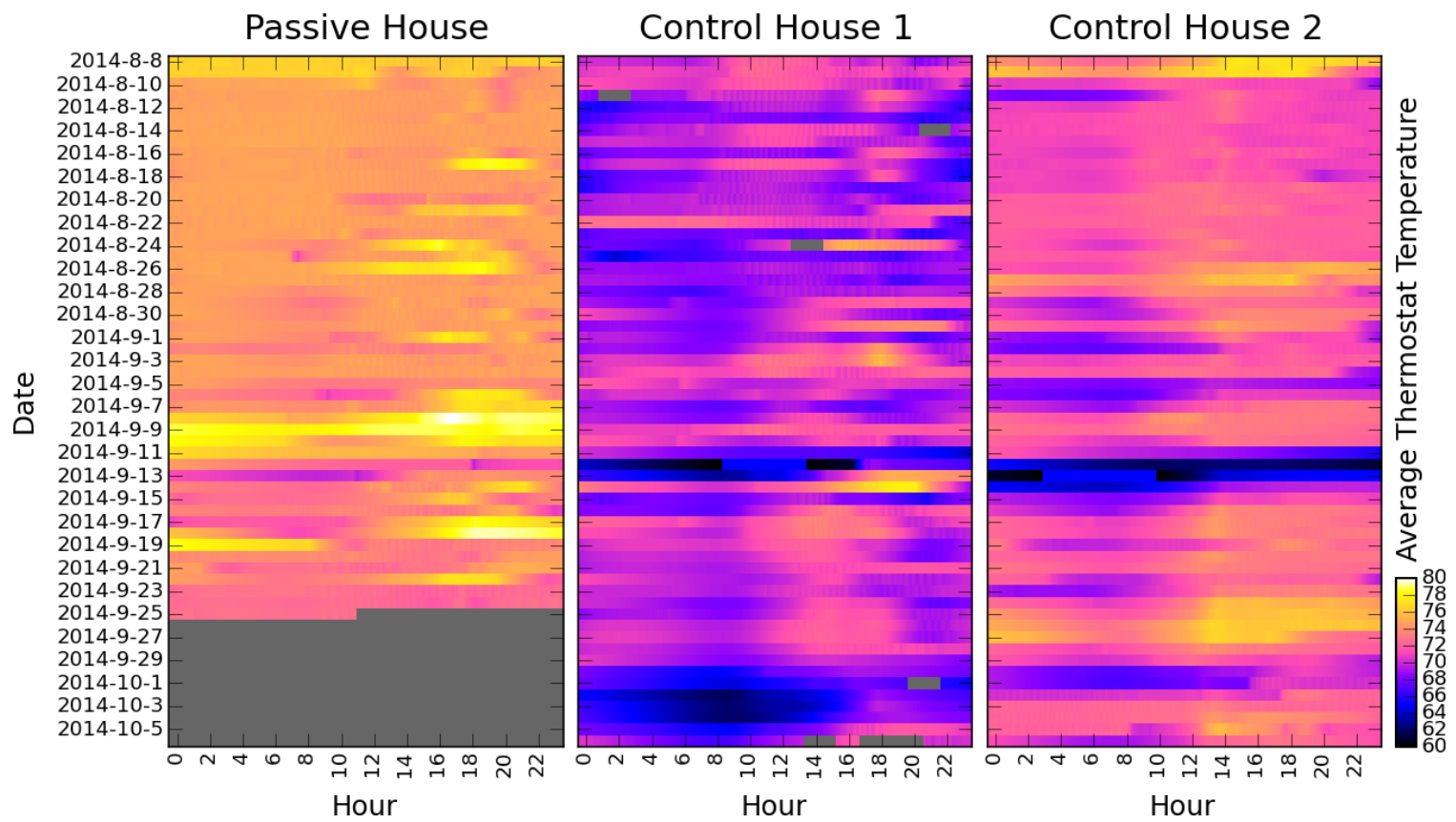

Figure 40. Heat map of thermostat temperature-cooling mode 


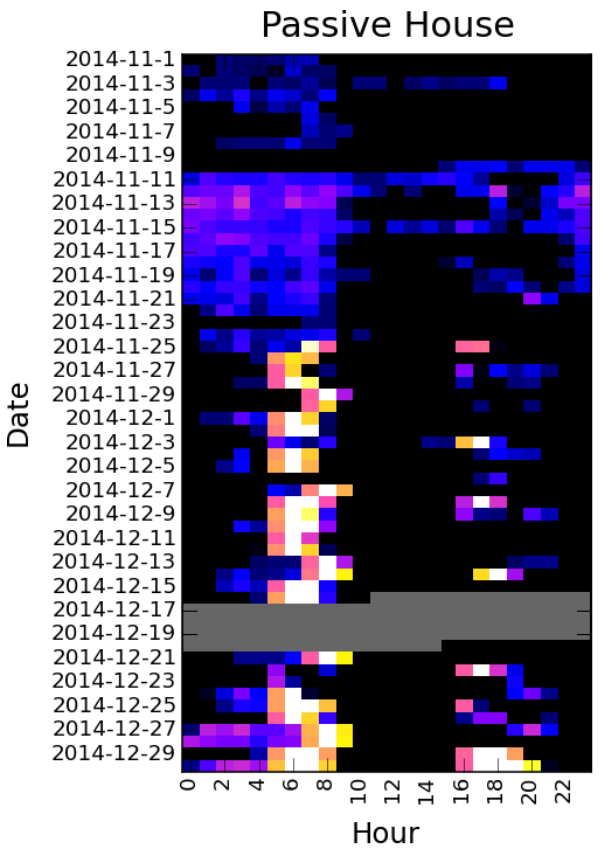

Control House 1

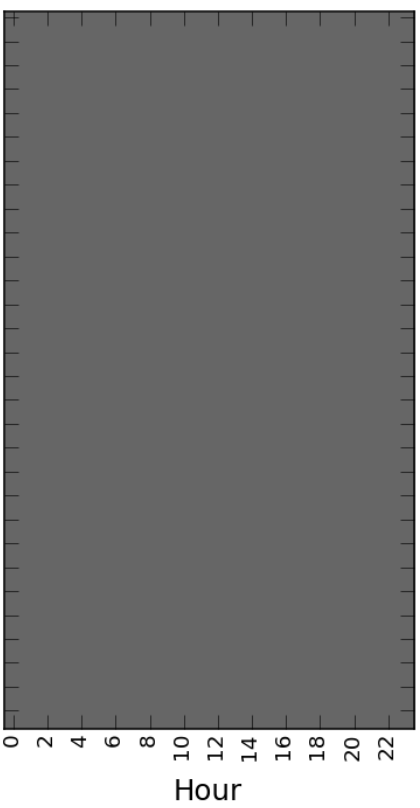

Control House 2

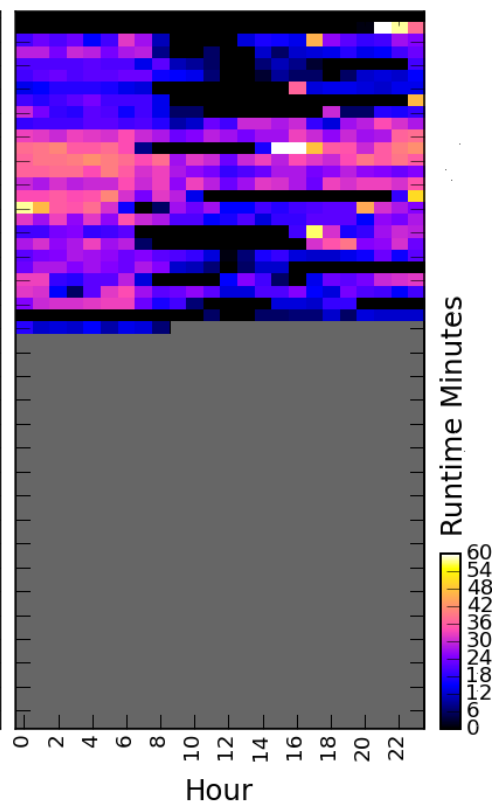

Figure 41. Heat map of system runtime-heating mode
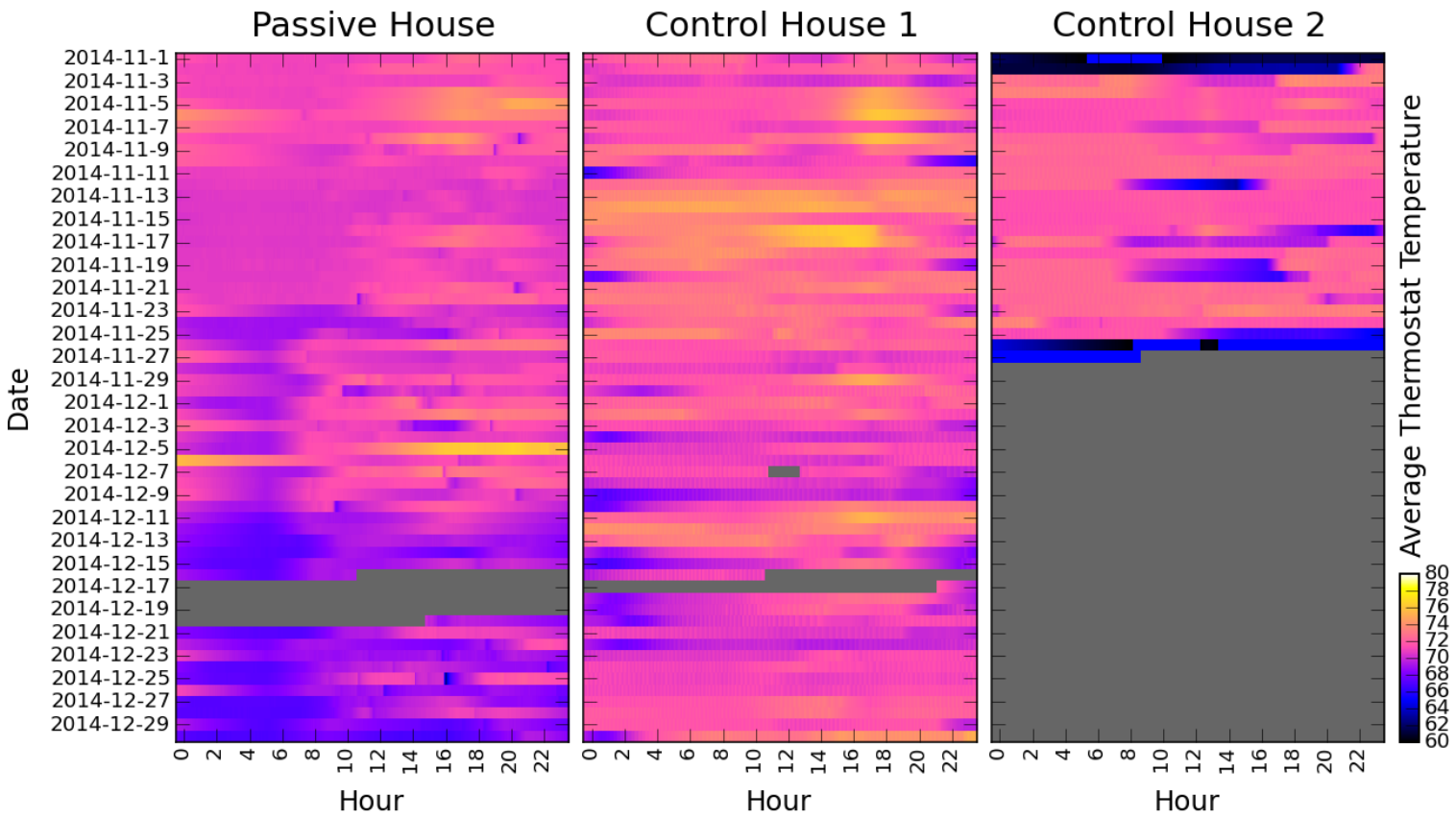

Figure 42. Heat map of thermostat temperature-heating mode

The team chose the master bedroom as a representative room to further consider potential deviations from the thermostat temperature. In each test house, this room was occupied and had western glazing. Figure 43 shows the temperature difference during cooling mode, and Figure 44 shows the temperature difference during heating mode. In these figures, small differences between the master bedroom and thermostat are shaded as a gradient. All values beyond $\pm 3^{\circ} \mathrm{F}$ 
during heating mode and $\pm 2^{\circ} \mathrm{F}$ during cooling mode are highlighted with fully saturated red and blue. The scale is not extended, so excursions are readily apparent.
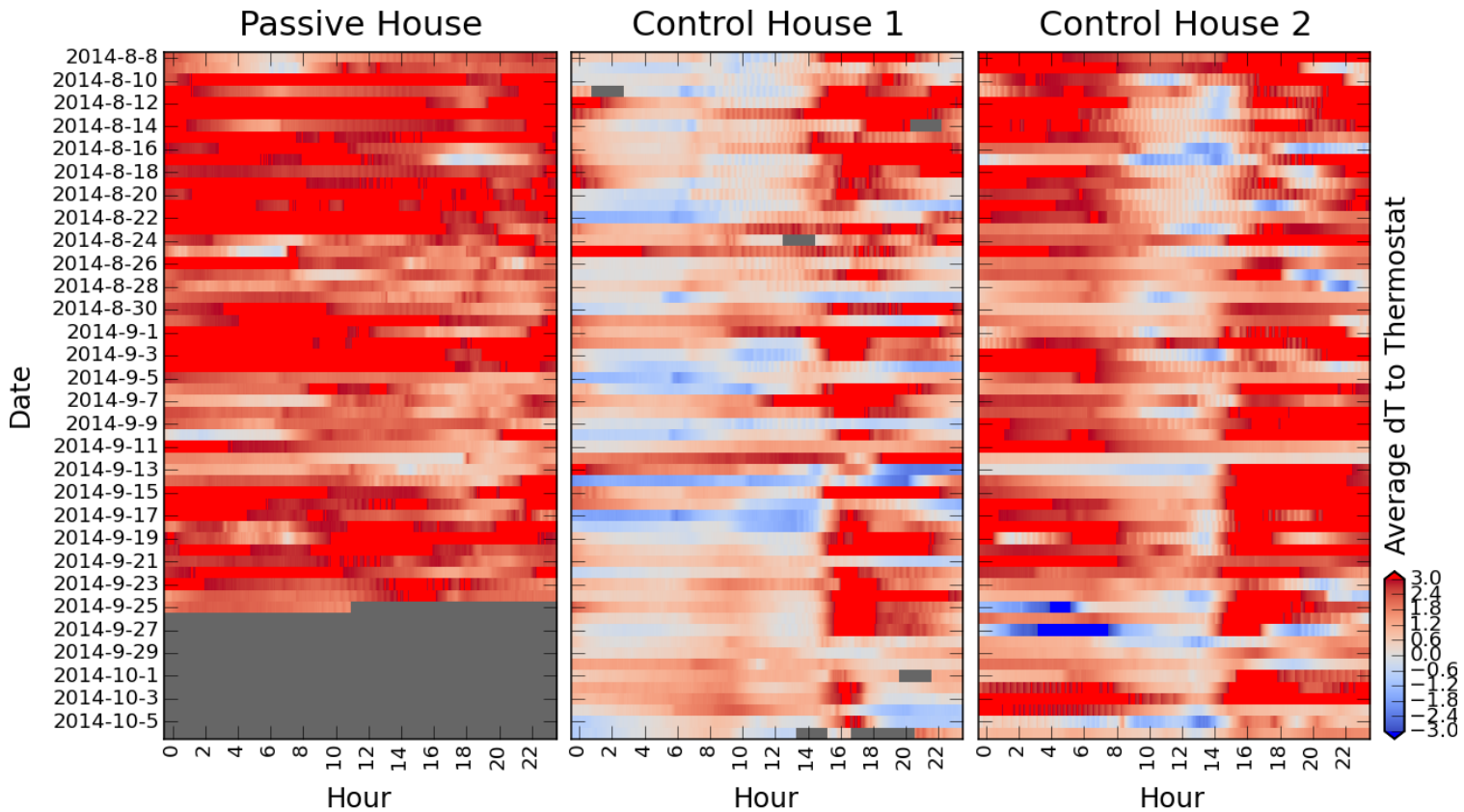

Figure 43. Temperature difference between the master bedroom and thermostat-cooling mode
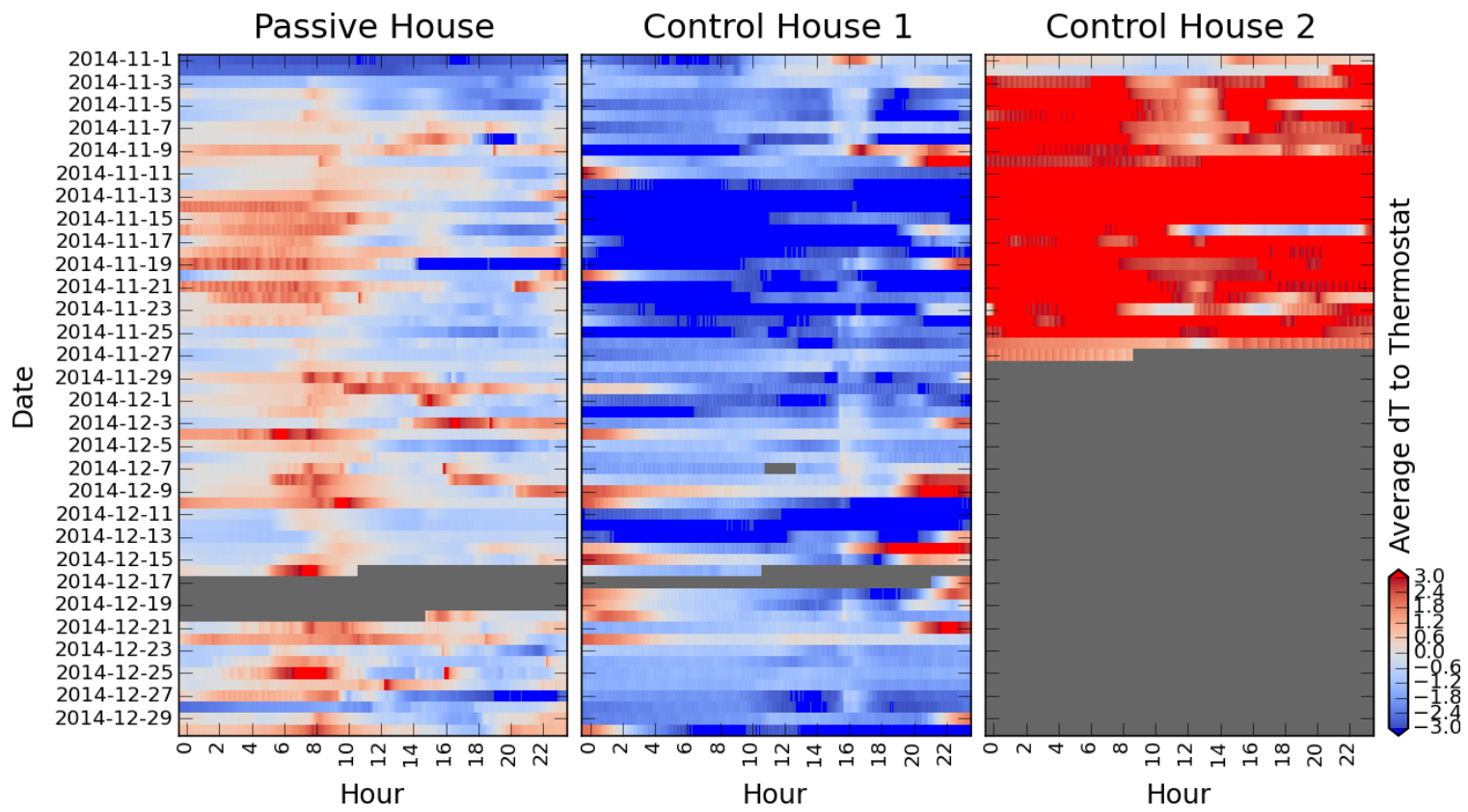

Figure 44. Temperature difference between the master bedroom and thermostat-heating mode

\subsection{Air Conditioning Contractors of America Manual RS}

Results in this section look at data from the Passive House only. Results from the ACCA analysis are presented to demonstrate room-to-thermostat temperature uniformity. Table 10 
summarizes the percentage of time each room deviated by more than $2^{\circ} \mathrm{F}$ during the heating season and $3^{\circ} \mathrm{F}$ during the cooling season for each representative day. For reference, the total system runtime for that day and the outdoor average temperature also are included. When the room was outside the comfort band for $0 \%$ of the time, the number was omitted for clarity.

Table 10. Percentage of Time a Room Was Outside ACCA Thermal Uniformity Guidelines (Passive House)

\begin{tabular}{|c|c|c|c|c|c|c|c|c|c|}
\hline & 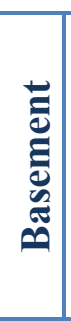 & 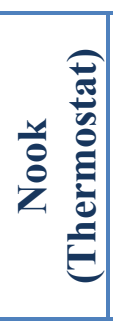 & 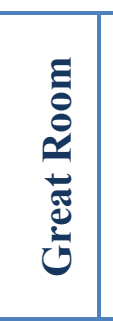 & 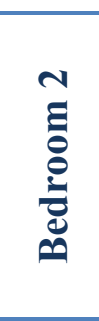 & 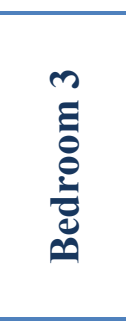 & $\overline{\bar{X}}$ & 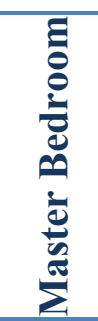 & 古 & 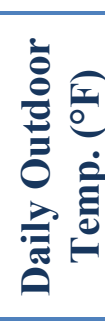 \\
\hline $9 / 3 / 2014$ & - & - & - & $7 \%$ & $59 \%$ & $5 \%$ & $91 \%$ & 430 & 78 \\
\hline $9 / 4 / 2014$ & - & - & - & - & $45 \%$ & $2 \%$ & $83 \%$ & 213 & 65 \\
\hline $11 / 12 / 2014$ & - & - & - & $80 \%$ & $90 \%$ & $99 \%$ & - & 382 & 3 \\
\hline $11 / 13 / 2014$ & - & - & $11 \%$ & $92 \%$ & $100 \%$ & $100 \%$ & - & 316 & 4 \\
\hline
\end{tabular}

Throughout the project, it became apparent that for the Passive House, when the system cycled on, the temperature in the rooms changed at a different rate than the temperature at the thermostat. During the operation of a perfectly balanced HVAC system, the temperature in each room should change at the same rate, as reflected by the slope of the $\Delta \mathrm{T}$ graph. As shown in Figure 45, several rooms heated at a much higher rate during long heating cycles than the rest of the house. Figure 45 shows both the room-to-thermostat temperature difference, as well as actual room temperatures. See Section 6.3 for a discussion about the data presented in this section.
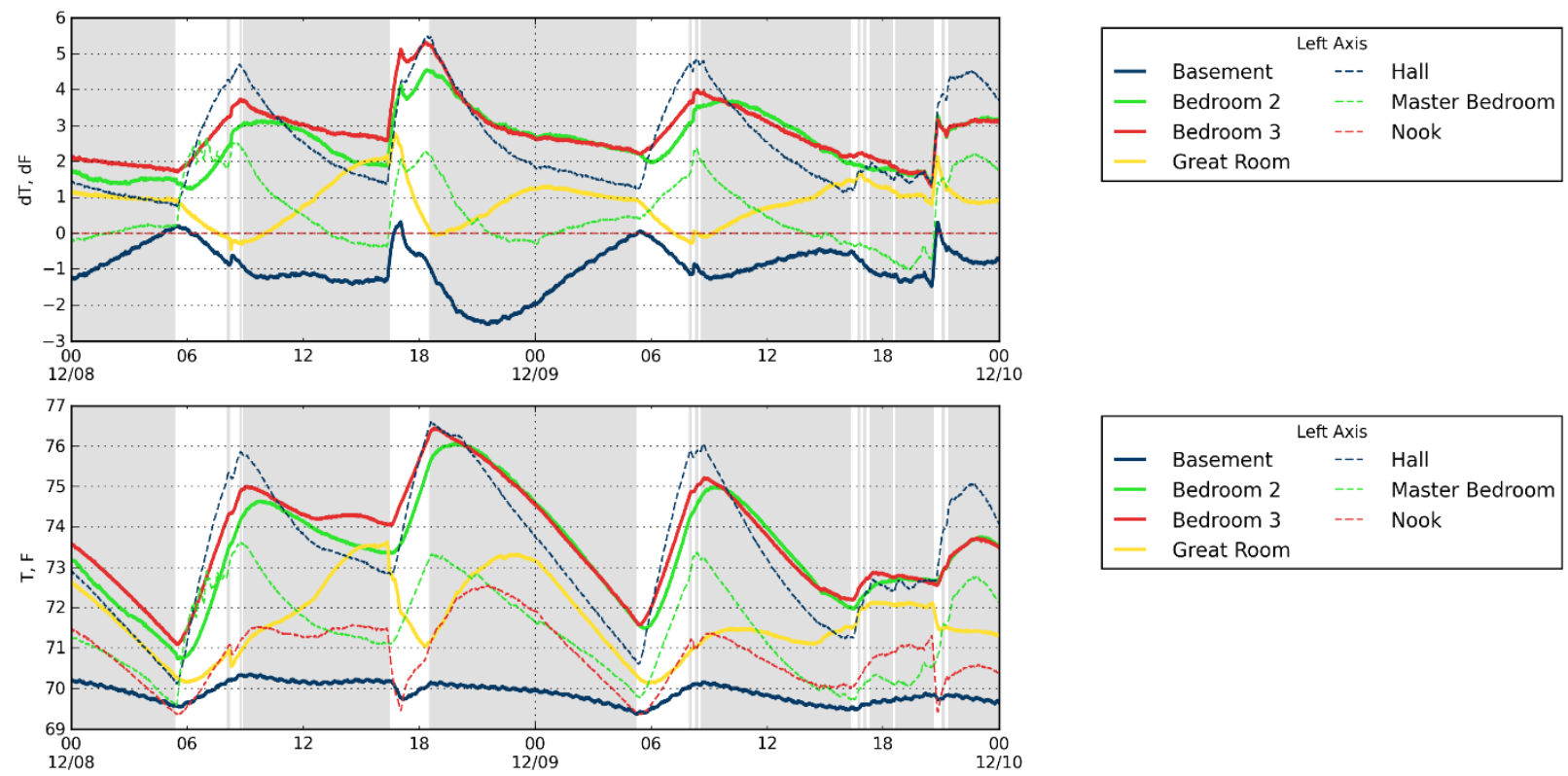

Figure 45. Passive House-room-to-thermostat temperature difference 


\subsection{ASHRAE Standard 55-2010 Cycles and Drifts}

The research team analyzed data from the entire analysis period (August 8, 2014 through February 22, 2015) for the Passive House in accordance with ASHRAE Standard 55 cycles and drifts metric (ASHRAE 2010). Discussion of the cycles and drifts standard is included in Section 7.1 .

The total number of occurrences of a particular zone failing the cyclic or drift standard is presented in Table 11. Values shown in the table represent the total number of unique periods in which a particular zone failed the cycle or drift standard. Only the rooms and periods in which the standard was not achieved are emphasized. Summer data were excluded because only three unique failures occurred. Several rooms were also excluded from the winter data because those rooms did not fail the standard's recommendations. Section 7 discusses the data presented in this section.

Table 11. Total Count of ASHRAE Standard 55-2010 Cycle or Drift Occurrences

\begin{tabular}{c|c|c|c|c|c|c|c|c|c|c|c|c|c|c|c|c|c|c|c|c}
\hline Room & \multicolumn{4}{|c|}{ Great Room } & \multicolumn{4}{c|}{ Hall } & \multicolumn{4}{c|}{ Master Bedroom } & \multicolumn{4}{|c|}{ Nook (Thermostat) } \\
\hline Period (h) & $1 / 4$ & $1 / 2$ & 1 & 2 & 4 & $1 / 4$ & $1 / 2$ & 1 & 2 & 4 & $1 / 4$ & $1 / 2$ & 1 & 2 & 4 & $1 / 4$ & $1 / 2$ & 1 & 2 & 4 \\
\hline Heating Failures & 2 & 2 & & & 4 & & & & 16 & 20 & 10 & 4 & 10 & 12 & 12 & 24 & 6 & 2 & 2 & 4 \\
\hline
\end{tabular}




\section{Discussion}

The discussion focuses first on the long-term monitoring results from the Passive House. Those results then are compared to the results from Control House 1 and Control House 2. Additional detail is provided for the Passive House with regard to the ACCA room-to-thermostat uniformity and ASHRAE Standard 55-2010 cycles and drifts (ASHRAE 2010). Discussion then is provided for the Passive House design process and the cost impacts as estimated by the builder. Finally, results from the companion ZERH effort are discussed.

\subsection{System Runtime and Temperature Uniformity}

Short-cycling of HVAC equipment is a concern for high-performance homes if the equipment has not been sized appropriately. Short cycling can reduce the efficiency of heating and cooling and the amount of humidity extracted from the air in cooling mode. During heating mode, all homes exhibited some degree of short-cycling; median runtimes ranged from 5 to 9 min, even though outdoor temperatures hovered slightly higher or lower than the design temperature. If the heating systems were sized ideally, they would run almost continuously during this period. Figure 38 shows that Control House 2 apparently had a setback with a long, 139-min cycle returning from an $8^{\circ} \mathrm{F}$ setback. In peak hours during the cooling season, each air handling unit ran $100 \%$ of the time during peak conditions, suggesting that the cooling capacity was not oversized.

During cooling mode, the Passive House showed a degree of stratification from the first floor to the second floor. One cause may have been the HVAC design, which had a single supply trunk running through the floor cavity between the first and second floors. Rooms on the first floor were supplied by ceiling registers; rooms on the second floor were supplied by floor registers. During cooling mode, cold air tended to fall and mix with the first-floor air and satisfied the cooling demand. Meanwhile, on the second floor, the cold air tended to pool on the floor; it did not mix with all the room air and may have cascaded down the staircase. An ideal HVAC system to mitigate stratification would have floor-mounted registers on the first floor and ceilingmounted registers on the second floor. Also, the thermostat was in a central location, shielded from rooms with solar heat gains. This location may have represented the most "neutral" spot in the house but may not have represented the majority of living spaces. According to the room-tothermostat uniformity metric, many of the rooms in this house appeared to be overheated; however, the rooms actually tracked each other quite closely. The occupant reported "amazing" comfort satisfaction in winter and stated that the top floor felt warm during summer. Because of the thermostat location, the ACCA Manual RS metric (Rutkowski 1997) may not be indicative of actual perceived comfort.

In addition to ductwork and thermostat placement, differences in heating and cooling load balance may have necessitated rebalancing airflows between seasons. However, the installed ductwork design did not provide access to supply branch ducts or a location to install a manual balancing damper. If the occupants could have seasonally rebalanced airflows, the comfort may have been improved in each season.

Control House 1 showed a distinct overheating pattern in heating and cooling modes because of solar heat gains. The fenestration in Control House 1 is primarily on the western façade. Also, 
Control House 1 was at the end of the block, with a large gap between it and the next house to the west. Control House 2 was located directly between two other houses that provided shade during the evening. The team does not know if the installed window shades were drawn during the days analyzed, but similar behavior was seen on many hot and sunny days. At hour 18, when the sun set below the horizon, a distinct change in behavior was noted in the room-to-thermostat temperature differences. Previously, when the sun was out, the rooms were moving away from the thermostat value and each other; once the sun set, the temperature difference between rooms stabilized.

Figure 34 shows that the master bedroom was the warmest room on September 3, 2014; however, the hall was the warmest area on September 4, 2014. The causes of this were likely the solar heat gains and the insufficient shading for the master bedroom. September 3, 2014 was a very sunny day, whereas September 4, 2014 was cloudy throughout the afternoon.

Each of the three houses showed at least one extended cycle longer than 90 min on September 3, 2014 , when the outdoor temperature was slightly higher than the $92^{\circ} \mathrm{F}$ design temperature. This indicates the cooling systems were not oversized for the loads. Several rooms in Control House 1 had evening peak temperatures because of western exposure and solar heat gains.

The master bedroom in the Passive House tended to be hot in the summer and cool in the winter. This room had significant exterior surface area, because it was located at one end of the house and above the unconditioned garage. Also, although airflow delivered to the zone exceeded the design level, the excess airflow to this zone was much lower than that to the other zones. More airflow may have reduced the departure of the room from the thermostat set point during cooling months.

A significant conclusion from this section is that proper airflow balancing is critical in providing uniform temperatures across each zone. Bringing ductwork into conditioned space and maintaining access to each duct branch at the plenum for an operable damper present challenges. Once ductwork has been brought into conditioned space, it often is sequestered behind drywall. Easy centralized access to each damper would allow for changing balance with the seasons or changing internal gains.

\subsection{Air Conditioning Contractors of America Room-to-Thermostat Temperature Uniformity-Passive House}

The ACCA Manual RS (Rutkowski 1997) thermal uniformity analysis showed several potential concerns and successes for the Passive House. Floor-to-floor stratification was apparent in the heating and cooling seasons. As discussed previously, placement of the HVAC registers may have contributed to this fact. Using high sidewall registers instead of floor- and ceiling-mounted registers may have provided more uniform comfort for cooling and heating. Registers were placed near the perimeter, which is not necessary for a house with a highly insulated envelope. The extra duct length could have been used instead to mount the registers on the inner walls.

Thermostat placement also should be considered when interpreting the results of this analysis. If the thermostat were less shielded from the externally driven temperature swings, it may have better represented the "average" house temperature. 
Installing an HVAC system with two zones, or perhaps using multiple ductless mini-split heat pump units, would be another strategy to help mitigate the floor-to-floor stratification.

The heat maps are a powerful way to quickly visualize trends in room temperature. During cooling mode, the master bedroom tended to overheat regularly in the evening, which makes sense with its western exposure. Control House 2 tended to overheat in the evening and morning. Several factors may have caused this. In the Passive House, during cooling mode, the master bedroom tended to always be warm because of insufficient airflow. The heat maps show somewhat irregular patterns in temperature deviation during heating mode, because the homes were designed to best accommodate heating.

The basement of the Passive House aligned more closely with the thermostat during the heating season than either of the other two control houses; it tended to range within $1^{\circ} \mathrm{F}$ of the thermostat. The basement in Control House 1 typically ranged from $4^{\circ} \mathrm{F}$ to $6^{\circ} \mathrm{F}$ below the thermostat. The basement in Control House 2 showed some temperature readings that were consistently higher than the thermostat value, which was unexpected. This might be explained by the large number of electronics associated with an in-home media server located in the basement.

\subsection{Cycles and Drifts-Passive House}

Through the cooling period of August 2014 through October 2014, the Passive House registered only a few cycle or drift failures. One failure occurred during a period when the HVAC system was not running and the house probably was unoccupied. The other two failures were likely caused by a window opening, because one room saw a sudden and distinct drop in air temperature. The occupants reported opening windows during warm weather.

Several regular cyclic and drift issues were apparent in the Passive House during the heating season (November 2014 through February 2015). The nook and master bedroom had regular 15min to 240-min failures when the temperature dropped rapidly. This is probably the result of an occupant opening a window and should not be considered as a true failure. The great room saw 1 day during which solar heat gains may have caused an excessive ramp in temperature. The most problematic zone was the second-floor hall, which saw a total of 20 ramp failures when the measured temperature rose by more than $6^{\circ} \mathrm{F}$ in a 4-h period because of a long HVAC runtime. This zone also had much higher than needed airflow and was directly at the top of the large open stairwell, which exacerbated the effect of floor-to-floor stratification. Because this zone was a hallway, it probably was not occupied for long and thus was not a concern for the occupants.

Ultimately, measured data in the Passive House indicated cycle or drift behavior that was insufficient to warrant concern. The temperatures in each room were sufficiently uniform over time so that they did not pose a comfort problem.

\subsection{Passive House Design and Construction Process Results}

The Passive House design process using the PHPP was an integrated effort between various design disciplines. Great value was found in the iterative design process; designers and the builder could see the impact of one decision on other aspects of the design. This instilled knowledge and understanding as the parties experienced the learning curve for Passive House design. The knowledge gained will provide insights if and when the builder chooses to pursue 
Passive House in production mode. The experience also will help the builder address design issues on its entire product line.

Many individual lessons were learned throughout the design and construction of this Passive House. Some specific lessons learned on the construction side mostly involved learning how to build with these new details. Bringing the contractors up to speed about these details included having the foreman show them first. This impacted the construction schedule and added cost to the project.

The extra cost that was incurred to build this Passive House was approximately $\$ 85,000$. The following is the best estimate of the cost breakdown as provided by the builder:

- Windows: $\$ 21,000$ (including installation)

- HVAC system: $\$ 28,000$ (including new design, system, and installation)

- Insulation: $\$ 11,000$

- Framing material, exterior insulation, and labor: $\$ 15,000$

- All other items combined: $\$ 10,000$.

The Passive House was sold in January 2014 for $\$ 529,000$. It originally was priced at $\$ 569,000$. If this house had been built with the same floor plan but without the Passive House upgrades, it would have been priced at approximately $\$ 469,000$.

The BEopt optimization curve developed with this project shows that the builder's standard practice was already fairly close to an optimized package. The builder could offer about $20 \%$ more energy savings for the same cost, or the builder could choose to reduce the cost and offer a $10 \%$ energy savings. Given how far from an optimum package the Passive House construction is, this type of construction is unlikely to be adopted by production homebuilders in the current market environment.

After construction, IBACOS reviewed the load calculations that were prepared by the mechanical contractor and found that the calculated load was excessive for the basement. The basement was modeled as if surrounded by outdoor air instead of being mostly below grade, which caused overestimated heat losses and gains. A $65^{\circ} \mathrm{F}$ temperature difference between the design interior conditions and the driving conditions was accounted for; this difference usually would be no more than $35^{\circ}$ for a below-grade space. This caused the basement load calculation to be overestimated by about $50 \%$. Table 12 shows the IBACOS calculation of the floor-by-floor loads. Differences here may help account for resulting comfort excursions. 
Table 12. Peak Heating and Cooling Loads, by Floor as Calculated by IBACOS

\begin{tabular}{c|c|c|c|c}
\hline & $\begin{array}{c}\text { Peak Heating } \\
\text { Load as } \\
\text { Determined by } \\
\text { IBACOS } \\
(\mathbf{B t u} / \mathbf{h})\end{array}$ & $\begin{array}{c}\text { Peak Heating } \\
\text { Load as } \\
\text { Determined by } \\
\text { Contractor } \\
\text { (Btu/h) }\end{array}$ & $\begin{array}{c}\text { Peak Cooling } \\
\text { Load as } \\
\text { Determined by } \\
\text { IBACOS } \\
(\mathbf{B t u} / \mathbf{h})\end{array}$ & $\begin{array}{c}\text { Peak Cooling } \\
\text { Load as } \\
\text { Determined by } \\
\text { Contractor } \\
\text { (Btu/h) }\end{array}$ \\
\hline Basement & 2,285 & 5,611 & 1,209 & 966 \\
First Floor & 6,357 & 5,356 & 7,255 & 4,786 \\
Second Floor & 6,226 & 6,183 & 5,897 & 7,519 \\
Total & 14,868 & 17,150 & 14,361 & 13,271 \\
\hline
\end{tabular}

Refer to Appendix C for the contractor's ACCA Manual J and Manual D calculations (Rutkowski 2006 and 2009, respectively). Refer to Appendix E for the IBACOS ACCA Manual J (Rutkowski 2006) calculations performed using the Wrightsoft software package (Wrightsoft 2013).

\subsection{Zero Energy Ready Home Design Results}

As part of the companion effort, IBACOS reviewed the standard upgrades with the builder and the possibility of moving forward with ZERH requirements in the Brighton Heights area. Most of these requirements seemed doable for the builder except for the indoor air quality and renewable ready requirements; the roughing in for the future solar thermal presents a major challenge and concern.

IBACOS and the builder reviewed the mandatory requirements for ZERH compliance to identify technical challenges that needed to be resolved before any homes can be constructed to comply with ZERH. The initial review of these requirements identified potential challenges with the water efficiency and indoor air quality requirements. To address requirements for the hot water delivery system, the builder consulted with its plumbing partner to identify solutions for minimizing wasted water. The builder also consulted with IBACOS, its local HERS Rater, its HVAC partner, and Environmental Protection Agency Indoor airPLUS staff to identify the most cost-effective products and techniques for complying with the ZERH indoor air quality requirements.

The concern surrounding the indoor air quality requirement was related to the builder's feeling that the ZERH indoor air quality requirements unreasonably constrain the homeowner's choice of interior materials. At this time, the builder has chosen not to move forward with the ZERH design. No final design package resulted from this effort. 


\section{Conclusions}

The research questions presented previously are addressed in this section. The team has also found valuable conclusions in other areas. The six research questions follow:

1. How does the annual space-heating and space-cooling system runtime in the Passive House compare to a house that has Brookfield's standard energy-efficiency package?

Runtime patterns differed between the heating and cooling data analyzed. All houses showed a degree of short-cycling during heating mode. During the 2-day period of analysis, the furnace ran 697 min in the Passive House, 970 min in Control House 1, and 1,184 min in Control House 2. Short-cycling was the most prevalent in Control House 1, which had a median furnace runtime of $5 \mathrm{~min}$, even though the outdoor temperature hovered lower than the $7^{\circ} \mathrm{F}$ design temperature. Ultimately, although the Passive House showed less frequent operation compared to the builder's standard, all furnaces could be downsized to improve comfort and efficiency.

Cooling season data indicate that the air conditioner's capacity was not oversized for any of the three houses. On a day when the high temperature was higher than the design temperature, the air conditioner ran for $100 \%$ of at least 1 peak hour. The total 2-day runtime of the air conditioner in the Passive House was 693 min; Control House 1 showed 888 min of operation, and Control House 2 showed 711 min of operation.

Although it was outside the scope of the project, the research team observed that for the Passive House the balance point temperature was near $50^{\circ} \mathrm{F}$, whereas the balance point temperature for the two control houses was near $55^{\circ} \mathrm{F}$. Denver's sunny climate likely contributed to this shift in balance points. However, the observed trend is that as thermal envelopes improve and homeowners purchase more heat-emitting electronics, balance point temperatures in the range of $50^{\circ} \mathrm{F}$ to $60^{\circ} \mathrm{F}$ will become more common. As such, cooling will become the dominant comfort concern in many climates previously thought of as heating dominated. With a balance point of $50^{\circ} \mathrm{F}$, Denver's climate produces a nearly even split of cooling and heating degree days.

The runtime data indicate a need for smaller-capacity gas furnaces and variable-capacity furnaces to better accommodate shrinking heating loads. Furnaces that have lower supply air temperatures also may help to reduce floor-to-floor thermal stratification.

2. How do the room-to-room and room-to-thermostat temperature offsets in the Passive House compare to a house that has Brookfield's standard energy-efficiency package?

Calculations comparing the daily average maximum room-to-room temperature difference showed that the Passive House maintained a more uniform temperature than the two control houses. During 2 cooling season days, the Passive House had an average maximum room-toroom temperature difference of $5.1^{\circ} \mathrm{F}$, whereas the temperature difference in the control houses ranged from $7.3^{\circ} \mathrm{F}$ to $8.3^{\circ} \mathrm{F}$. Data collected from the heating season showed similar results. During 2 representative heating days, on average each room of the Passive House was within $3.7^{\circ} \mathrm{F}$, and each room of the two control houses ranged from $5.9^{\circ} \mathrm{F}$ to $8.2^{\circ} \mathrm{F}$. 
3. Was the installed space-conditioning system appropriate to use in a cold-climate Passive House that will maintain occupant comfort to ACCA Manual RS (Rutkowski 1997) and ASHRAE Standard 55-2010 (ASHRAE 2010) guidelines?

The measured results indicate that the installed system had several shortcomings. The first and most apparent observation is that the thermostat was placed in a location that was not representative of the average house temperature. Passive House design results in thermal zones that are more susceptible to the impacts of solar heat gains and less susceptible to conductive loss through the enclosure. By placing the thermostat in a space that was isolated from the solar heat gains, the rest of the house tended to be warmer than the temperature at the thermostat. Ultimately, the house appeared to fail the room-to-thermostat uniformity standard, even though the occupants expressed delight about the heating comfort. If the thermostat were placed in a more representative zone, the house probably would have continued to maintain similar acceptable temperatures and would have shown significantly fewer thermal abnormalities. Cooling season excursions also could have been improved if the thermostat were in a zone that experienced at least some solar heat gains.

Floor-to-floor stratification was prevalent during the summer; the master bedroom showed the greatest temperature differential. Duct design likely contributed to the stratification. Ductwork was located in the floor cavity between the first and second floors. Registers were ceiling mounted on the first floor and floor mounted on the second floor. During heating mode, this geometry tended to favor the second floor with conditioned air; during cooling mode, it favored the first floor. Both factors tended to increase floor-to-floor stratification. An ideal duct design would have used floor registers on the first floor and ceiling registers on the second floor but at the cost of significantly longer duct runs. A compromise would have been to locate high-sidewall registers on the interior walls in both cases.

When measured data were compared to the ASHRAE guidelines for cycles and drifts, few failures were observed. Many of the observed failures appear to be the result of window and door operation. The only systematic failure of the house and HVAC system was measured on the second-floor hall. This zone tended to ramp at a much higher rate than the rest of the house in heating mode because of its location at the top of an open stairway and near the second-floor return plenum. Furthermore, this zone is not consistently occupied and was unlikely to cause a comfort problem for the occupants.

4. How does the actual space-heating and space-cooling energy use compare to BEopt Version 2.1.0.1 (NREL 2013) or other energy simulations when actual weather conditions are normalized?

The research team used BEopt to model the performance of the Passive House with the actual weather, building characteristics, and measured air leakage normalized. Under these assumptions and with the standard thermostat set points and schedules, the model seemed to significantly overestimate the heating load based on approximated data. On the other hand, cooling results better matched the load; minor differences in diurnal variations were likely due to occupant behavior. Thermostat set point values and schedules were varied but did not yield significantly better correlation with the measured data when modulated within reasonable bounds. The probable cause of the difference in heating load is underestimated internal gains. To adequately 
diagnose differences between the modeled and measured data, a significant model calibration effort would be needed, which is outside the scope of this project.

5. What are the costs associated with production construction methods to achieve ZERH levels of energy performance?

Because the builder is choosing not to proceed with ZERH production at this time, no additional data are available to answer this research question.

6. How does the adoption of ZERH impact a builder's business planning?

IBACOS proposed options for Brookfield to bring its product in line with ZERH standards. Brookfield reviewed these ideas internally but did not move forward with further discussion with IBACOS and has not yet implemented ZERH standards in any of its homes. At this time, the builder did not view ZERH as a priority compared to other business concerns. This research question thus cannot be answered.

Additional conclusions can be drawn, however, relative to the costs of a Passive House. For a base plan that typically would be set at a selling price of $\$ 469,000$, the builder-estimated additional construction cost to build the Passive House is $\$ 85,000$, or $18.1 \%$ of the base price. The Passive House was listed at $\$ 569,000$, but it sold for $\$ 529,000$, which did not cover the builder's investment. The cost-optimization process shows that building to Passive House standards is a costly venture - one that is far removed from an optimized point from mortgaged first-cost and energy-cost standpoints.

The data presented in this report are from a production homebuilder's first experience with Passive House construction; all parties involved experienced a learning curve. Costs would presumably be reduced once the production mode is implemented. This is a point of reference for other builders because each builder that incorporates Passive House into its product offering will experience an initial learning curve.

Given how far the Passive House construction is from an optimum package, based on the BEopt analysis this type of construction is unlikely to be adopted by production homebuilders in the current market environment.

Another conclusion from this project involves ways to analyze comfort conditions in a home. In this project, the researchers found that heat maps are a powerful way to quickly visualize trends in room temperature to assess comfort in the house.

Researchers must critically examine their methods for representing data and analysis. In the homebuilding industry, builders also can benefit from clear graphic representations that can help them understand, for example, occupant comfort and can help homebuyers understand why comfort is worth buying. For most people, imagery resonates better than numbers and illustrates the inherent meaning of data. The heat map is a simple but powerful visual representation of temperature data in service to a comfort analysis.

A heat map plot provides an intuitive reading of the analysis through the use of color to indicate problem areas. The grid cells categorically and sequentially organize the data, and the depth coded by color represents the measurements, with an upper bound marking the failures. Heat maps show promise in the future of comfort research. 


\section{References}

ASHRAE. 2010. ANSI/ASHRAE Standard 55-2010, Thermal Environmental Conditions for Human Occupancy. Atlanta, GA: ASHRAE.

ASHRAE. 2013. ANSI/ASHRAE Standard 62.2-2013. Ventilation and Acceptable Indoor Air Quality in Low-Rise Residential Buildings. Atlanta, GA: ASHRAE.

DOE. 2014. DOE Zero Energy Ready Home National Program Requirements (Rev. 04). Washington, D.C.: U.S. Department of Energy, www.energy.gov/sites/prod/files/2014/04/f15/doe zero energy ready home requirements_rev0 4.pdf.

NREL. 2013. Building Energy Optimization with Hour-by-Hour Simulations, Version 2.1.0.1. Golden, CO: National Renewable Energy Laboratory. http://beopt.nrel.gov/.

Passive House. 2012. Passive House Planning Package modeling software. Darmstadt, Germany: Passive House Institute. Accessed October 15, 2015: www.passiv.de/en/04 phpp/04 phpp.htm.

Poerschke, A., and R. Beach. 2015. Comfort in High-Performance Homes in a Hot-Humid Climate (Subcontract Report, NREL/SR-5500-64994). Golden, CO: National Renewable Energy Laboratory (in publication).

Rutkowski, H. 1997. Manual RS-Comfort, Air Quality, and Efficiency by Design. Arlington, VA: Air Conditioning Contractors of America. www.acca.org/technical-manual/manual-rs/.

Rutkowski, H. 2006. Manual J-Residential Load Calculation, 8th edition, Version 2. Arlington, VA: Air Conditioning Contractors of America. www.acca.org/technical-manual/manual-j/.

Rutkowski, H. 2009. Manual D—Residential Duct Systems, 3rd edition, Version 1.00. Arlington, VA: Air Conditioning Contractors of America. www.acca.org/technical-manual/manual-d/.

Wrightsoft. 2013. Right-Suite ${ }^{\mathrm{TM}}$ Universal, Version 8.0.11 RSU00593. Lexington, MA: Wrightsoft Corporation. 


\section{Appendix A: Standard Package versus Passive House Package}

Table 13 compares the specifications of the builder's standard package with those of the Passive House package.

Table 13. Specifications for the Builder's Standard Product and the Passive House

\begin{tabular}{|c|c|c|}
\hline Specifications & Standard Package & Passive House Package \\
\hline Slab R-Value & 0 & $\begin{array}{l}4 \text { in. of extruded polystyrene foam (R-20) } \\
\text { under-slab/slab edge }\end{array}$ \\
\hline Slab Insulation & NA & Extruded polystyrene \\
\hline Foundation Wall R-Value & $\begin{array}{c}\text { R-19, GI (below grade); } \\
\text { R-26, GI (above grade/floor cavity) }\end{array}$ & $\mathrm{R}-10+\mathrm{R}-35$ \\
\hline Foundation Wall Insulation & $\begin{array}{l}\text { Draped (below grade); ccSPF and fiberglass batt } \\
\text { (above grade/floor cavity) }\end{array}$ & $\begin{array}{l}\text { R-10 foam and } 10 \text { in. of blown fiberglass } \\
\text { cavity insulation, } \\
2 \times 4 \text { stud wall at } 24 \text { in. on center }\end{array}$ \\
\hline Wall Cavity R-Value & R-27, GI & R-11 + R-30 GI \\
\hline Wall Cavity Insulation Type(s) & $\begin{array}{l}2 \text { in. of ccSPF plus } \\
3-1 / 2 \text { in. of cellulose }\end{array}$ & $\begin{array}{l}2 \text { in. of ccSPF with } \\
9 \text { in. of cellulose in a staggered double stud } \\
\text { wall system, } 24 \text { in. on center }\end{array}$ \\
\hline $\begin{array}{c}\text { Wall Sheathing R-Value (if } \\
\text { applicable) }\end{array}$ & N/A & $\mathrm{N} / \mathrm{A}$ \\
\hline Knee Wall R-Value & $\begin{array}{l}\text { R-15 with } 2 \times 4 \text { framing GI, or } \\
\text { R-20 with } 2 \times 6 \text { framing GI }\end{array}$ & N/A \\
\hline $\begin{array}{c}\text { Knee Wall Cavity Insulation } \\
\text { Type(s) }\end{array}$ & 2 in. of ccSPF plus $3-1 / 2$ in. of cellulose & N/A \\
\hline $\begin{array}{c}\text { Knee Wall Framing Type and } \\
\text { Spacing }\end{array}$ & $\begin{array}{c}2 \times 4 \text { or } 2 \times 6 \text { with a } 2 \times 6 \text { and } \\
2 \times 4 \text { at the garage wall when mechanicals are } \\
\text { required in the wall }\end{array}$ & N/A \\
\hline Rim/Band/Box Sill R-Value & R-27, GI & $\mathrm{R}-11+\mathrm{R}-30 \mathrm{GI}$ \\
\hline
\end{tabular}




\begin{tabular}{|c|c|c|}
\hline Specifications & Standard Package & Passive House Package \\
\hline $\begin{array}{c}\text { Rim/Band/Box Sill Insulation } \\
\text { Type(s) }\end{array}$ & 2 in. of ccSPF plus R-13 batt & 2 in. of ccSPF with 9 in. of cellulose \\
\hline Ceiling/Attic R-Value & R-50 (R-38 at the eaves), GI & $\mathrm{R}-60$ \\
\hline Ceiling/Attic Insulation Type(s) & Blown cellulose & ccSPF and blown cellulose \\
\hline $\begin{array}{c}\text { Ceiling/Attic Framing Type and } \\
\text { Spacing }\end{array}$ & $\begin{array}{c}2 \times 6 \text { or } 2 \times 4 \text { truss }(\text { mostly } 2 \times 4) \\
24 \text { in. on center }\end{array}$ & $2 \times 6$ or $2 \times 4$ truss $($ mostly $2 \times 4)$ \\
\hline Raised Heel Trusses (Yes/No) & Yes (estimated 11-12 in.) & $\begin{array}{l}\text { Yes (estimated } 18-22 \text { in.) spray foam at the } \\
\text { eaves to maintain R- } 84\end{array}$ \\
\hline Floor R-Value & $\begin{array}{l}\text { R-48 blown fiberglass at the first floor over } \\
\text { unconditioned space; R- } 60 \text { at the second floor } \\
\text { over unconditioned space }\end{array}$ & R-60 second floor over unconditioned space \\
\hline $\begin{array}{c}\text { Floor Framing Type and } \\
\text { Spacing }\end{array}$ & $\begin{array}{l}\text { First floor: } 24 \text { in. on center Trus Joist I } 210 \text { (11- } \\
7 / 8 \text { in. high). Second floor: } 24 \text { in. on center open } \\
\text { web truss (14 in. high) }\end{array}$ & $\begin{array}{l}\text { Second floor: } 24 \text { in. on center open web truss } \\
\qquad(14 \mathrm{in} . \text { high })\end{array}$ \\
\hline $\begin{array}{l}\text { Window U-Value } \\
\text { (Low-E Windows) }\end{array}$ & 0.3 & 0.14 \\
\hline $\begin{array}{c}\text { Window Solar Heat Gain } \\
\text { Coefficient (Low-E Windows) }\end{array}$ & 0.3 & 0.5 \\
\hline Door U-Value & $>0.167$ & 0.30 (glazed); 0.14 (solid) \\
\hline Duct Location & Basement, chases, and midfloor & Inside conditioned space \\
\hline Duct R-Value & Uninsulated sheet metal & Uninsulated sheet metal \\
\hline $\begin{array}{l}\text { Average Total Duct Leakage } \\
\text { (CFM25 per } 100 \mathrm{ft}^{2} \text { conditioned } \\
\text { floor area) }\end{array}$ & $\leq 6 \mathrm{CFM}$ per $100 \mathrm{ft}^{2}$ conditioned floor area & $\leq 8 \mathrm{CFM}$ per $100 \mathrm{ft}^{2}$ conditioned floor area \\
\hline Heating & Natural gas furnace 93 AFUE Lennox & $\begin{array}{l}\text { First Company fan coil unit with hot water coil } \\
\text { with heat supplied from the Navien } \\
\text { Condensing Combi unit } \sim 0.93 \text { AFUE }\end{array}$ \\
\hline Air Conditioning & $\begin{array}{l}13 \text { seasonal energy efficiency ratio air } \\
\text { conditioner (Lennox XC13) optional }\end{array}$ & $\begin{array}{c}\text { Lennox XC21,21 seasonal energy efficiency } \\
\text { ratio air conditioner }\end{array}$ \\
\hline HVAC Equipment Location & Basement & Second-floor closet \\
\hline $\begin{array}{c}\text { Programmable Thermostat } \\
\text { (Yes/No) }\end{array}$ & Yes & Yes \\
\hline
\end{tabular}




\begin{tabular}{|c|c|c|}
\hline Specifications & Standard Package & Passive House Package \\
\hline $\begin{array}{c}\text { Whole-House Ventilation } \\
\text { Strategy }\end{array}$ & $\begin{array}{c}\text { Exhaust only at laundry room } \\
\text { ( } 3 \text { bedrooms at } 3,200 \mathrm{ft}^{2}=62 \mathrm{CFM} \text { ) }\end{array}$ & $\begin{array}{l}\text { Zehnder ComfoAir } 350 \mathrm{ERV}, 91 \% \text { efficient, } \\
\text { electric power consumption }=0.31 \mathrm{~W} / \mathrm{m}^{3}\end{array}$ \\
\hline Water Heater Type(s) & Tankless gas & Tankless gas \\
\hline Water Heater Energy Factor & 0.96 (gas) & 0.96 (gas) \\
\hline Water Heater Location & Basement & Second-floor closet \\
\hline Desuperheater Used (Yes/No) & No & No \\
\hline$\%$ Energy Efficient Lighting & $\begin{array}{c}100 \% \text { compact fluorescent lamps interior, } \\
\text { exterior, and garage }\end{array}$ & $\begin{array}{l}100 \% \text { compact fluorescent lamps and light- } \\
\text { emitting diodes interior, exterior, and garage }\end{array}$ \\
\hline Dishwasher Energy Factor & 0.60 energy factor & 0.60 energy factor \\
\hline Refrigerator Usage & $691 \mathrm{kWh} / \mathrm{yr}$ optional & $691 \mathrm{kWh} / \mathrm{yr}$ \\
\hline Dryer Specifications & 3.01 efficiency optional & 3.01 efficiency \\
\hline Clothes Washer Presets & Residential Energy Services Network & Residential Energy Services Network \\
\hline $\begin{array}{l}\text { Type of Pipes (Copper, cross- } \\
\text { linked polyethylene, chlorinated } \\
\text { polyvinyl chloride, etc.) }\end{array}$ & Upenor cross-linked polyethylene & Upenor cross-linked polyethylene \\
\hline $\begin{array}{l}\text { Type of Plumbing System } \\
\text { (Branch and T, Home Run) }\end{array}$ & $\begin{array}{l}\text { Branch and T (cold); } \\
\text { structured recirculation design (hot) }\end{array}$ & $\begin{array}{c}\text { Home run (Environmental Protection Agency } \\
\text { WaterSense compliant) }\end{array}$ \\
\hline Location of Plumbing Pipes & Basement and interior walls & Inside conditioned space \\
\hline Photovoltaic System & $\begin{array}{l}1.25 \mathrm{~kW} ; 165 \mathrm{ft}^{2} \text { collector area (DOW } \\
\text { Powerhouse solar shingles); } 18.4^{\circ} \text { tilt; } 180^{\circ} \\
\text { azimuth; } 94 \% \text { efficient inverter (DOW model } \\
\text { 362590), varies per site }\end{array}$ & $\begin{array}{l}1.2 \mathrm{~kW} ; 165 \mathrm{ft}^{2} \text { collector area } \\
\text { (DOW Powerhouse solar shingles); } 18.4^{\circ} \text { tilt; } \\
180^{\circ} \text { azimuth; } 94 \% \text { efficient inverter } \\
\text { (DOW model 362590) }\end{array}$ \\
\hline
\end{tabular}


Appendix B: Full Drawing Set of the Passive House 


\section{MIDTOWN \\ PLAN SA2508}

RESIDENCE EIGHT

68th Avenue $\&$ Pecos Street

UNICORPORATED ADAMS COUNTY, COLORADO

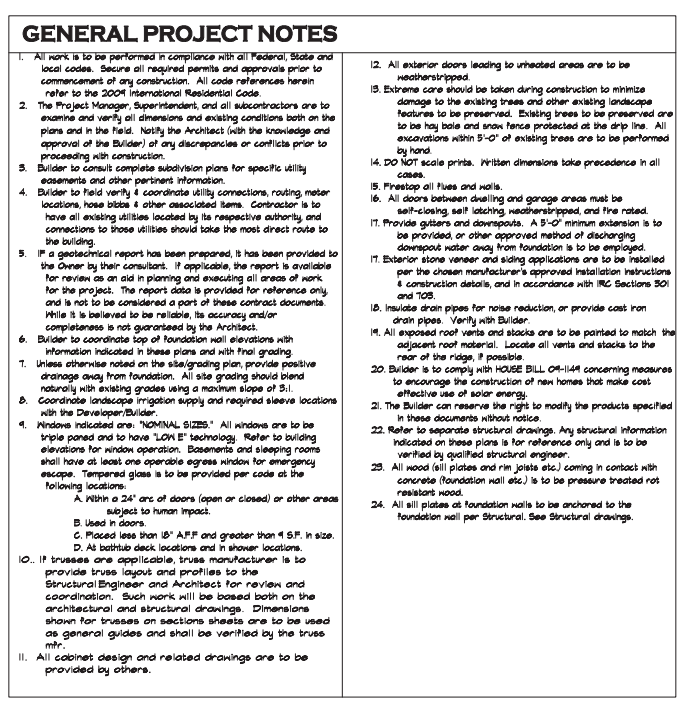

\begin{tabular}{|c|c|}
\hline \multicolumn{2}{|l|}{ PROJECT TEAM } \\
\hline OWNER/BUILDER: & $\begin{array}{l}\text { BROOKFIELD RESIDENTIAL (COLORADO) LLC. } \\
188 \text { INVERNESS DRIVE WEST, SUITE } 150 \\
\text { ENGLEWOOD, CO } 80112 \\
303-7906602 \\
\text { CONTACT: SHANNON ROBBINS }\end{array}$ \\
\hline ARCHITECT: & $\begin{array}{l}\text { KGA STUDIO ARCHITECTS } \\
\text { 950 SPRUCE STREET } \\
\text { LOUISVILLE, CO } 80027 \\
\text { 303-442-5882 } \\
\text { CONTACT: JOHN GUILLIAMS / GRAHAM SWETT }\end{array}$ \\
\hline ENERGY CONSULTANTS: & $\begin{array}{l}\text { IBACOS } \\
2214 \text { LIBERTY AVENUE } \\
\text { PITTSBURGH, PA } 15222 \\
412-605-4827 \\
\text { CONTACT: ANASTASIA HERK }\end{array}$ \\
\hline STRUCTURAL ENGINEER: & $\begin{array}{l}\text { GREEN CITY CONSULTING } \\
\text { 3801 E. FLORIDA AVENUE } \\
\text { DENVER, CO } 80201 \\
\text { 303-758-8880 } \\
\text { CONTACT: RON NGANTUNG }\end{array}$ \\
\hline GEOTECHNICAL ENGINEER: & $\begin{array}{l}\text { A.G. WASSENAAR, INC. } \\
2180 \text { S IVANHAE } \\
\text { DENVER, CO } 80222 \\
303-759.8100 \\
\text { CONTACT: MIKE CONNOR }\end{array}$ \\
\hline
\end{tabular}

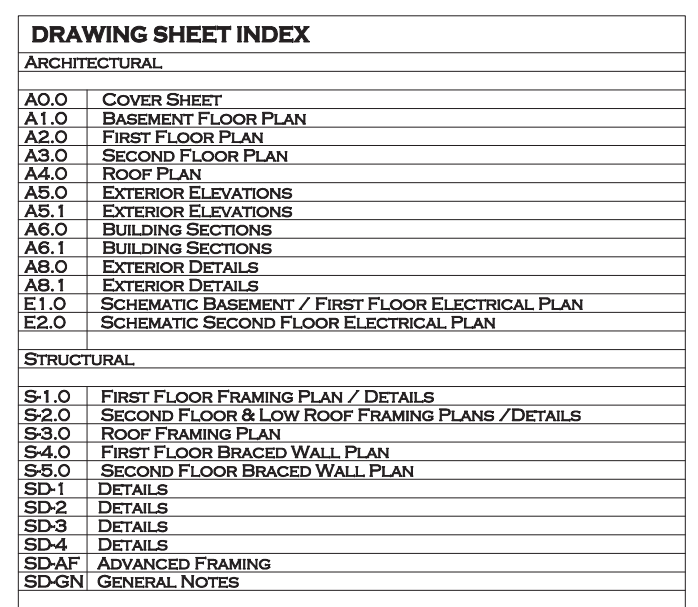

PROJECT DATA
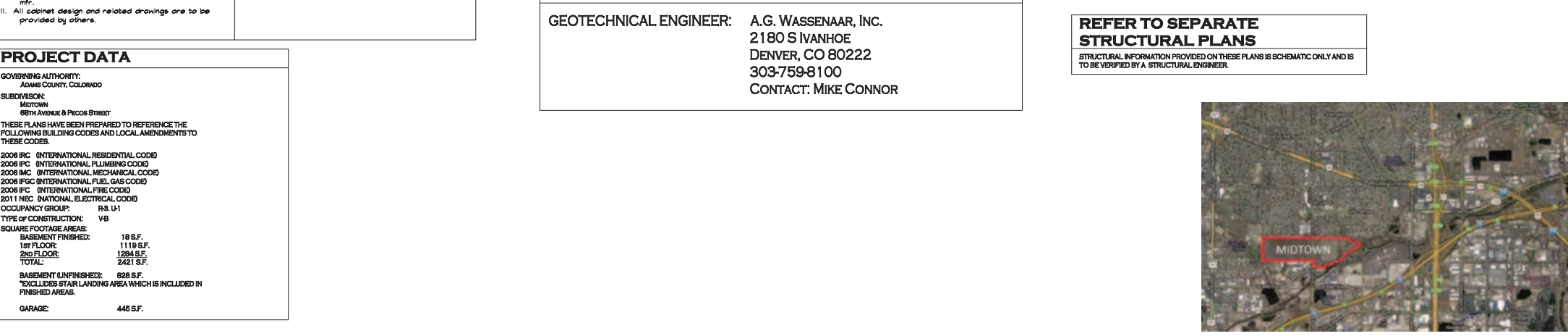

VICINITY MAP

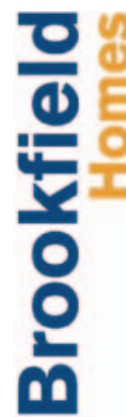

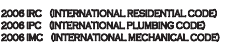

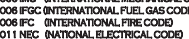

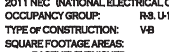

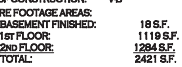

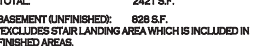
$445 s$.

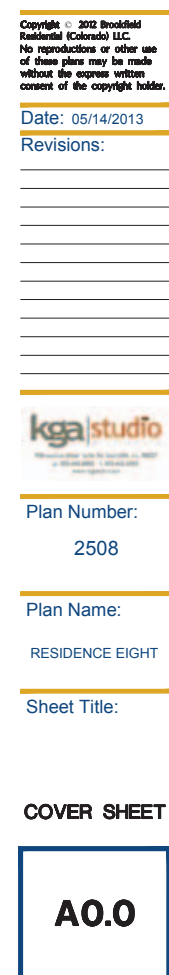




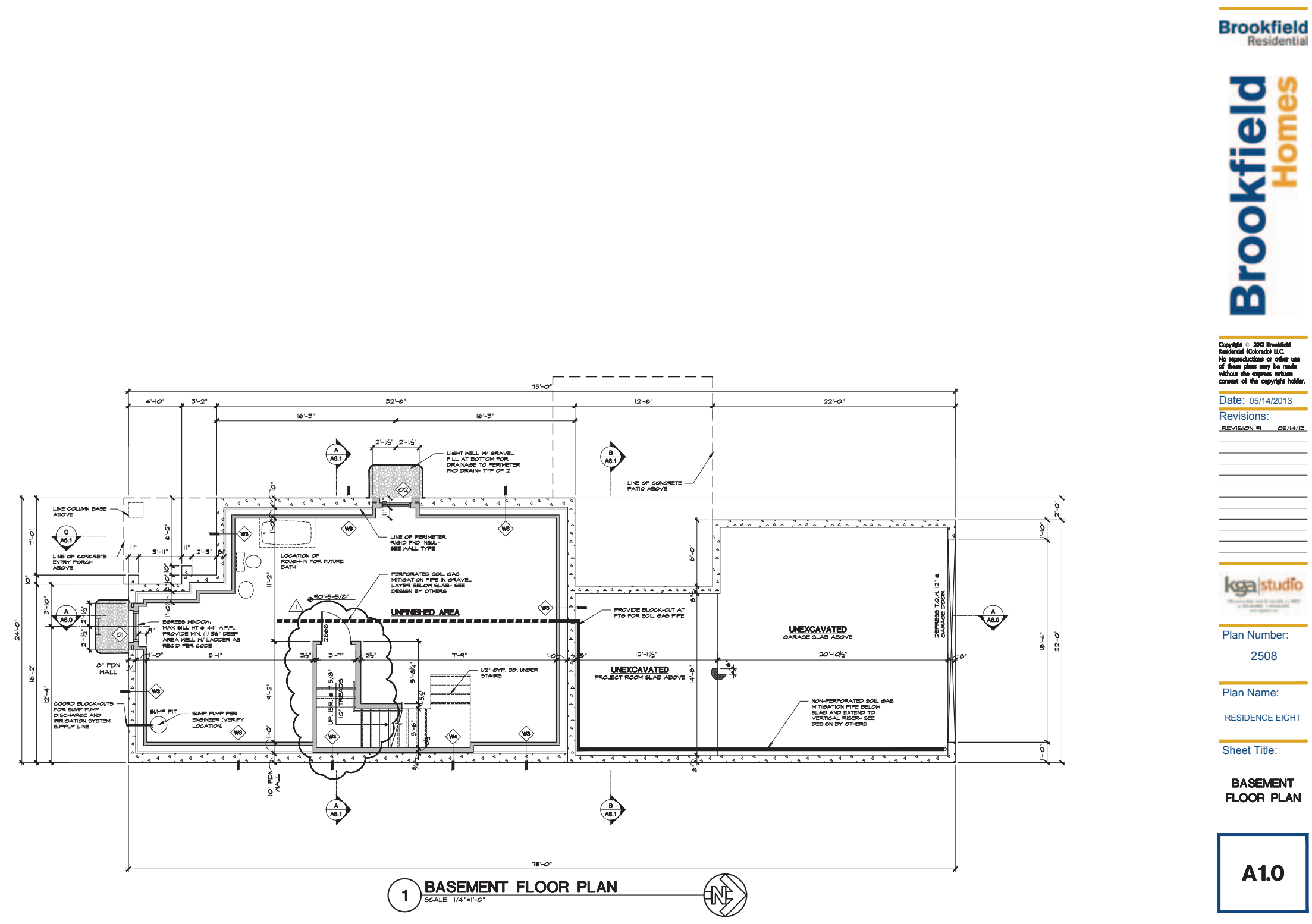




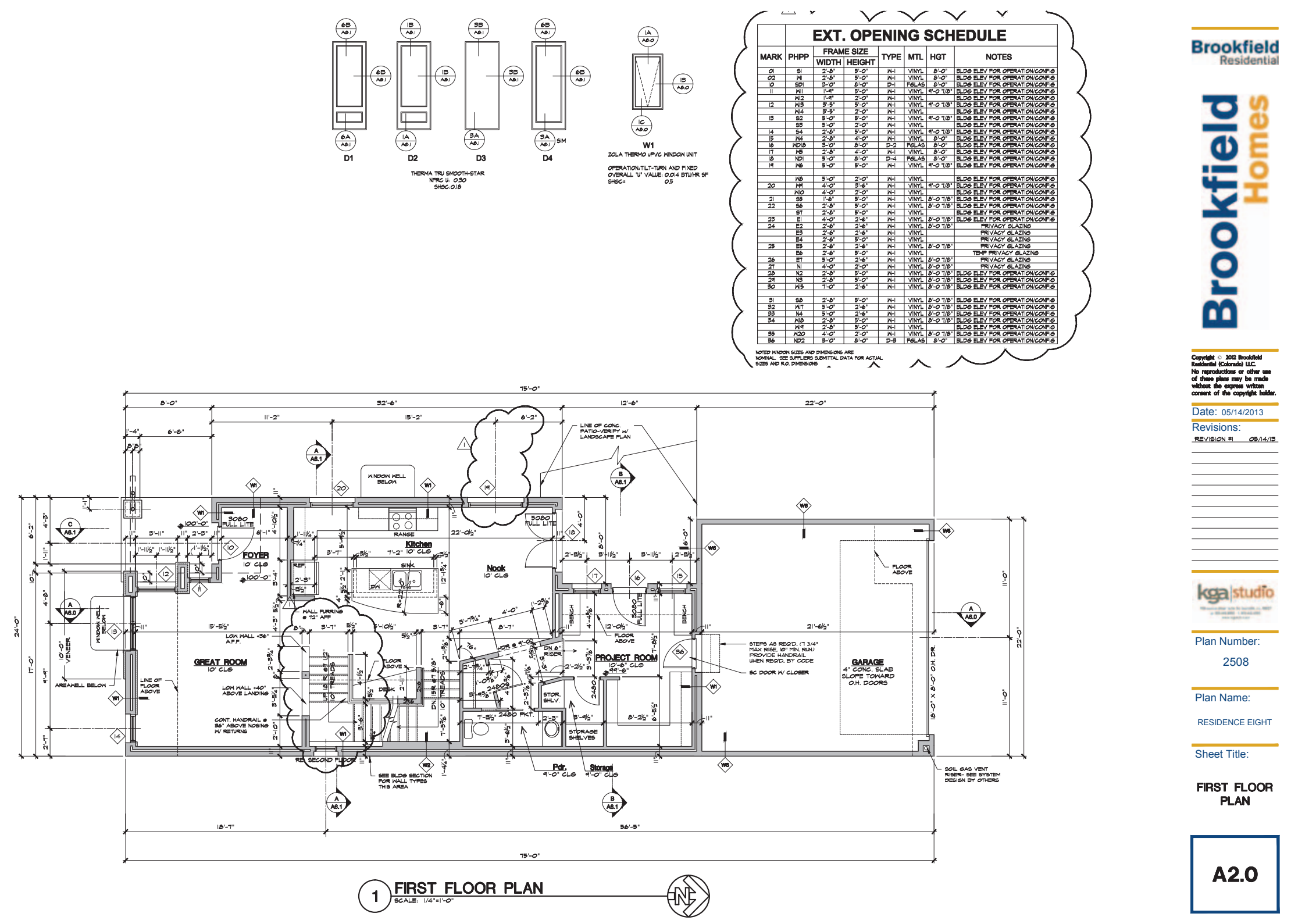



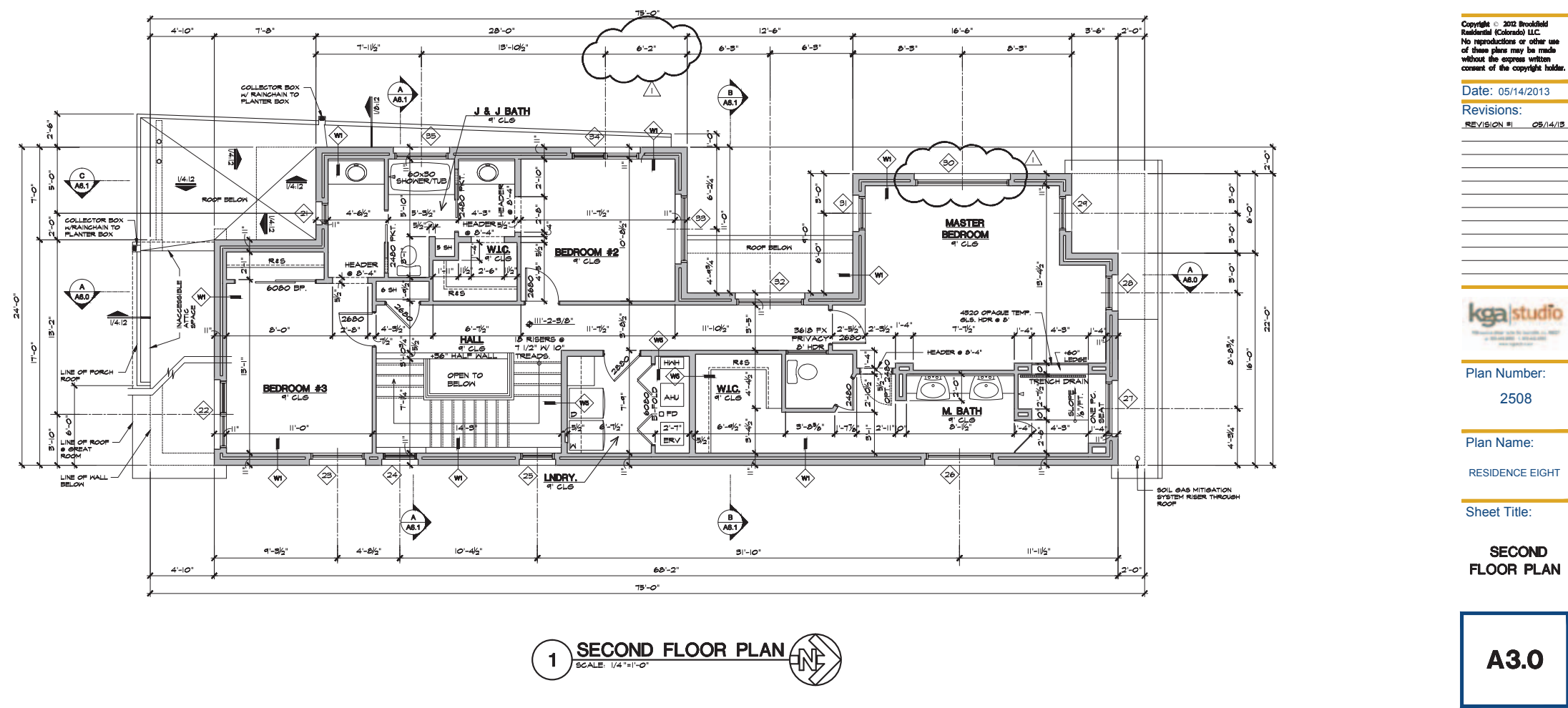

(1) SECOND FLOOR PLAN 


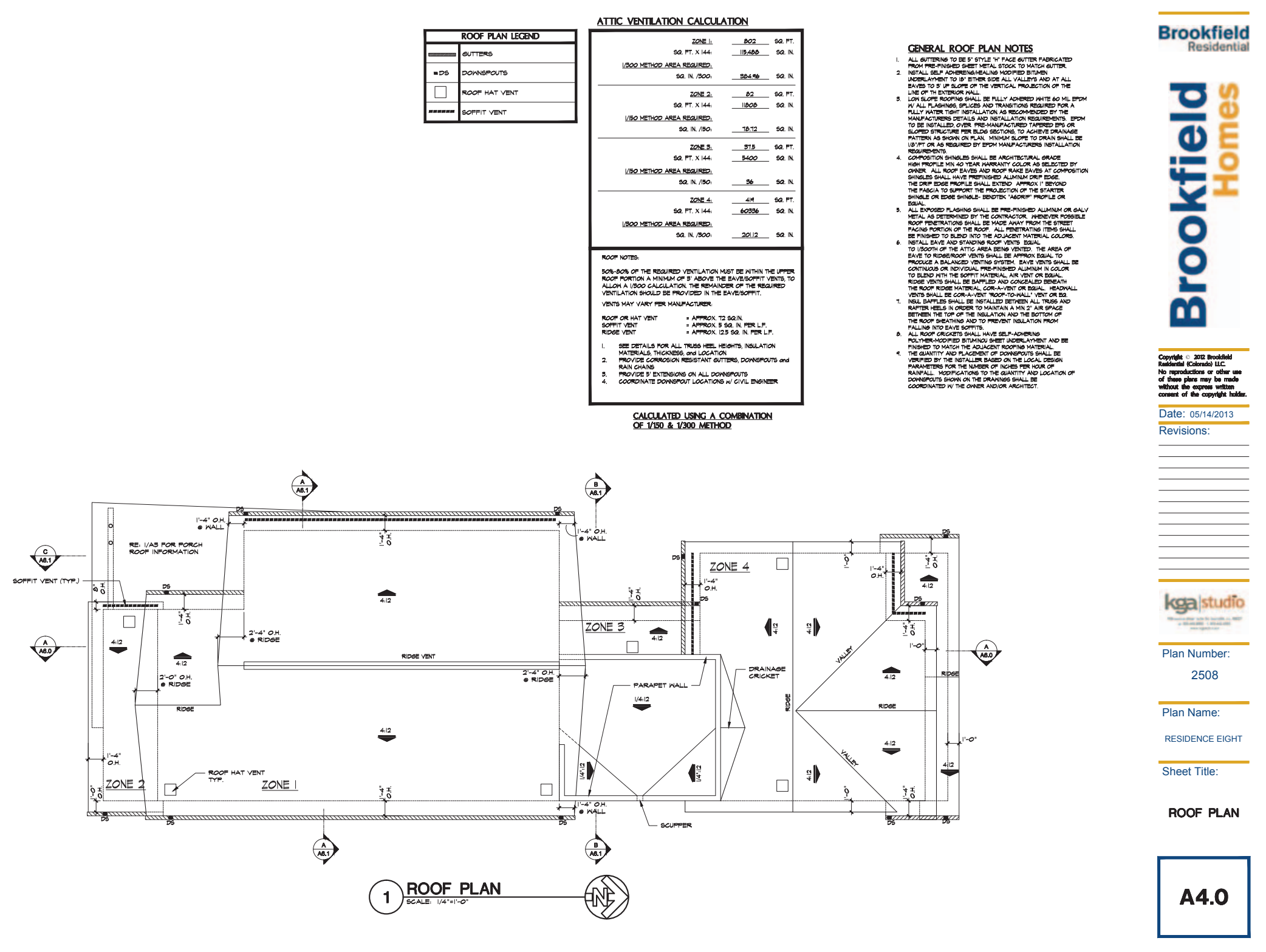




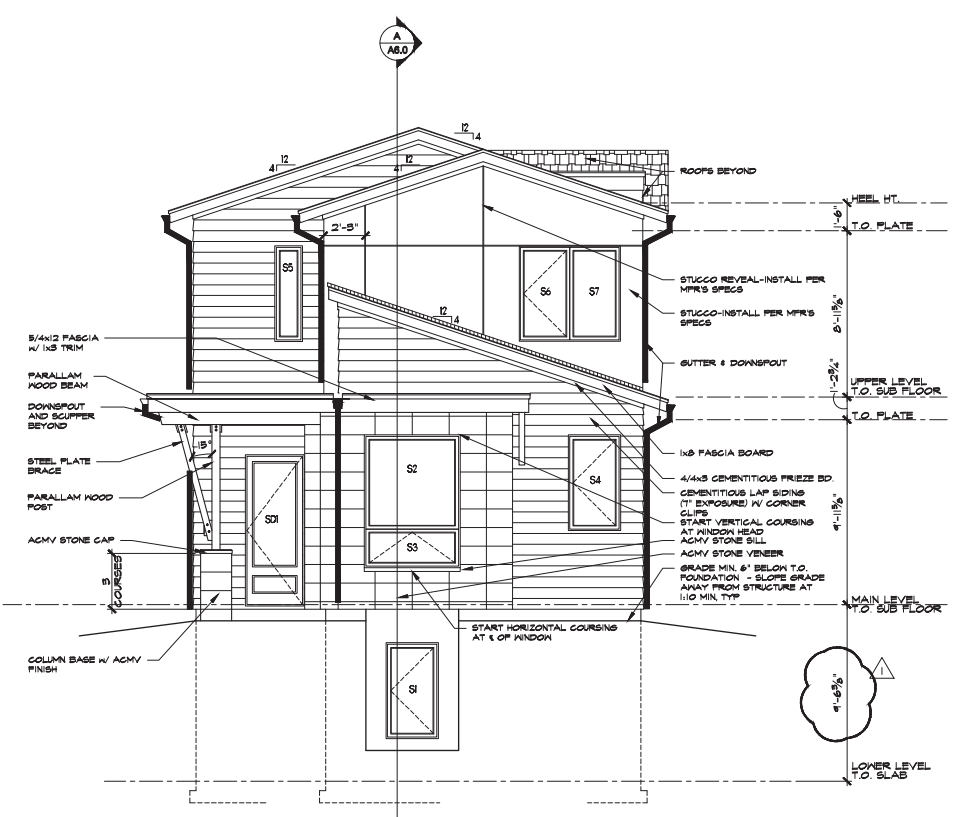

(1) SOUTH ELEVATION

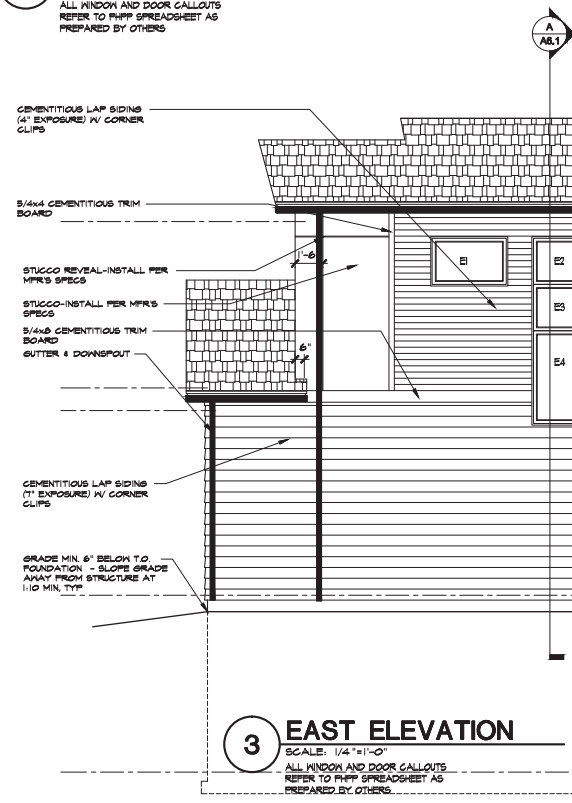

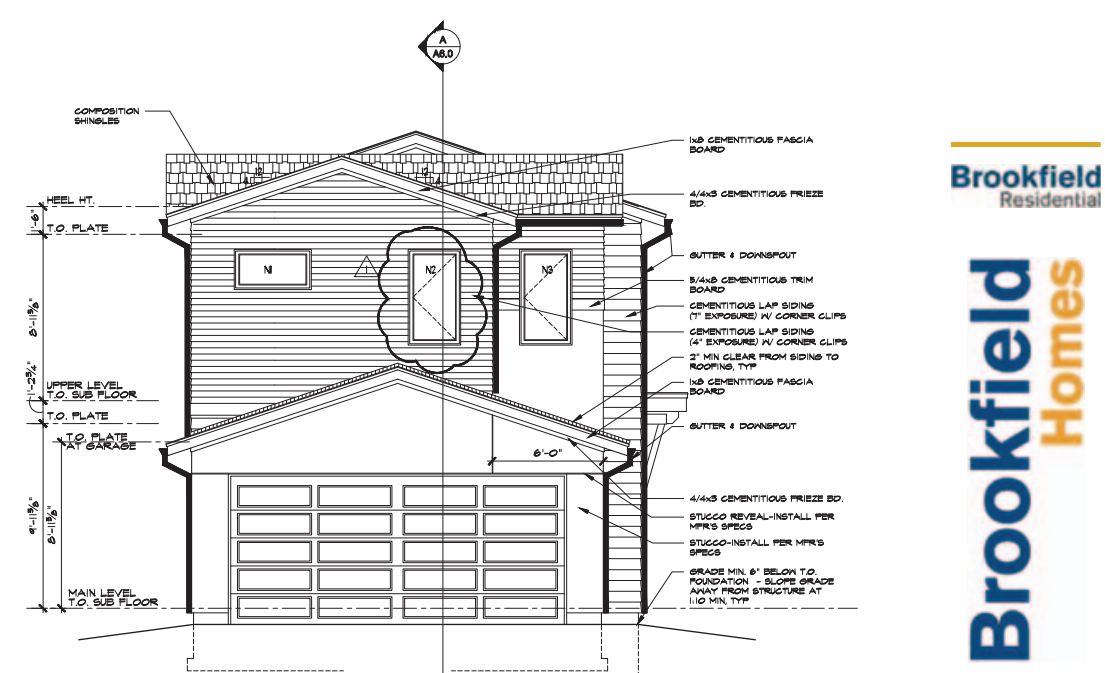

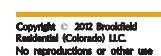
sin Date: 0514142013 Revisions:
Revision \#1 
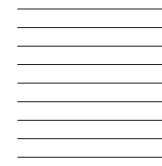

kgastudio galstudio Plan Number: 2508

Plan Name:

RESIDENCE EIGHT

Sheet Title:

BUILDING
ELEVATIONS

ELEVATIONS

A5.0 


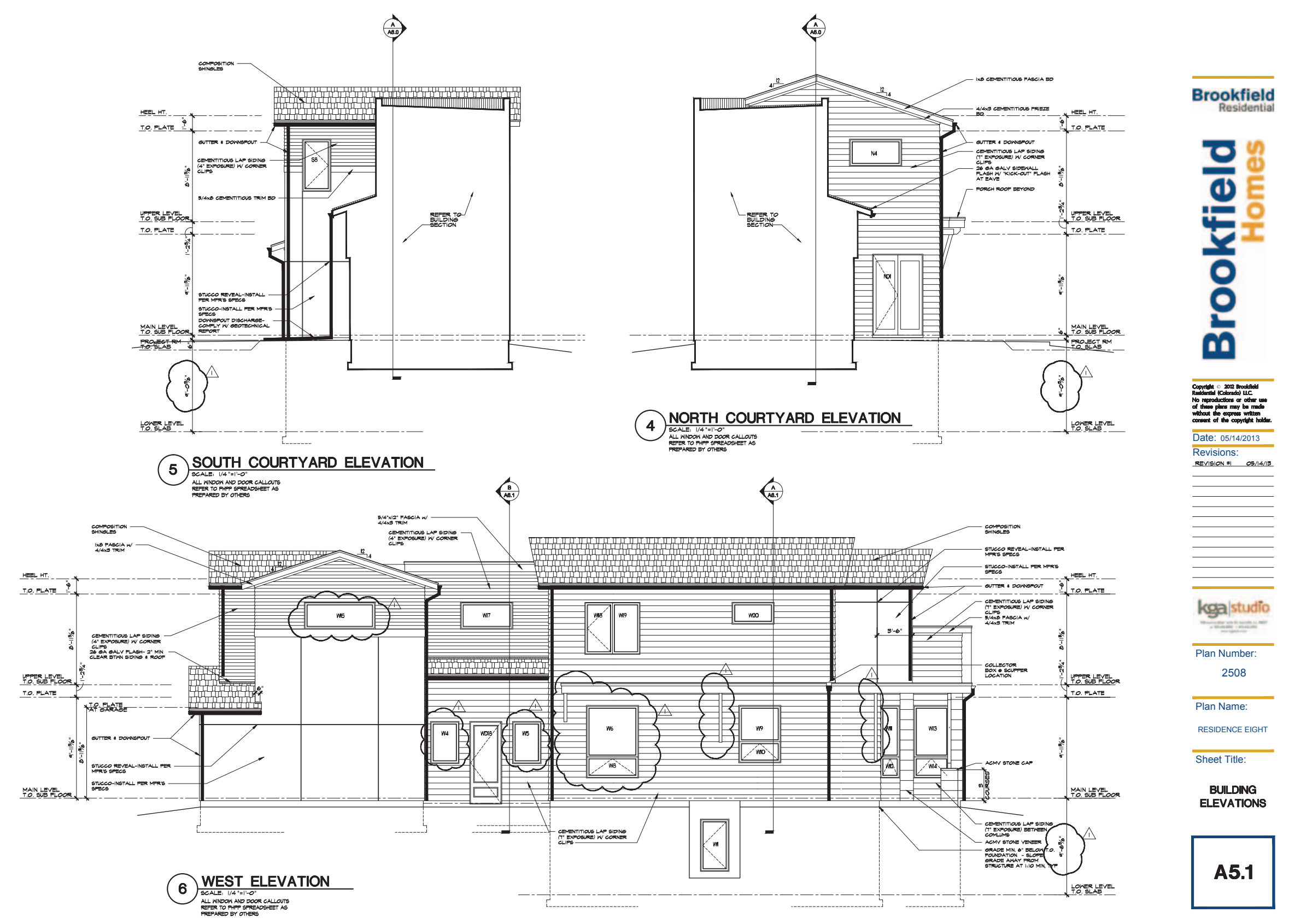



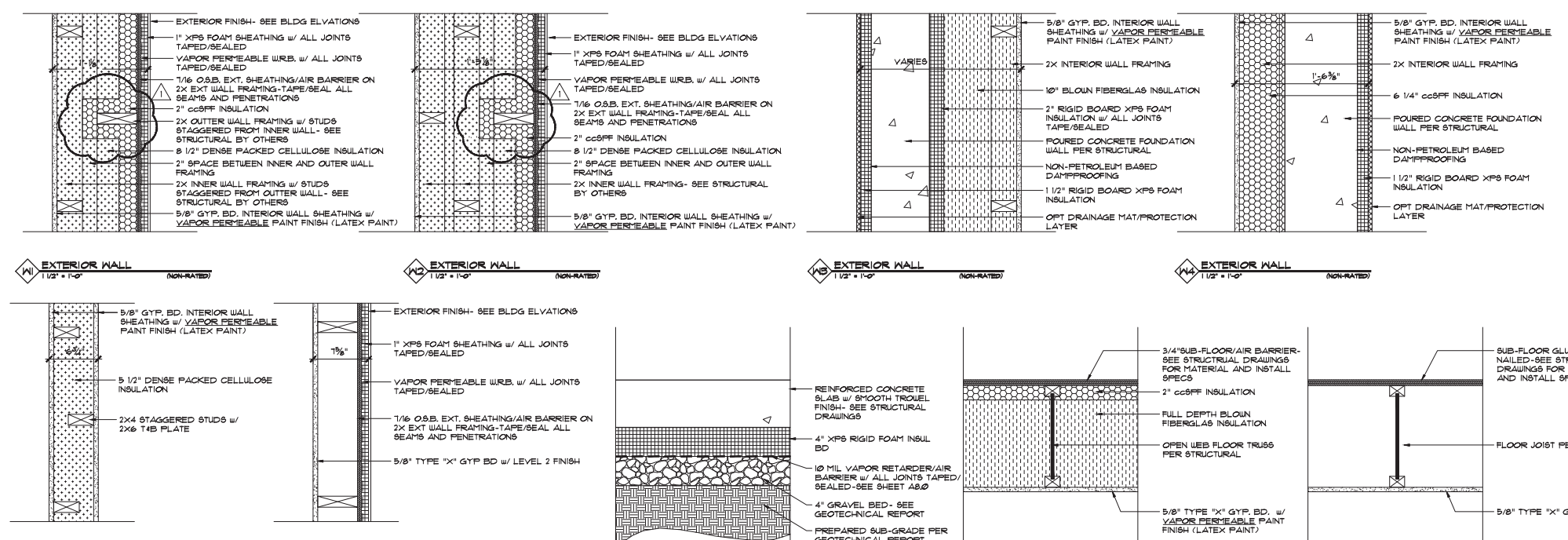

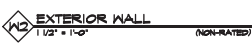

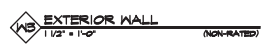

AnI EXTERIOR NALL
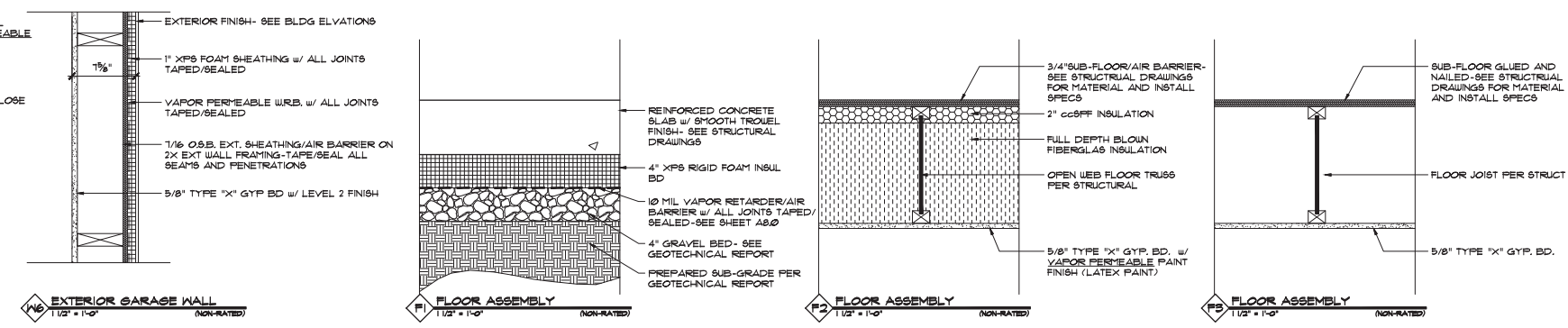

ASSEMBLY TYPES

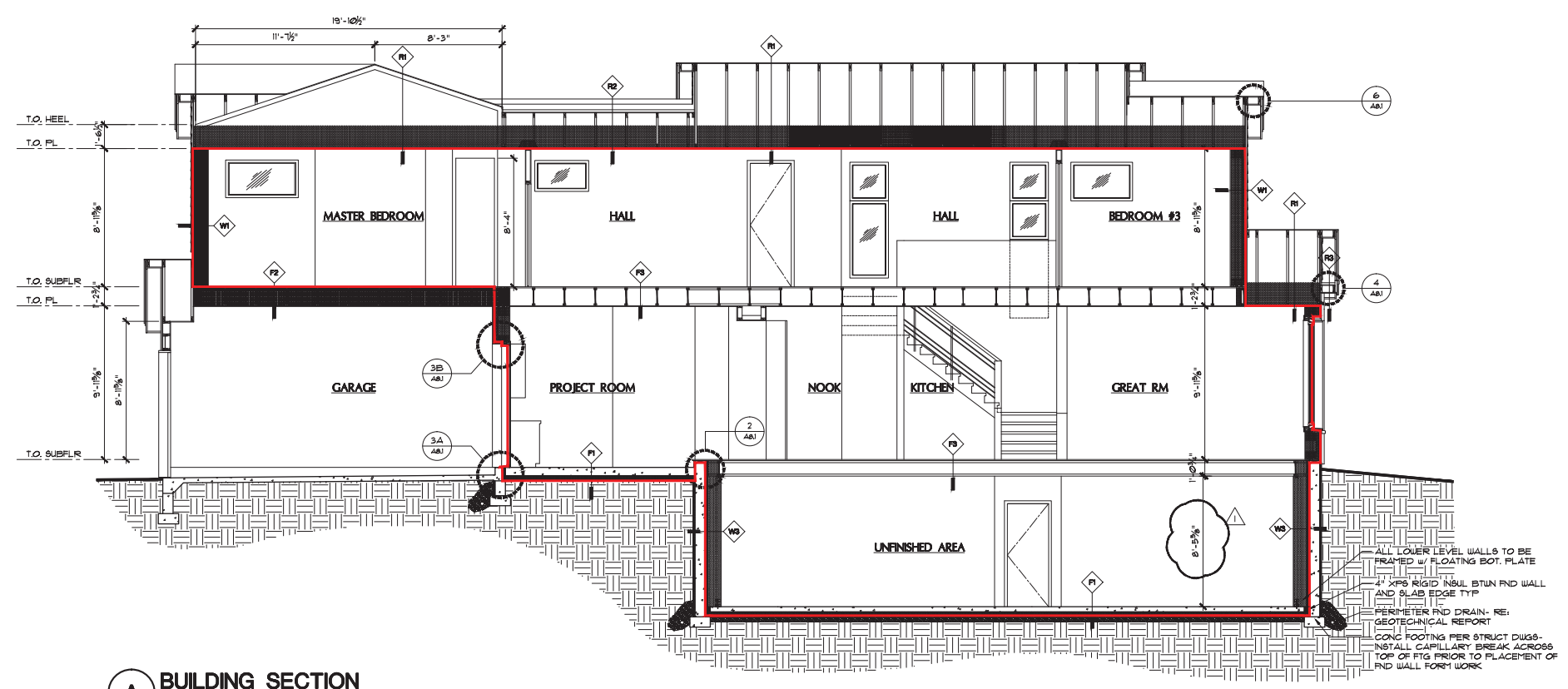

(A) BUILDING SECTION 

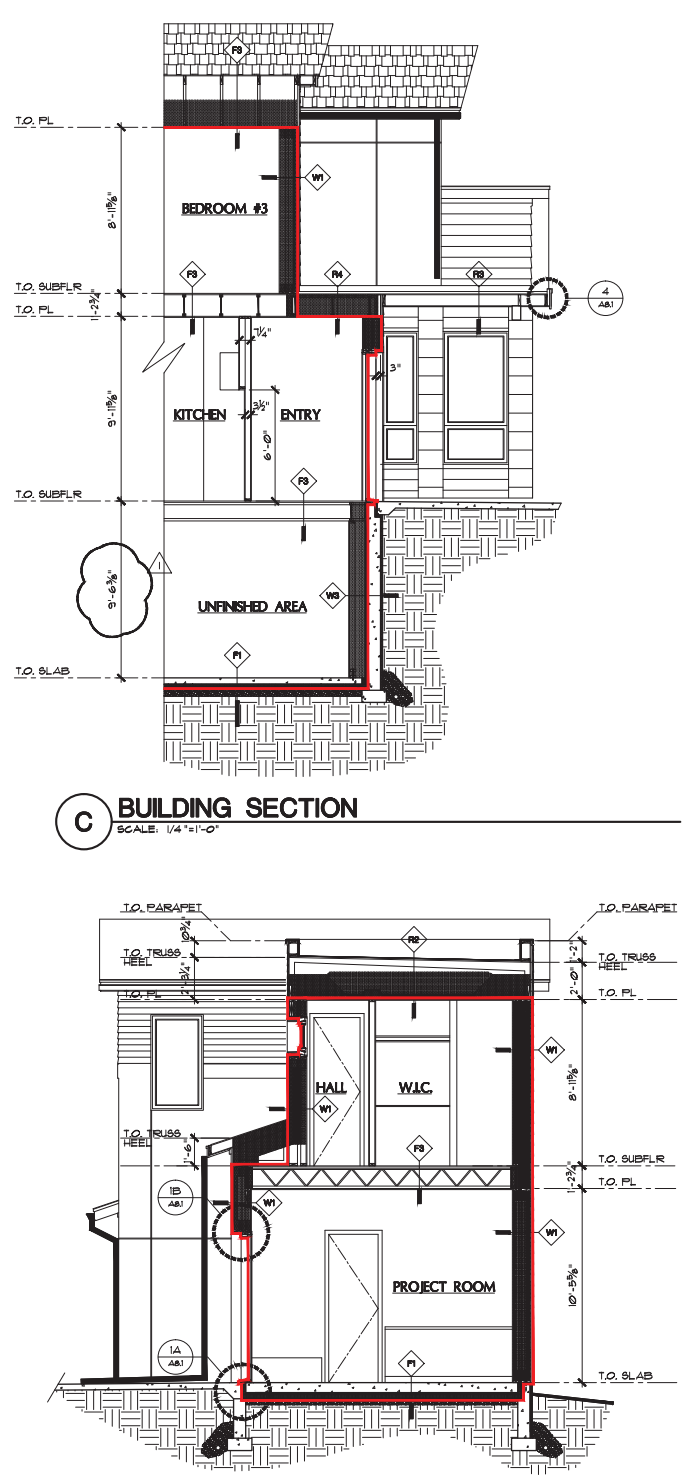

(B) BUILDING SECTION
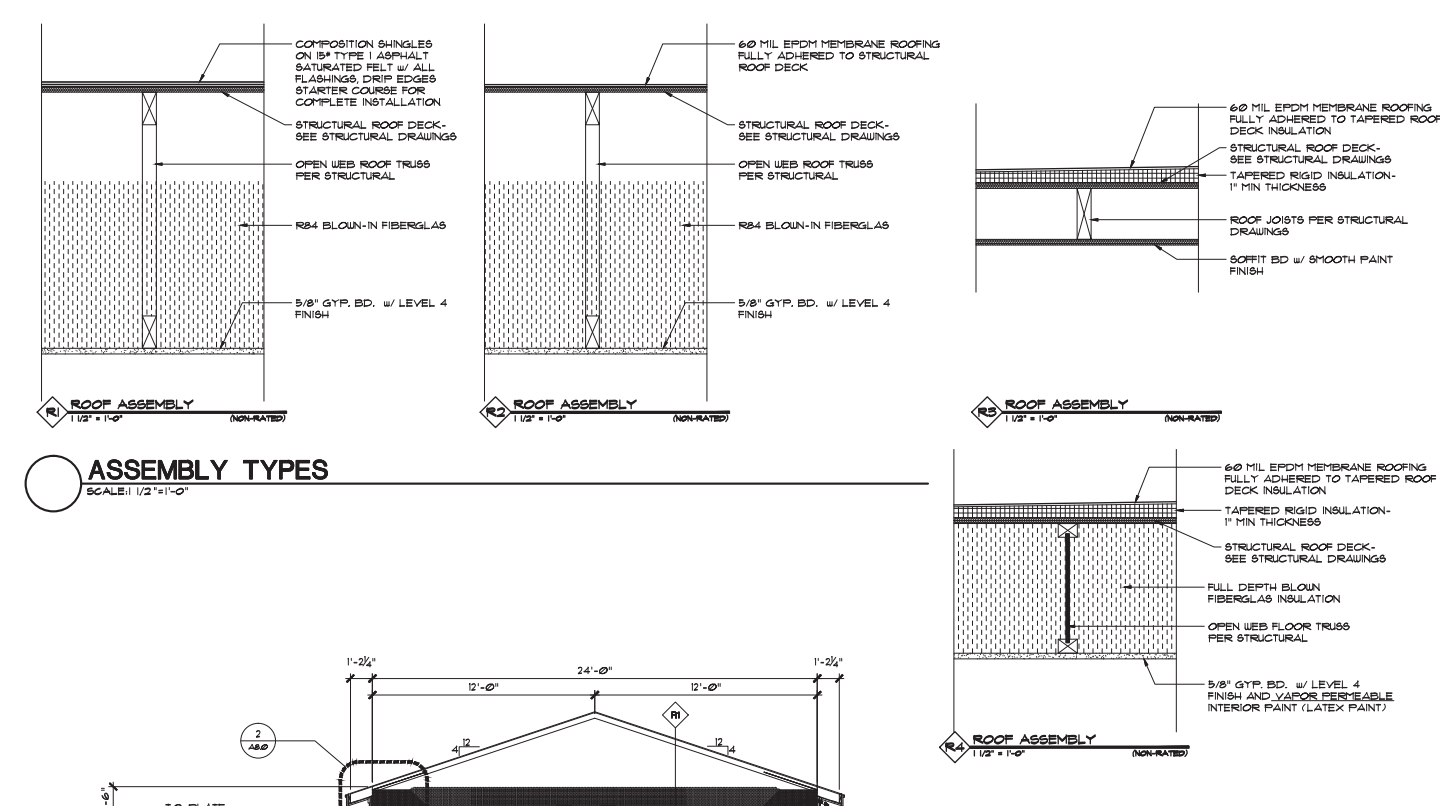

Brookfield
Residentia

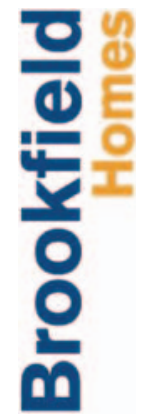

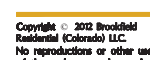

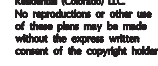
\begin{tabular}{l} 
Date: 05/14/2013 \\
\hline Revisions:
\end{tabular} Revision \#1 O5/14/13

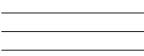

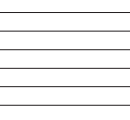

kga|studio Plan Number: 2508

Plan Name:

RESIDENCE EIGH Sheet Title: BUILDING
SECTIONS 


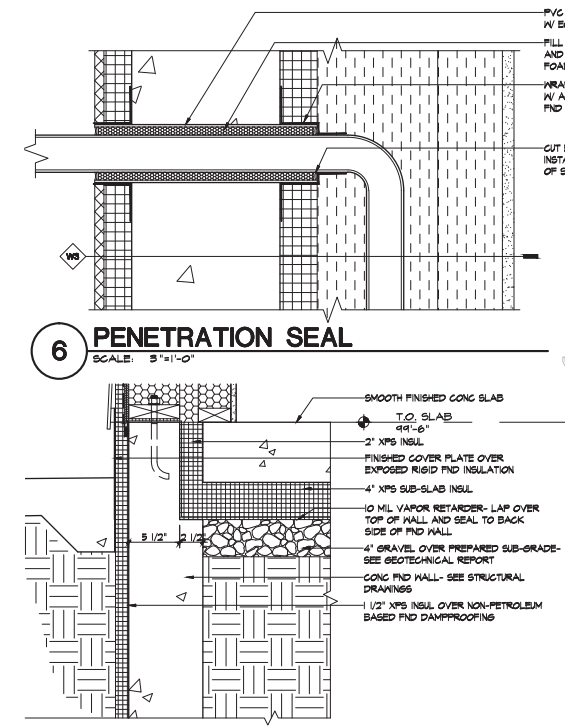

(5) SLAB-ON GRADE EDGE

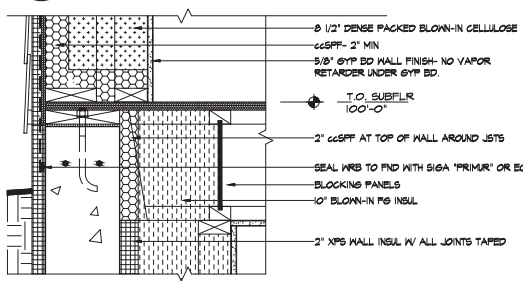

(4) PERPENDICULAR JST BEARING

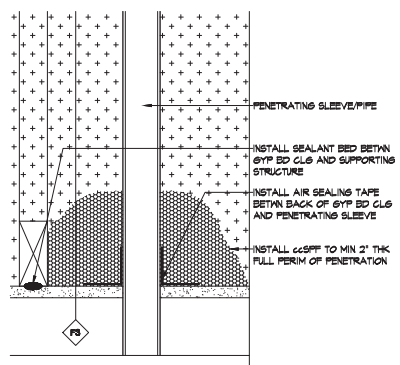

(7) PENETRATION SEAL

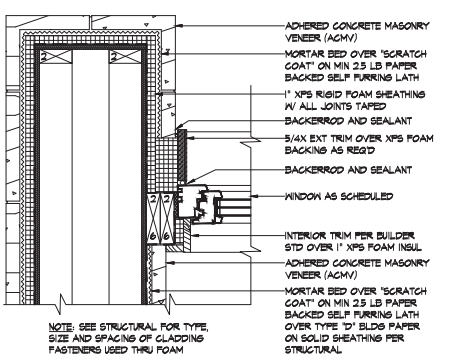

(3) PILASTER WINDOW JAMB

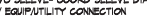

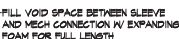

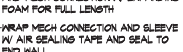

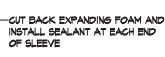
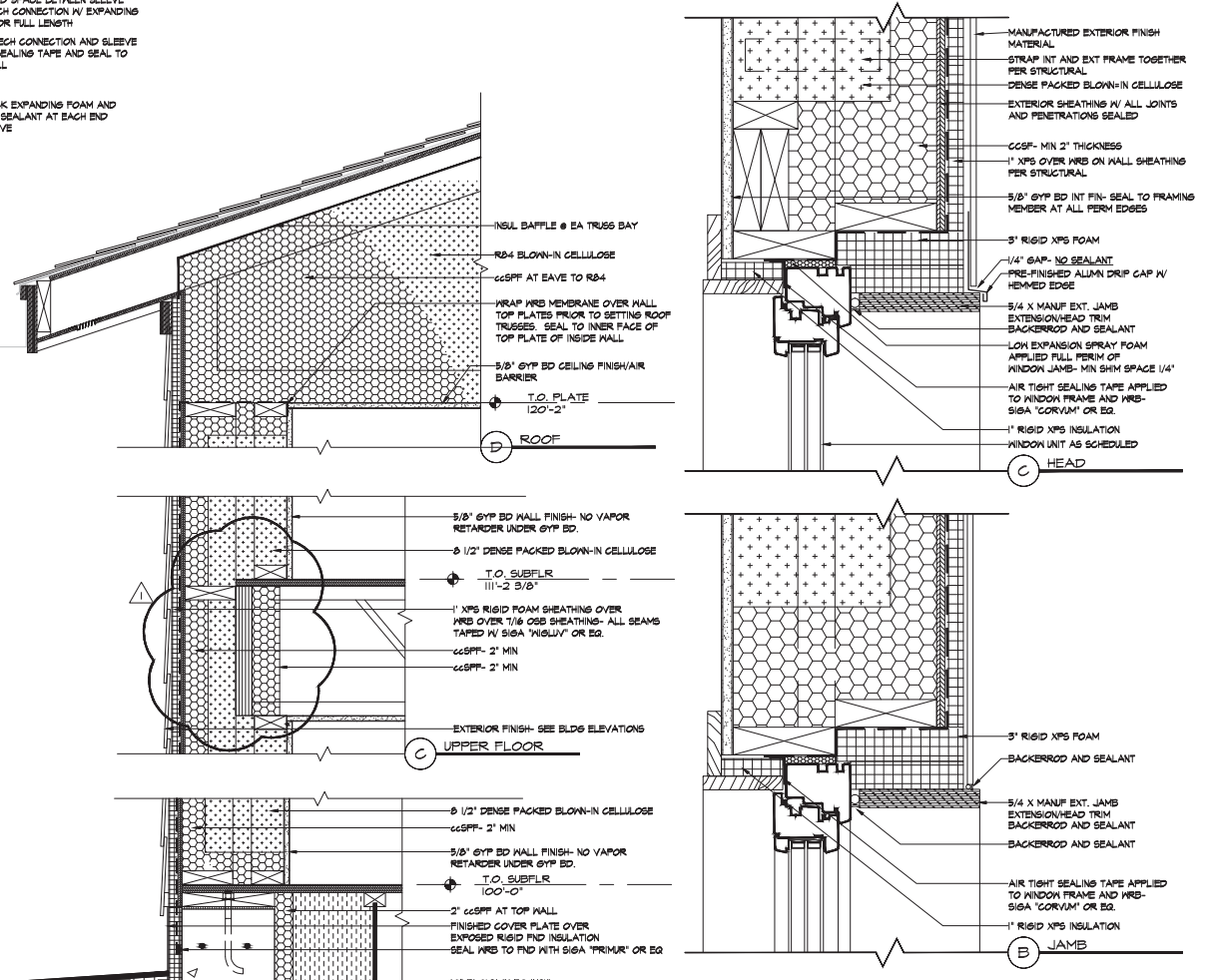

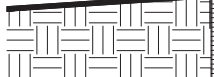
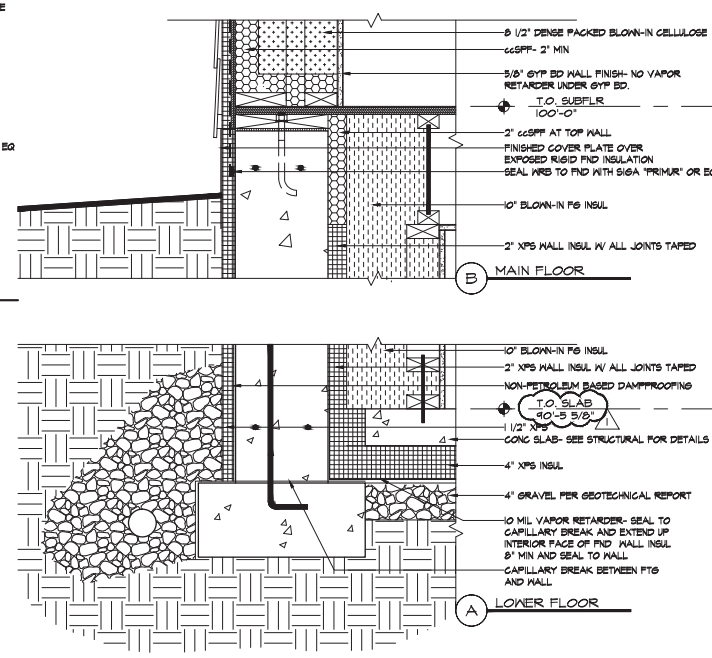

(2) EXT WALL DETAILS
Brookfield
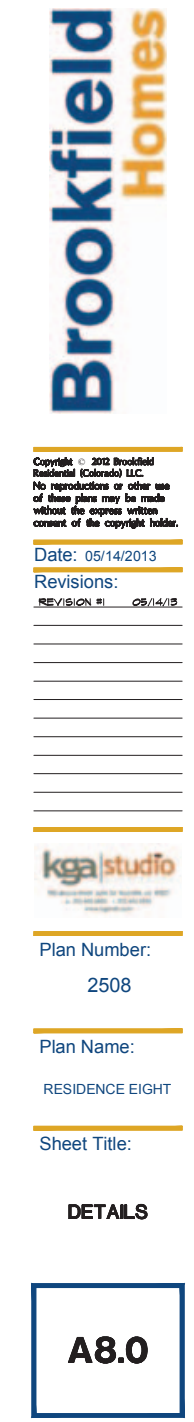


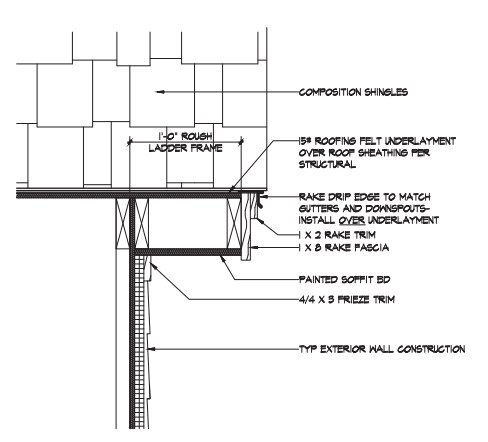

6) $\frac{H I G H}{S C O A E I V Z^{2}=1-O^{\circ}}$ SLOPE ROOF EAVE
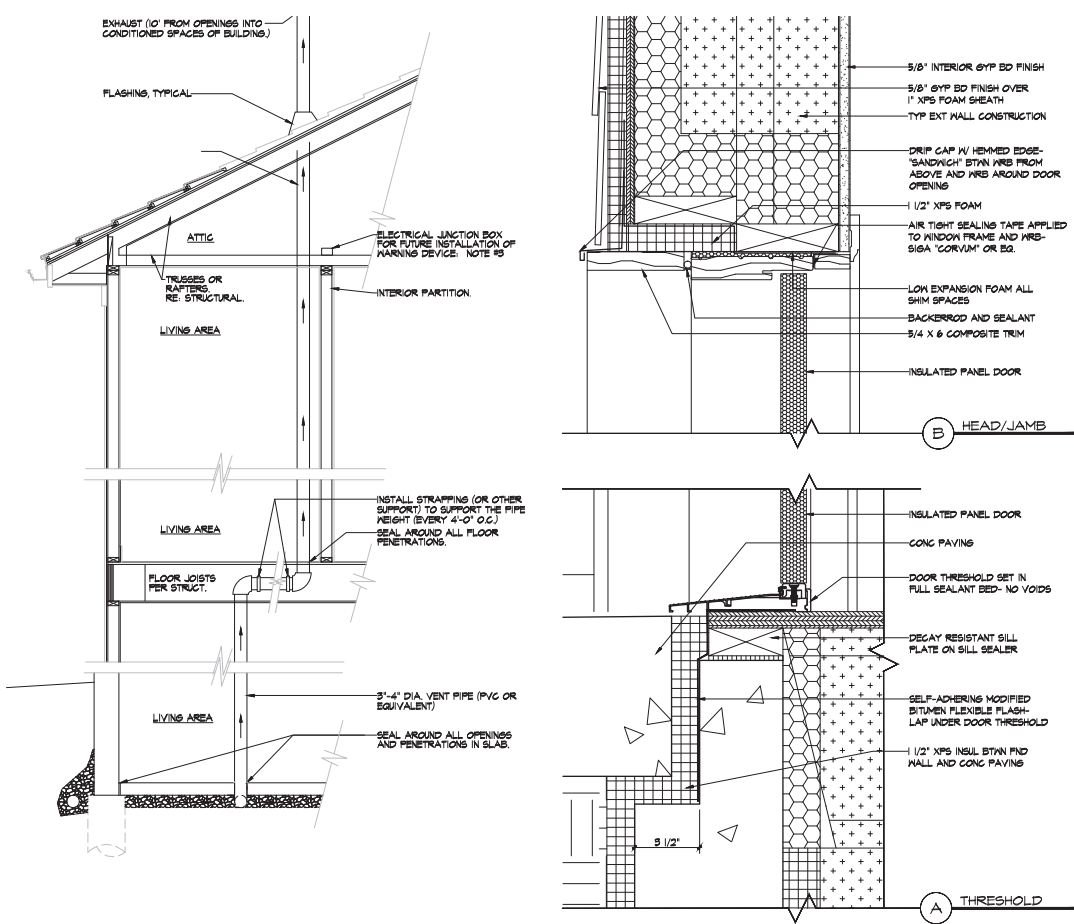

(7) SOIL GAS MITIGATION SYSTEM

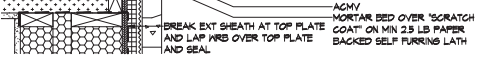
(4) LOW SLOPE ROOF EAVE
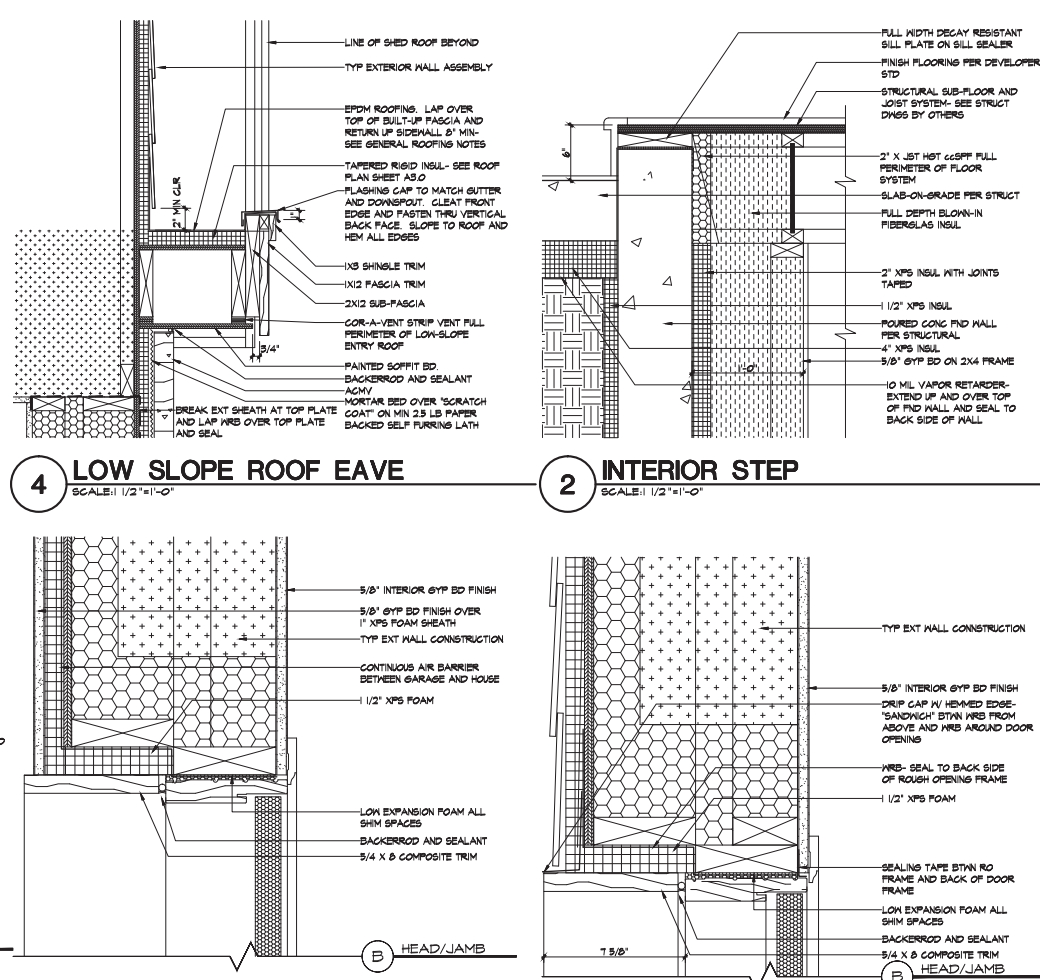

(2) INTERIOR STEP

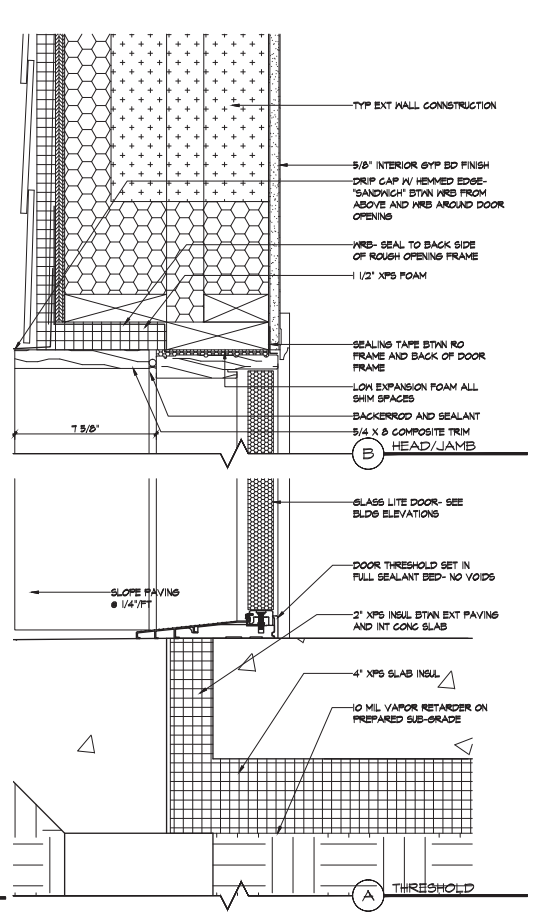

(1) PROJECT RM TO EXT DOOR
Broookfield
Residential

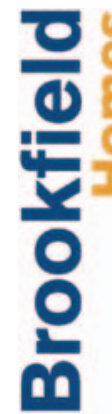

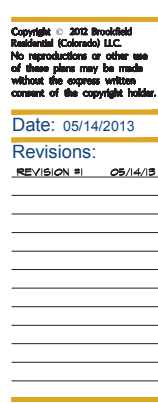

kga/studio $=$ 2508

Plan Name:

RESIDENCEEIGHT

Sheet Titte:

DETALS 


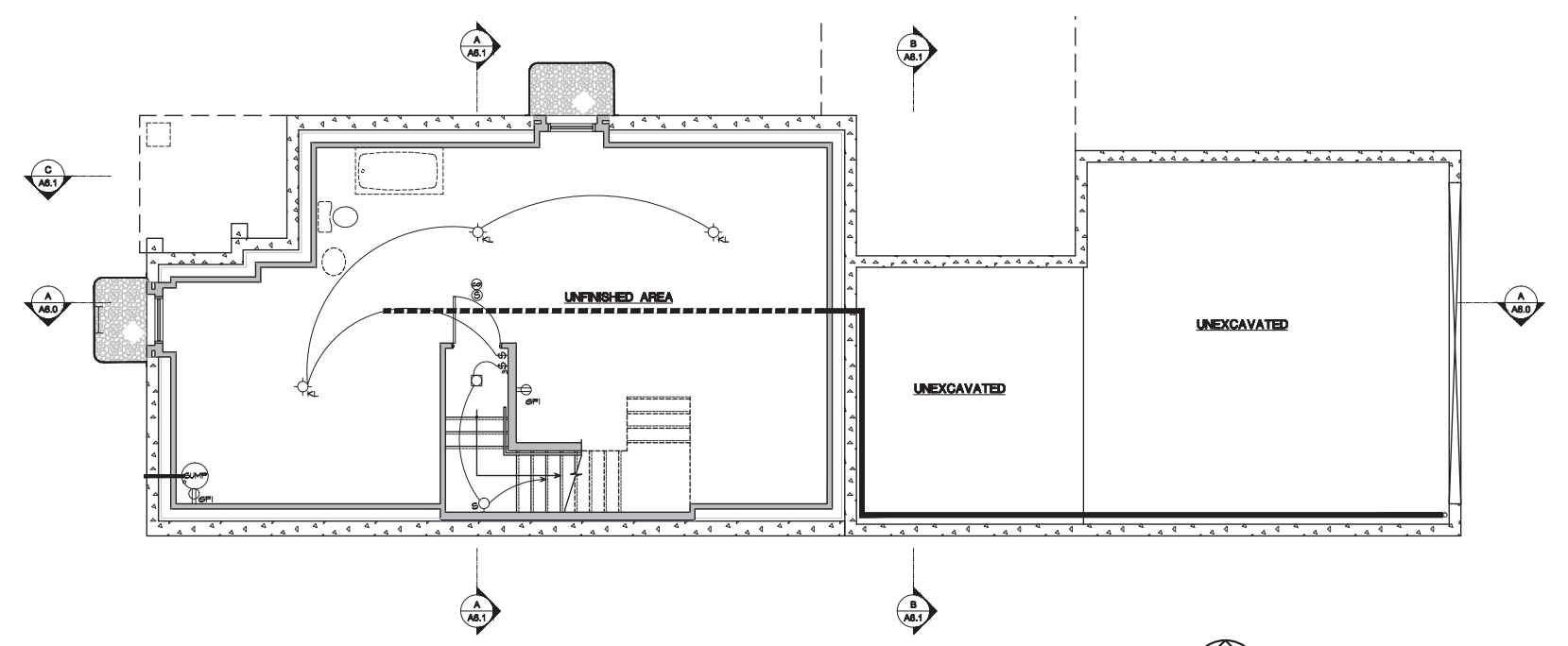

(1) BASEMENT FLOOR PLAN

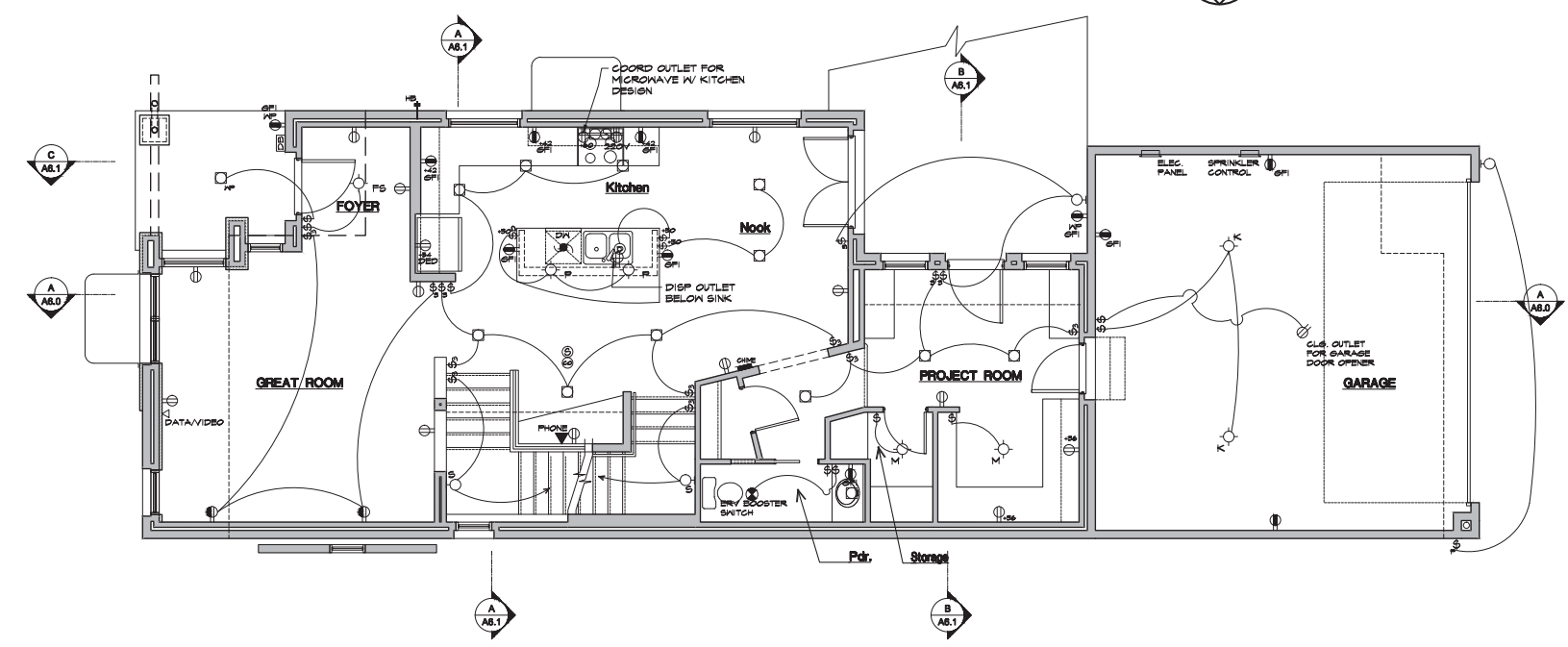

(2) FIRST FLOOR PLAN

N

\section{Electrical Legend}

- RECESED LISHT

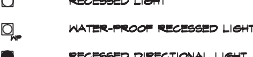

os MaL NaNreo scones

OEXTFF FRONT ENTRY COACH LIS

DO EXT-G GARAGE COACH LIOAT

O-N NOOK CHANDLUISE

Q. Dinigroom CHANDE

P. FOTER PEVANT

PFF FUSH FOTER MONTEO LGHT

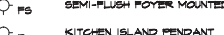

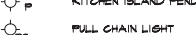

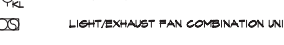

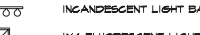

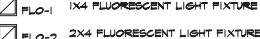

$\theta$ DUPEex aThet

$\theta_{\text {WN }}$ NEATERR PROOF DULLEX OUTET (NP)

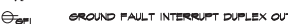

ODED DEDIAATED CIREUT OUTLET IDED

- SNITCHED DURLEX OUTET

* CELING MaNTED DUPLEX OU

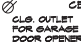

a HAROWIRED EQUIPMEN

E220V 220 VOLT OUTLET

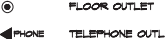

-MU⿴囗十) CABLE TN OUTLE

SMOKE DETECTOR

CAREON MNONXXE DETECTOO

DISPOSAL

LOW VOLTAGe

unction sox

TTERVOSTAT

DOOR BELL

DEECTRCAL PANE

SNGLE-POLE SWTCH

PHOTO-CELL SNITCH

OCCUPANCY SENSOR SWITC

3 MAT SNITCH

DIMMER SWITCH

Do 3 NAT DMMER SNITTE

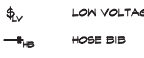




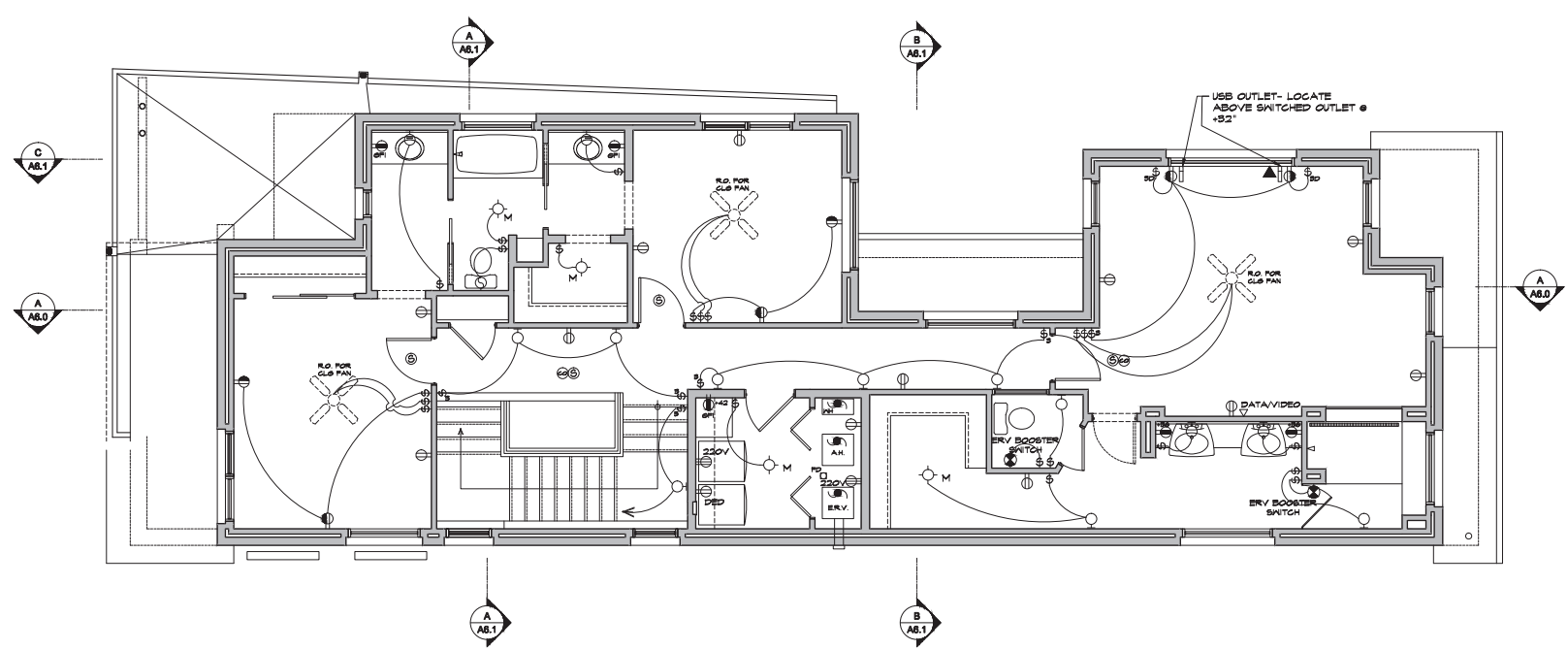

(1) SEECOND FLOOR ELEC PLAN
Electrical Legend

a RECESSED LISH

In WATER-MPOOO RECESSED LIOHT

- Recessed Directional

1) WALL MONTED SCONEE

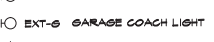

M M calino monted lor

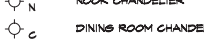

D. Forer Penant

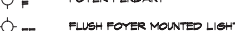

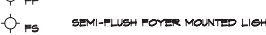

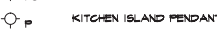

iṕc PULL CHAN LetT

Pík KELLES LIEHT FIXTURE

$\infty$

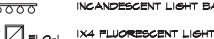

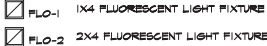

$\theta \quad$ DUVLEX OUTLT

$\theta_{\text {Ne }}$ MEATHER PROOFF DUPLEX OUTLET MNO

EOr

E DeD DEICATED CIREUT OUTLET IOED)

SNTTCHED DURLEX OUTLT

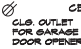

a HAROSIRED EQUivMEN

F $220 \mathrm{~V} 20 \mathrm{~V}$ VLT OUTLET

- Proor OUTLET

谓 CABLE $\mathbb{N}$ OULET

SMOKE DETECTOR

CAReon MONOX DE Detecto

DISPOSAL

LOW VOLTAGE

unction sox

TrERNOSTAT

DOOR BELL

DEECTRCAL PANEL

SNGLE-POLE SWTCH

PHOTO-CELL SNITCH

occupaner SENSOR SNIT

3 war SNiren

DMMER SWTCH

3 WAT DIMMER SNITCH

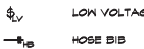

N5
Brookfield
Residential

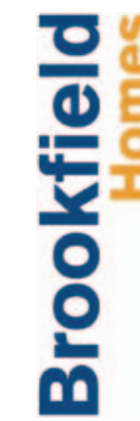

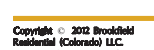

졸

Date: 05/14/2013

Revisions:
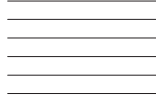

$\bar{\square}$

kga/studio

$=$

lan Number:

Plan Name:

RESIDENCE EIGHT

Sheet Title:

SECOND FLOOR ELEC

E2.0 
Appendix C: Contractor Air Conditioning Contractors of America Manual J and Manual D Calculations for the Passive House 


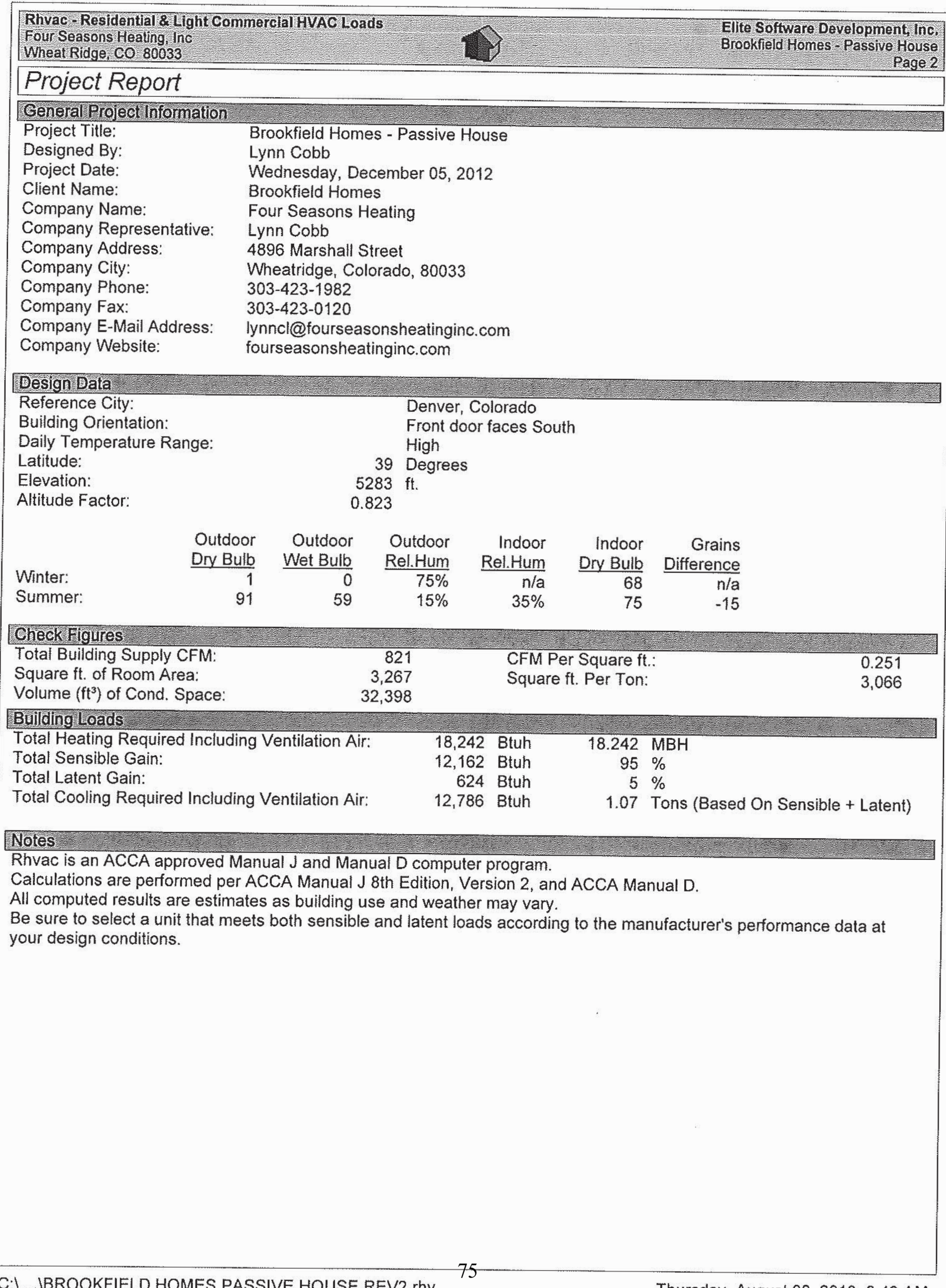




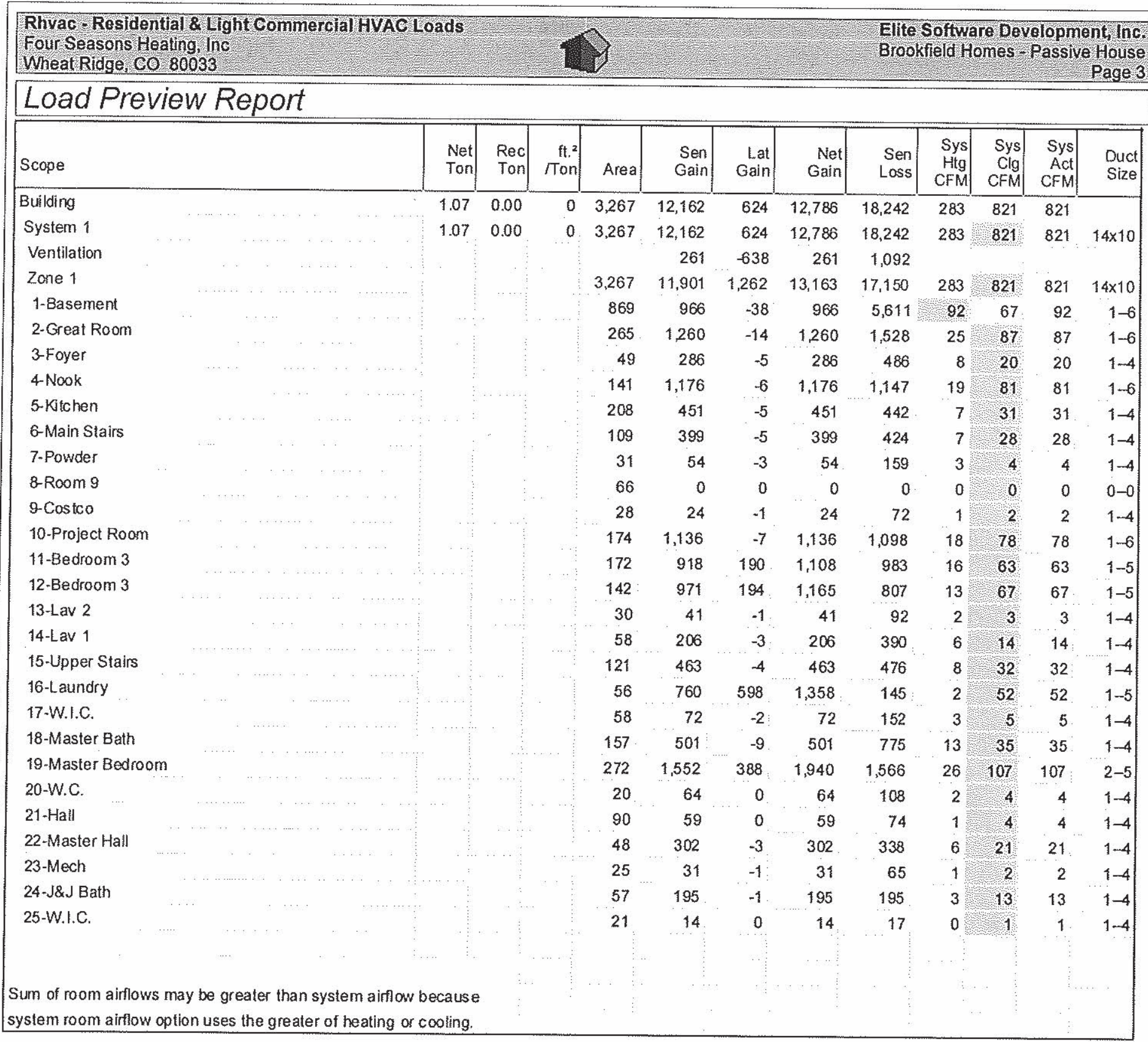




\section{Appendix D: Monitoring System Design for the Passive House}

Figure 46 through Figure 49 show the monitoring system design, including sensor locations and data collected during the long-term monitoring of the Passive House. Table 14 provides a list of the long-term monitoring equipment installed in the Passive House.

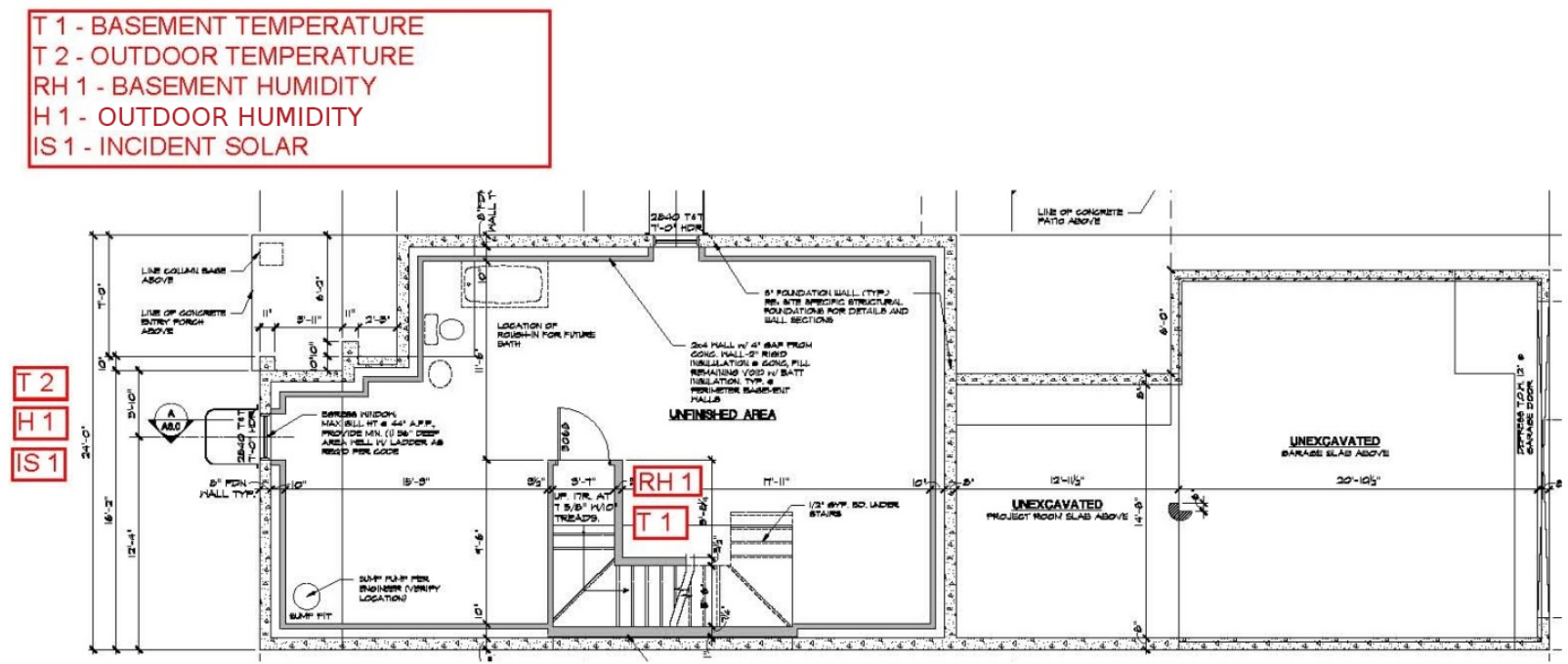

Figure 46. Sensor layout in the basement 
T 3 - GREAT ROOM TEMPERATURE

T 4 - NOOK TEMPERATURE

RH 2 - GREAT ROOM HUMIDITY

RH 3 - NOOK HUMIDITY

GFM - GAS FLOW METER

E 1 - WHOLE HOUSE ELECTRICAL

E 2 - AIR HANDLER ELECTRICAL

E 3 - HYDRONIC PUMP ELECTRICAL

E 4 - AIR CONDITIONER ELECTRICAL

E 5 - DOMESTIC HOT WATER ELECTRICAL

E 6 - ERV ELECTRICAL

E 7 - ERV PREHEATER ELECTRICAL

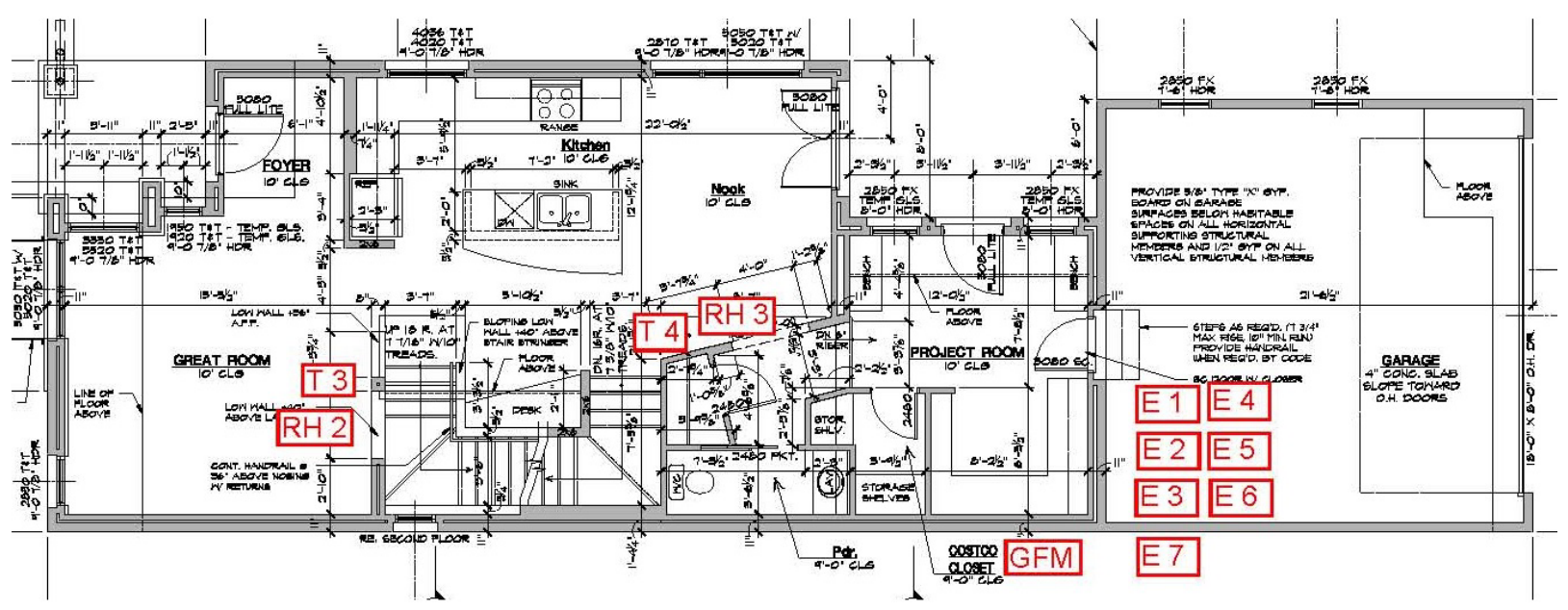

Figure 47. Sensor layout in the first floor 


\begin{tabular}{|l|}
\hline$T 5$ - BEDROOM 3 TEMPERATURE \\
T 6 - BEDROOM 2 TEMPERATURE \\
T 7 - HALL TEMPERATURE \\
T 8 - MASTER BEDROOM TEMPERATURE \\
T 9 - ERV BEFORE PREHEAT TEMPERATURE \\
T 10 - ERV AFTER PREHEAT TEMPERATURE \\
T 11 - ERV EXHAUST TEMPERATURE \\
T 12 - ERV SUPPLY AFTER CORE TEMPERATURE \\
T 13 - ERV SUPPLY BEFORE CORE TEMPERATURE \\
RH 4 - BEDROOM 3 HUMIDITY \\
RH 5 - BEDROOM 2 HUMIDITY \\
RH 6 - HALL HUMIDITY \\
RH 7 - MASTER BEDROOM HUMIDITY \\
\hline
\end{tabular}

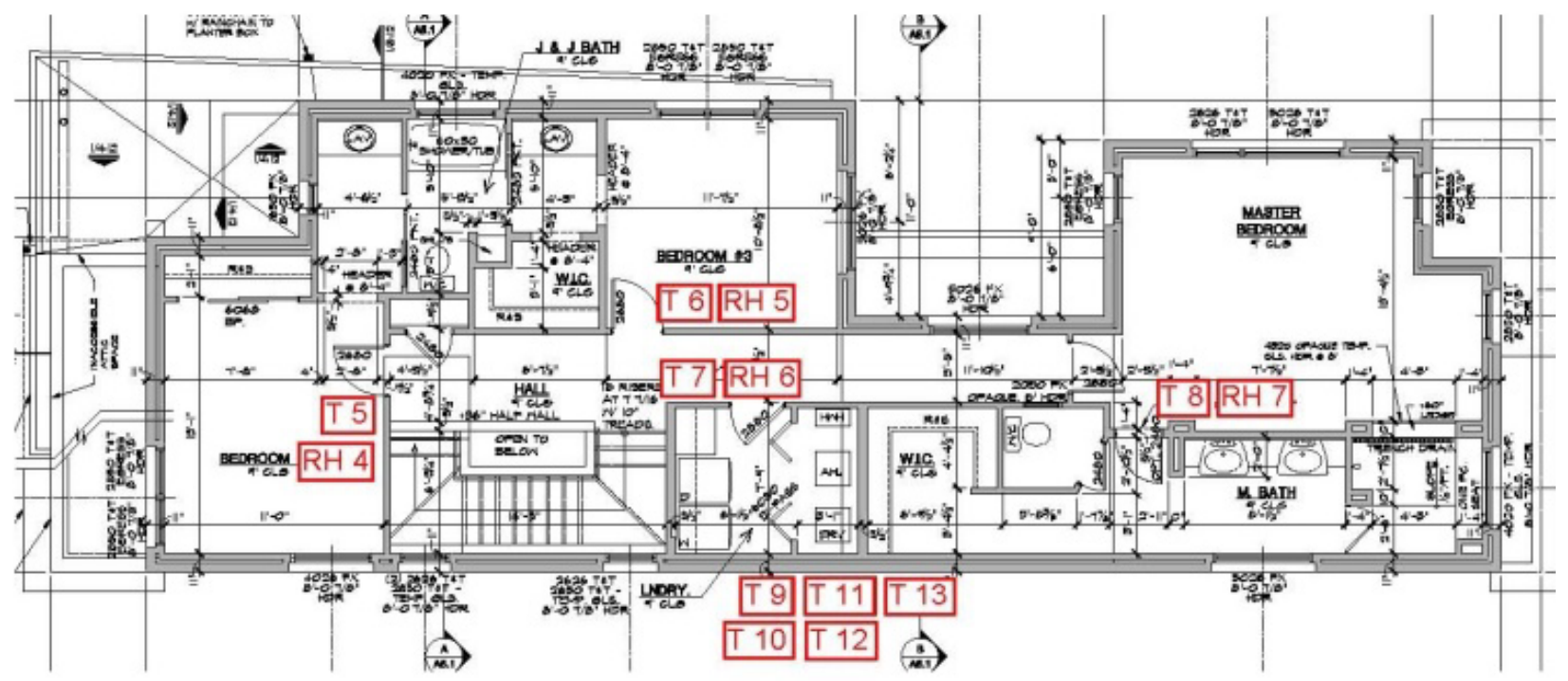

Figure 48. Sensor layout in the second floor 


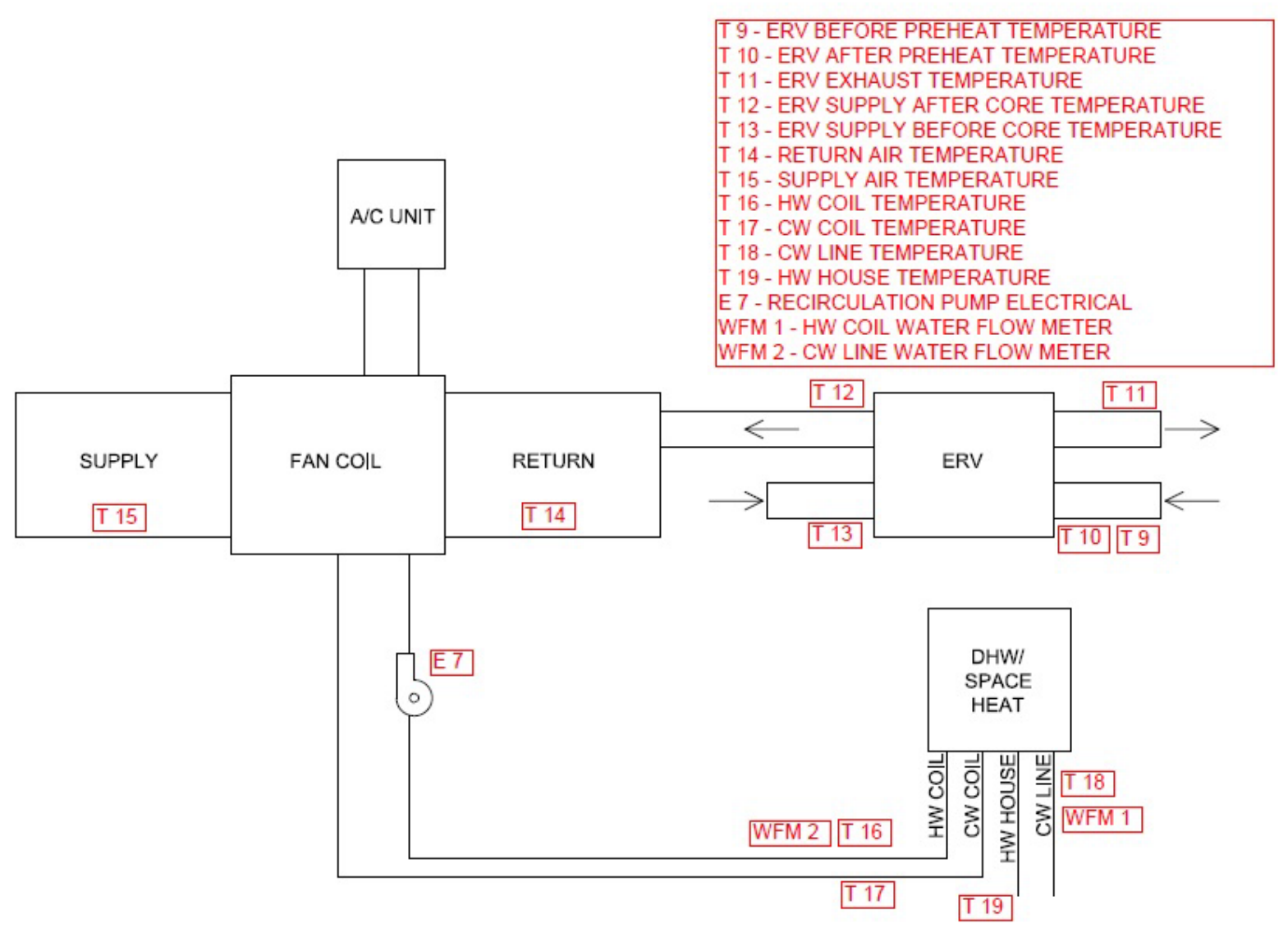

Figure 49. Sensor layout on the HVAC system 
Table 14. Long-Term Monitoring Equipment Installed in the Passive House

\begin{tabular}{|c|c|c|c|c|}
\hline Measurement & Equipment & Manufacturer & Part Number & Accuracy \\
\hline $\begin{array}{c}\text { Space Air } \\
\text { Temperature and } \\
\text { Relative Humidity }\end{array}$ & $\begin{array}{l}\text { Wireless } \\
\text { Humidity } \\
\text { Sensor }\end{array}$ & Monnit & SCM-91A-0HA & $\pm 2 \%$ \\
\hline $\begin{array}{l}\text { Supply and Return } \\
\text { Relative Humidity }\end{array}$ & $\begin{array}{l}\text { Wireless } \\
\text { Humidity } \\
\text { Sensor }\end{array}$ & Monnit & MNS-9-HA-IN-ST & $\pm 1.8 \%$ \\
\hline $\begin{array}{l}\text { ERV Supply and } \\
\text { Return Air } \\
\text { Temperature and } \\
\text { Relative Humidity }\end{array}$ & $\begin{array}{l}\text { Wireless } \\
\text { Humidity } \\
\text { Sensor }\end{array}$ & Monnit & MNS-9-HA-IN-ST & $\pm 1.8 \%$ \\
\hline $\begin{array}{c}\text { Supply and Return } \\
\text { Temperature }\end{array}$ & $\begin{array}{l}\text { Wireless } \\
\text { Humidity } \\
\text { Sensor }\end{array}$ & Monnit & MNS-9-HA-IN-ST & $\pm 0.4^{\circ} \mathrm{C}$ \\
\hline $\begin{array}{c}\text { Temperature of Hot } \\
\text { Water from Hydronic } \\
\text { Coil }\end{array}$ & $\begin{array}{c}\text { Wireless } \\
\text { Temperature } \\
\text { Sensor }\end{array}$ & Monnit & MNS-9-TS-W2-LD & $\pm 1^{\circ} \mathrm{C}$ \\
\hline $\begin{array}{l}\text { Temperature of Cold } \\
\text { Water into Boiler }\end{array}$ & $\begin{array}{c}\text { Wireless } \\
\text { Temperature } \\
\text { Sensor }\end{array}$ & Monnit & MNS-9-TS-W2-LD & $\pm 1^{\circ} \mathrm{C}$ \\
\hline Data Collection & $\begin{array}{l}\text { Wireless } \\
\text { Gateway }\end{array}$ & Monnit & CGW2 & NA \\
\hline
\end{tabular}


Appendix E: IBACOS Air Conditioning Contractors of America Manual J Calculations for the Passive House 


\section{Project Information}

For: Brookfield passive house

\section{Design Information}

$\begin{array}{lccl} & \text { Htg } & \text { Clg } & \\ \text { Outside db }\left({ }^{\circ} \mathrm{F}\right) & 7 & 92 & \text { Method } \\ \text { Inside db }\left({ }^{\circ} \mathrm{F}\right) & 70 & 75 & \text { Construction quality } \\ \text { Design TD }\left({ }^{\circ} \mathrm{F}\right) & 63 & 17 & \text { Fireplaces } \\ \text { Daily range } & - & \mathrm{H} & \\ \text { Inside humidity (\%) } & 30 & 50 & \\ \text { Moisture difference }(\mathrm{gr} / \mathrm{lb}) & 32 & -36 & \end{array}$

Infiltration

Simplified

Tight

0

\section{HEATING EQUIPMENT}

Make

Trade

Model

AHRI ref

Efficiency

Heating input

Heating output

Temperature rise

Actual air flow

Air flow factor

Static pressure

Space thermostat

$\begin{array}{rll} & & \text { Make } \\ & & \text { Trade } \\ & \text { Cond } \\ & & \text { Coil } \\ & & \text { AHRI ref } \\ & & \text { Efficiency } \\ 80 \text { AFUE } & & \text { Sensible cooling } \\ 0 & \text { Btuh } & \text { Latent cooling } \\ 0 & \text { Btuh } & \text { Total cooling } \\ 0 & { }^{\circ} \mathrm{F} & \text { Actual air flow } \\ 797 & \mathrm{cfm} & \text { Air flow factor } \\ 0.052 & \mathrm{cfm} / \text { Btuh } & \text { Static pressure } \\ 0 & \text { in H2O } & \text { Load sensible heat ratio }\end{array}$

\section{COOLING EQUIPMENT}

Make

Trade

Cond

AHRI ref

Efficiency

Sensible cooling

Air flow factor

Load sensible heat ratio

\begin{tabular}{|c|c|c|c|c|c|}
\hline ROOM NAME & $\begin{array}{l}\text { Area } \\
\left(\mathrm{ft}^{2}\right)\end{array}$ & $\begin{array}{l}\text { Htg load } \\
\text { (Btuh) }\end{array}$ & $\begin{array}{l}\text { Clg load } \\
\text { (Btuh) }\end{array}$ & $\begin{array}{l}\text { Htg AVF } \\
(\mathrm{cfm})\end{array}$ & $\begin{array}{l}\text { Clg AVF } \\
(\mathrm{cfm})\end{array}$ \\
\hline Basement & 876 & 2285 & 1209 & 118 & 67 \\
\hline Foyer & 49 & 588 & 422 & 30 & 23 \\
\hline Great Room & 255 & 1531 & 2197 & 79 & 122 \\
\hline Kitchen & 126 & 438 & 1435 & 23 & 80 \\
\hline Stairs & 109 & 434 & 151 & 22 & 8 \\
\hline Hall 1 & 102 & 0 & 0 & 0 & 0 \\
\hline Nook & 150 & 1276 & 2057 & 66 & 114 \\
\hline Toilet 1 & 114 & 273 & 44 & 14 & 2 \\
\hline Project Room & 174 & 1817 & 949 & 94 & 53 \\
\hline Garage & 462 & 0 & 0 & 0 & 0 \\
\hline Master Bedroom & 257 & 1655 & 1557 & 86 & 86 \\
\hline M Bath & 146 & 943 & 632 & 49 & 35 \\
\hline MWIC & 60 & 201 & 69 & 10 & 4 \\
\hline Laundry & 64 & 214 & 632 & 11 & 35 \\
\hline Hall 2 & 136 & 450 & 287 & 23 & 16 \\
\hline Bedroom 2 & 144 & 858 & 909 & 44 & 50 \\
\hline
\end{tabular}


WIC

Bedroom 3

Bath 2

Open To Below

Entire House

Other equip loads

Equip. @ 0.97 RSM

Latent cooling

TOTALS

\begin{tabular}{|c|c|c|c|c|c|}
\hline & $\begin{array}{r}38 \\
164 \\
151 \\
116\end{array}$ & $\begin{array}{r}29 \\
1077 \\
799 \\
532\end{array}$ & $\begin{array}{r}21 \\
1054 \\
501 \\
235\end{array}$ & $\begin{array}{r}1 \\
56 \\
41 \\
28\end{array}$ & $\begin{array}{r}1 \\
58 \\
28 \\
13\end{array}$ \\
\hline${ }_{\text {RSM }}{ }^{d}$ & 3690 & $\begin{array}{r}15400 \\
1222\end{array}$ & $\begin{array}{r}14359 \\
325 \\
14214 \\
0\end{array}$ & 797 & 797 \\
\hline & 3690 & 16622 & 14214 & 797 & 797 \\
\hline
\end{tabular}

Calculations approved by ACCA to meet all requirements of Manual J 8th Ed. 
